\title{
RELATION BETWEEN FRESHWATER FLOW AND SALINITY DISTRIBUTIONS IN THE ALAFIA RIVER, BULLFROG CREEK, AND HILLSBOROUGH BAY, FLORIDA
}

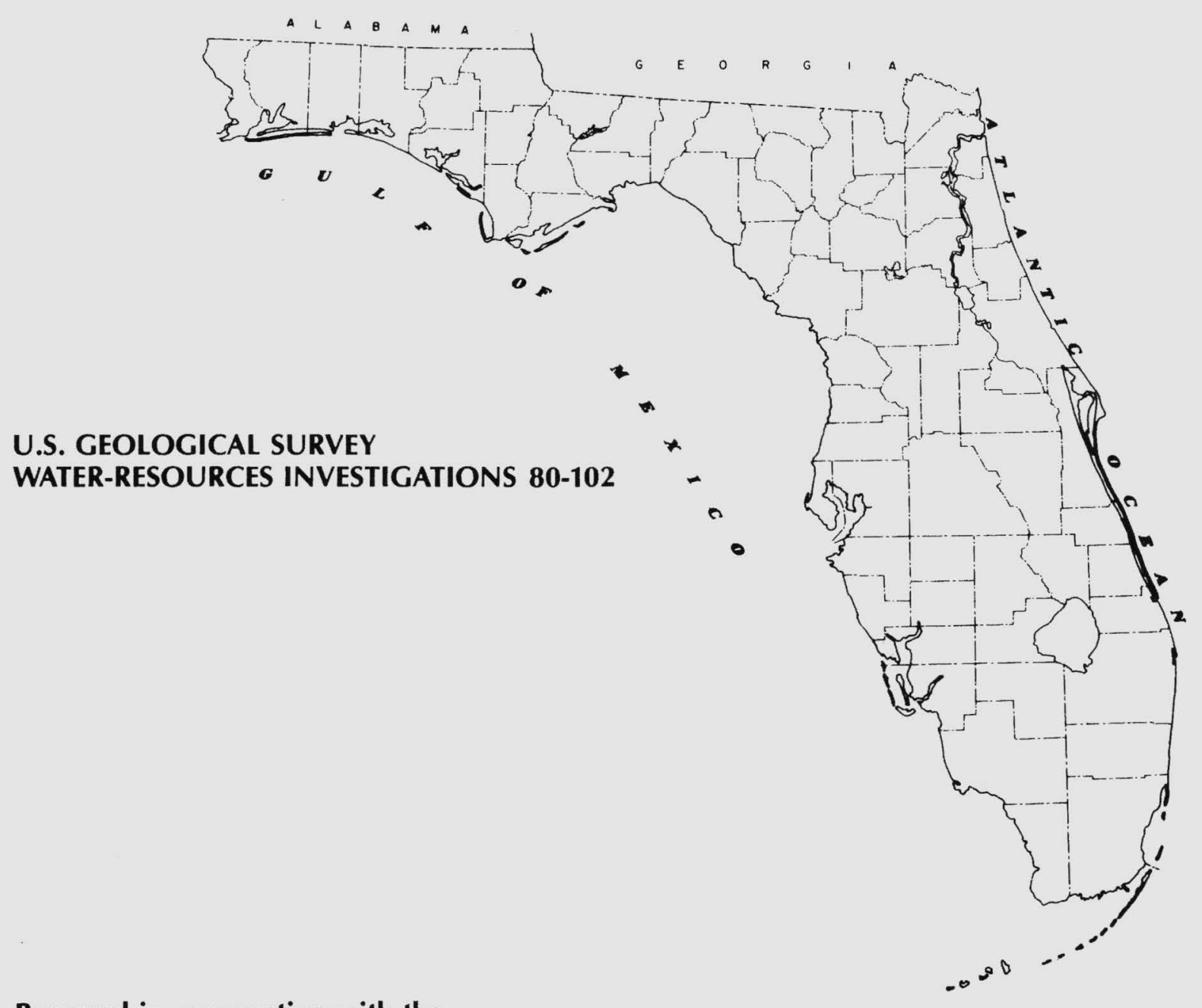

Prepared in cooperation with the SOUTHWEST FLORIDA WATER MANAGEMENT DISTRICT 


\section{REPORT DOCUMENTATION 1. REPORT NO. PAGE}

4. Title and Subtitle

RELATION BETWEEN FRESHWATER FLOW AND SALINITY DISTRIBUTIONS IN THE ALAFIA RIVER, BULLFROG CREEK, AND HILLSBOROUGH BAY, FLORIDA

7. Author(s)

R. F. Giovanne11i

9. Performing Organization Name and Address

U.S. Geological Survey, Water Resources Division

325 John Knox Road, Suite F-240

Tallahassee, Florida 32303

12. Sponsoring Organization Name and Address

U.S. Geological Survey, Water Resources Division

325 John Knox Road, Suite F-240

Tallahassee, Florida 32303

15. Supplementary Notes

Prepared in cooperation with the Southwest Florida Water Management District

16. Abstract (Limit: 200 words)

Data on streamflow, tide stage, specific conductance, and chloride concentrations were collected in the Alafia River and Bullfrog Creek to describe the salinity and physical characteristics of the saltwater wedge. The location of the saltwater-freshwater interface for both streams was described by multiple regression equations involving streamflow and tide stage. Low-flow frequency data were used with regression relations to show the effect of withdrawals of freshwater from the Alafia River on the location of the saltwater interface. Examples are presented without storage and with storage and minimum streamflow requirements. In every case, the effect of reductions in streamflow was upstream encroachment of saltwater.

Salinity in Hillsborough Bay in the vicinity of the Alafia River and Bullfrog Creek was evaluated using a salt-transport model for various freshwater inflow conditions. Model results indicate that freshwater inflow from these streams has the greatest effect on the salinity of areas closest to the mouth during periods of above average inflow.

17. Document Analysis a. Descriptors

*Salinity, *Saltwater-freshwater interface, Saltwater wedge, Freshwater inflow, Conductivity

b. Identifiers/Open-Ended Terms

*Florida, *Hillsborough County, Alafia River, Bullfrog Creek, Hillsborough Bay

c. COSATI Field/Group

18. Availability Statement

No restriction on distribution

\begin{tabular}{|c|c|}
\hline $\begin{array}{c}\text { 19. Security Class (This Report) } \\
\text { UNCLASSIFIED }\end{array}$ & $\begin{array}{l}\text { 21. No. of Pages } \\
68\end{array}$ \\
\hline $\begin{array}{c}\text { 20. Security Class (This Page) } \\
\text { UNCLASS IFIED }\end{array}$ & 22. Price \\
\hline
\end{tabular}


RELATION BETWEEN FRESHWATER FLOW AND SALINITY DISTRIBUTIONS IN

THE ALAFIA RIVER, BULLFROG CREEK, AND HILLSBOROUGH BAY, FLORIDA

By R. F. Giovannelli

U.S. GEOLOGICAL SURVEY

Water-Resources Investigations 80-102

Prepared in cooperation with the

SOUTHWEST FLORIDA WATER MANAGEMENT DISTRICT 
UNITED STATES DEPARTMENT OF THE INTERIOR

CECIL D. ANDRUS, Secretary

GEOLOGICAL SURVEY

H. William Menard, Director

For additional information write to:

U.S. Geological Survey

Water Resources Division

325 John Knox Road, Suite F-240

Tallahassee, Florida 32303 
Conversion factors -

Abstract - -

Introduction - -

Area description -_-_-_-_ 4

Physical processes in estuaries _- 6

Vertically stratified estuaries -_-_-_-_-_-_ 7

Vertically homogeneous estuaries -_-_-_-_ 7

Data collection -

Location and movement of the saltwater wedge -

Water-quality sampling -_-_-_- 11

Salinity and physical characteristics of the saltwater wedge - - -

Determination of salinity _-_ 13

Alafia River -

Bullfrog Creek -

Location of the saltwater interface -

Alafia River - predictive equation -_____-_ 25

Application of equation - 29

Bullfrog Creek - predictive equation -

Application of equation - 42

Salinity distributions in Hillsborough Bay -

Overall salinity ----_- 44

Salt-transport model -

Model description -- 50

Application to Hillsborough Bay -

Model results - 54

Summary and conclusions ...- 57

Selected references -_- 59

\section{ILLUSTRATIONS}

Figure 1. Map showing 1ocation of the Alafia River, Bullfrog Creek, and Hillsborough Bay - 3

2. Map showing location of gaging stations -

3. Diagram of a vertically stratified estuary -_-_-_-_-_-_-_ 8

4. Map showing locations of water-quality sampling sites ------- 12

5. Graphs showing relation between specific conductance, chloride concentration, and salinity for the Alafia River and Bullfrog Creek --_-_- 14

6. Graph showing variations of daily mean conductivity, discharge, and tide stage in the Alafia River --_-_-- 16

7. Graph showing mean discharge for the Alafia River at Lithia -- 18

8. Graphs showing typical semidiurnal tide cycle for Hillsborough Bay near the mouth of the Alafia River _- 19

9. Graph showing conductivity profiles in the Alafia River for various streamflow and tide-stage conditions -__-_-_-_ 21 


\section{ILLUSTRATIONS - Continued}

Figure 10. Graph showing variations in daily mean conductivity, discharge, and tide stage in Bullfrog Creek ----- 23

11. Graph showing conductivity profiles in Bullfrog Creek for various streamflow and tide-stage conditions --------------- 24

12. Graph showing relation between conductivity at Alafia River at Riverview and distance of the saltwater interface upstream from U.S. Highway 301 - 26

13. Graph showing comparison of daily mean locations of the saltwater interface in the Alafia Rives

14. Graph showing streambed elevations and location of the saltwater interface for zero discharge and selected tide-stage conditions in the Alafia River

15. Graph showing location of the saltwater interface in the Alafia River as a function of discharge for selected tidestage conditions

16. Graph showing magnitude and frequency of annual low flow of the Alafia River at Lithia

17. Graph showing the effect of withdrawals from the 2-year low flows on the location of the saltwater interface in the Alafia River

18. Graph showing draft-storage relation for 20-year low flows at the Alafia River at Lithia

19. Graph showing flow-duration curve for the Alafia River at Lithia for 1933-78

20. Graph showing tide-stage duration curves for Hillsborough Bay at the mouth of the Alafia River for September 1, 1978, to May 31, 1979 --

21. Map showing location and duration of the saltwater interface in the Alafia River for constant tide stage and variable streamflow -_-_-_-_-_-_- 40

22. Graph showing relation between location of the saltwater interface, discharge, and tide stage in Bullfrog Creek --.-- 43

23. Graph showing flow-duration curve for Bullfrog Creek near Wimauma for October 1956 to October 1958 and May 1977 to September 1979

24. Map showing location and duration of the saltwater interface in Bullfrog Creek for constant streamflow and variable tide stage

25. Graph showing variation in the average conductivity of Hillsborough Bay, total monthly mean freshwater inflow to Hillsborough Bay, and monthly mean inflow from the Alafia River, June 1972 through June 1976 


\section{ILLUSTRATIONS - Continued}

Page

Figure 26. Maps showing variation in conductivity distributions of Hillsborough Bay for periods of high, typical, and low freshwater inflow - 49

27. Map showing cell configuration and flow distribution across cell boundaries for average freshwater inflow conditions used in the salt-transport model

28. Graph showing relation between conductivity in selected model cells and freshwater inflow

TABLES

Table

1. Data collection sites

2. Conversions from conductivity to salinity

3. Summary of simulated conductivities in each model cell for selected freshwater inflow conditions

\section{CONVERSION FACTORS}

For readers who prefer to use SI (metric) units rather than inch-pound units, conversion factors for terms used in this report are listed below:

Multiply inch-pound unit

foot $(f t)$

mile (mi)

square mile $\left(\mathrm{mi}^{2}\right)$

cubic $_{3}$ foot per second $\left(\mathrm{ft}^{3} / \mathrm{s}\right)$

million gallons (Mga1)

million gallons per day

(Mgal/d)
By

0.3048

1.609

2.590

0.02832

3,785

0.04381

To obtain SI (metric) unit

meter (m)

kilometer $(\mathrm{km})$

square kilometer $\left(\mathrm{km}^{2}\right)$

cubic meter per second $\left(\mathrm{m}^{3} / \mathrm{s}\right)$

cubic meter $\left(\mathrm{m}^{3}\right)$

cubig meter per second $\left(\mathrm{m}^{3} / \mathrm{s}\right)$

National geodetic vertical datum of 1929 (NGVD of 1929)--A geodetic datum derived from a general adjustment of the first-order level nets of both the United States and Canada formerly called "mean sea level." Although the datum was derived from the average sea level over a period of many years at 26 tide stations along the Atlantic, Gulf of Mexico, and Pacific coasts, it does not necessarily represent local mean sea level at any particular place. 



\title{
RELATION BETWEEN FRESHWATER FLOW AND SALINITY DISTRIBUTIONS IN
}

THE ALAFIA RIVER, BULLFROG CREEK, AND HILLSBOROUGH BAY, FLORIDA

\author{
By R. F. Giovannelli
}

\section{ABSTRACT}

The Alafia River and Bullfrog Creek are coastal streams discharging into Hillsborough Bay that may be used as sources of freshwater. Reduction of streamflow will result in upstream movement of saltwater in both streams and increased salinity in Hillsborough Bay.

Data on streamflow, tide stage, specific conductance, and chloride concentration describe the salinity and physical characteristics of the saltwater wedge in the Alafia River and Bullfrog Creek. Flushing and large movement of saltwater were found to be controlled by large fluctuations in streamflow, whereas small, frequent movements of saltwater were a function of daily fluctuations of tide. Conductivity profiles indicate that increases in streamflow produce increased vertical stratification in both streams.

The location of the saltwater-freshwater interface in the Alafia River and Bullfrog Creek estuaries was described by multiple regression involving streamflow and tide stage. The average standard errors of estimate for the predictive equations ranged from 4.8 to 5.7 percent and the average multiple correlation coefficient was 0.97 . The Alafia River analysis extended from 4.6 miles above U.S. Highway 41 to the point of maximum saltwater encroachment at zero streamflow (10.5 miles above U.S. Highway 41 for a tide stage of 0.64 foot above the National Geodetic Vertical Datum of 1929). The Bullfrog Creek analysis extended from 0.25 to 2.9 miles above U.S. Highway 41.

Withdrawals of 35 and 105 cubic feet per second (25 and 75 percent of the 120-day, 2-year low flow) from the Alafia River without storage are predicted to cause an upstream movement of saltwater of 0.8 and 3.2 miles, respectively. To meet Southwest Florida Water Management District minimum streamflow requirements and to withdraw from the Alafia River on a regular basis during drought periods, storage is needed. Analysis for withdrawals with storage were made for full compliance and a 50 percent reduction in minimum streamflow requirements. The result of a 50 percent reduction in minimum streamflow requirements was an upstream movement of the daily mean location of the saltwater interface of 0.4 mile greater than the full compliance conditions. The analysis indicates that to meet a draft requirement of 24 million gallons per day through a 20-year drought, the minimum flow requirements would have to be reduced by approximately 50 percent.

A duration analysis for the Alafia River without withdrawals indicated that for mean tide conditions (0.64 foot above the National Geodetic Vertical Datum of 1929) the daily mean location of the saltwater interface would be 4.2 miles above U.S. Highway 41 seventy percent of the time and 8.2 miles 
above U.S. Highway 41 only 10 percent of the time. In Bullfrog Creek, a constant discharge of 18.5 cubic feet per second would place the daily mean location of the saltwater interface $0.8 \mathrm{mile}$ above U.S. Highway 41 ninety percent of the time and 1.9 miles above U.S. Highway 41 only 10 percent of the time.

Salinity in Hillsborough Bay varies with the volume and source of freshwater inflow. Salinity in the bay in the vicinity of the Alafia River and Bullfrog Creek was evaluated using a salt-transport model for freshwater inflow conditions ranging from 50 percent above average daily to 50 percent below the 30-day low flow. The maximum range in conductivity, 10,700 to 36,000 micromhos per centimeter, was in an area adjacent to the mouth of the Alafia River, whereas the conductivity of an area near the center of the bay ranged from 31,500 to 40,000 micromhos per centimeter. Model results indicate that freshwater inflow from the Alafia River and Bullfrog Creek has the greatest effect on areas closest to the mouth of these streams during periods of above average inflow.

\section{INTRODUCTION}

Use of freshwater in west-central Florida has been increasing steadily and is expected to continue to increase as population grows and development continues. To satisfy demands for freshwater, several streams in southern Hillsborough County may be considered as supply sources.

The Alafia River and Bullfrog Creek are coastal streams that flow through southern Hillsborough County and discharge into Hillsborough Bay (fig. 1). Diversion of water from these streams could be used to supply part of the growing needs of industry, agriculture, and municipalities in southern Hillsborough County.

Although the need for freshwater exists, it is essential that sufficient amounts of streamflow be maintained for preservation of a proper environmental balance. There is concern that saltwater intrusion and changes in salinity distributions of the Alafia River, Bullfrog Creek, and Hillsborough Bay would occur as a result of reduced freshwater inflow.

Salinity is a critical factor in the distribution and maintenance of many organisms in estuaries. Modifications to biological systems may take place because of changes in salinity distributions. These modifications could have long-term, detrimental effects on the ecological balance of estuarine systems. To properly manage and conserve available freshwater resources and to maintain an ecological balance, an understanding of the relation between saltwater movement and freshwater inflow to estuaries is needed.

This report provides results of studies evaluating changes in salinity distributions of the Alafia River, Bullfrog Creek, and Hillsborough Bay in the vicinity of those streams that are induced by fluctuations of freshwater inflow. Data on streamflows, tidal characteristics, specific 


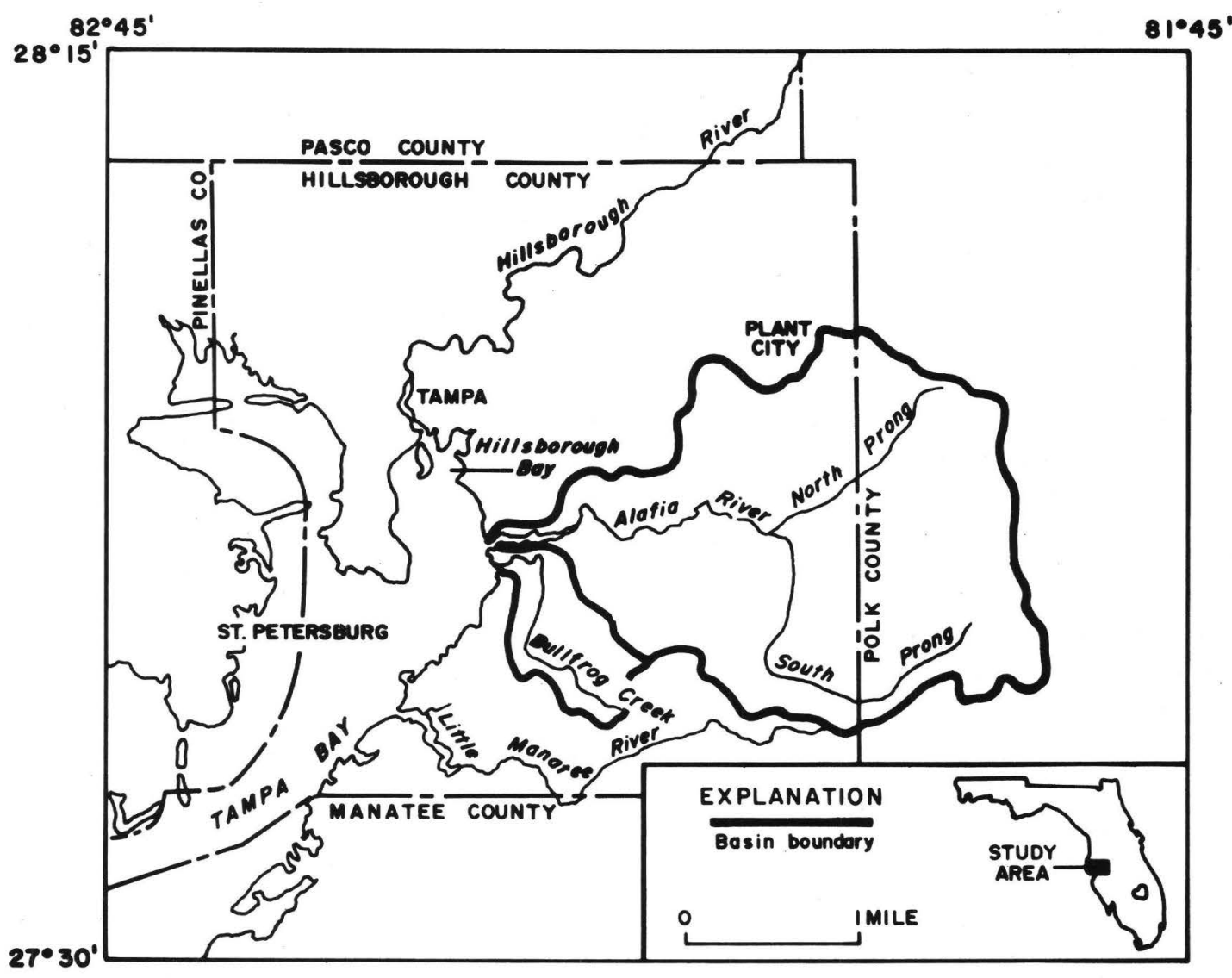

Figure 1.--Location of the Alafia River, Bullfrog Creek, and Hillsborough Bay. 
conductance, and chloride concentration are used to describe the distribution and movement of saltwater. Data on dissolved oxygen, temperature, and $\mathrm{pH}$ were collected to provide background information for use in a subsequent biological study. A conductivity of 1,000 micromhos per centimeter at $25^{\circ} \mathrm{C}$ (umho/cm) was selected to be the interface between freshwater and saltwater. Relations describing the daily mean location of the freshwater-saltwater interface in the Alafia River and Bullfrog Creek, as a function of streamflow and tide stage, were developed by regression analysis. Daily mean location of the interface is used to examine long-term changes in salinity for periods of several days, weeks, or greater rather than short-term changes of a day or less. This allows biological evaluations to be made on possible permanent changes that might occur from prolonged exposure to higher salinities.

These relations are used along with low flow frequency data to illustrate the effect of freshwater withdrawals on the daily mean location of the saltwater interface in the Alafia River. An example using streamflow storage and release rates is also included to show the results of reducing minimum streamflow requirements for the Alafia River. In addition, a duration analysis of the daily mean location of the saltwater interface is presented using streamflow and tide stage duration data and the predictive equations for both streams.

Sensitivity of salinity in Hillsborough Bay to fluctuations in freshwater inflow was evaluated using computer modeling techniques. Information on tidal circulation and freshwater inflow from the Alafia River and Bullfrog Creek was used in a segmented continuity salt-transport model that simulated salinity distributions for the bay in the vicinity of these streams.

\section{AREA DESCRIPTION}

The study area includes tidally affected reaches of the Alafia River and Bullfrog Creek and Hillsborough Bay in the vicinity of these streams (fig. 2). The Alafia River drains an area of about $410 \mathrm{mi}^{2}$ in Hillsborough and Polk Counties (fig. 1). The main stem of the river begins at the confluence of the North Prong and South Prong and flows westward, discharging into Hillsborough Bay. There are few natural lakes in the basin; however, many manmade lakes and open pits in the upper part of the basin have resulted from phosphate mining operations. Soils in the basin are sandy, and principal land uses are pasture, citrus, and phosphate mining. Throughout most of its length, the Alafia River flows in a well-defined channel through shallow, wooded valleys.

Normal tide fluctuations affect stages of the Alafia River for approximately 11 miles upstream from its mouth (fig. 2). There is a steep drop in streambed elevations in the vicinity of Bell Shoals Road. From Bell Shoals Road to U.S. Highway 301 the stream meanders in a narrow, deeply incised channel. Stream width ranges from about 45 to 460 feet and depth ranges from about 4 to 13 feet. From U.S. Highway 301 to U.S. Highway 41 the river flows nearly due west and is wider and shallower than the upstream reach. In this section of the stream, width ranges from about 350 to 1,500 feet and the depth varies from about 4 to 9 feet. U.S. Highway 41 is located 1.0 mile upstream from the mouth of the river. 


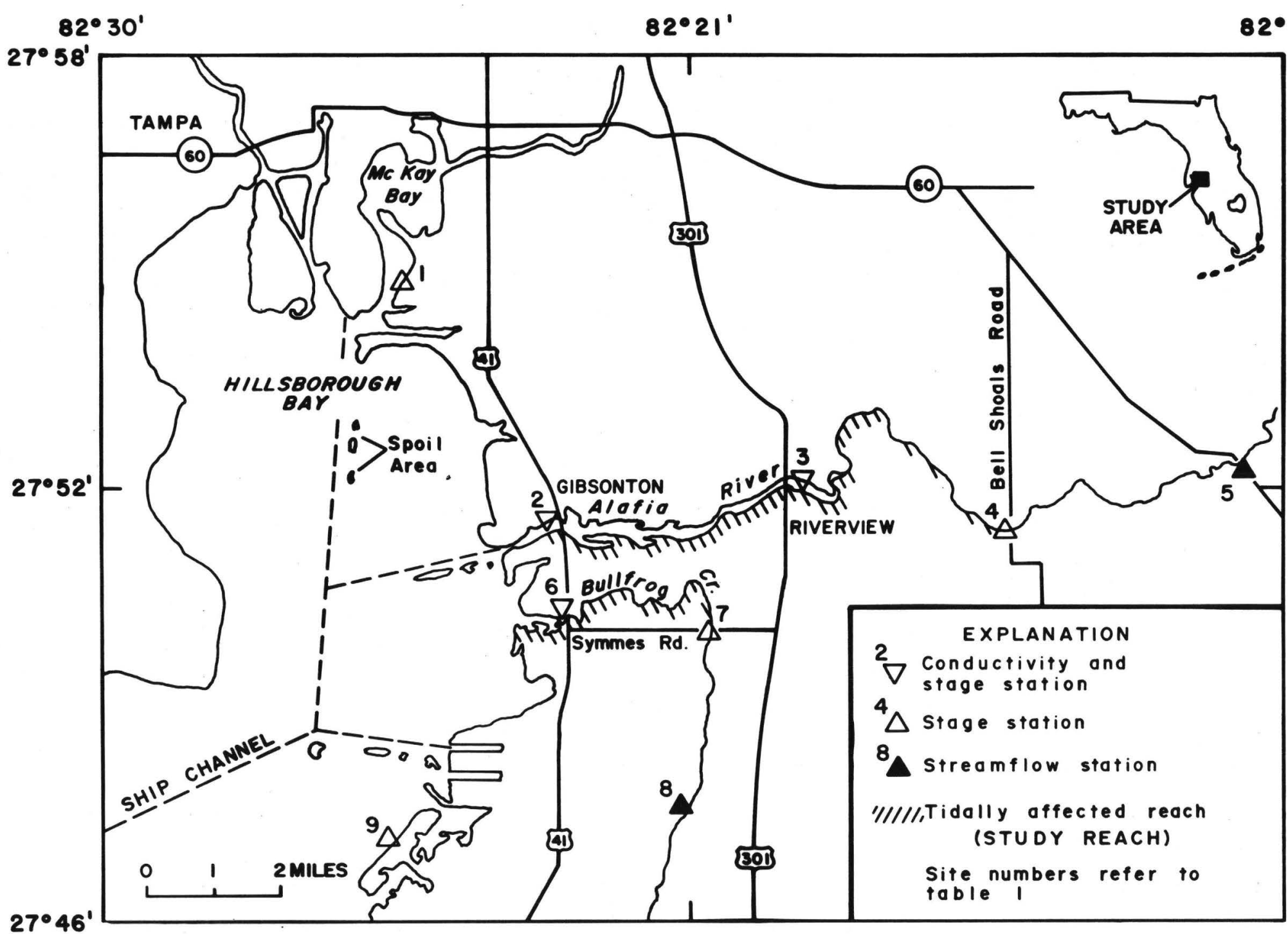

Figure 2.-Location of gaging stations. 
Bullfrog Creek drains an area of about $40 \mathrm{mi}^{2}$ in southeastern Hillsborough County (fig. 1). The headwaters of Bullfrog Creek are just north of Wimauma where the creek flows northward and westward, discharging into Hillsborough Bay 1 mile south of the Alafia River. The basin is composed mostly of sandy soil and has several small ponds and sinkholes. Bullfrog Creek has a fairly well-defined channel with a steep gradient in the upper basin, changing to a nearly flat gradient near the mouth. Normal tide fluctuations affect stream stage for approximately 5 miles upstream from its mouth (fig. 2). The tidally affected reach upstream from U.S. Highway 41 may be characterized as a meandering stream of narrow width and shallow depth. Channel width ranges between 30 and 195 feet and the depths range between 2 and 6 feet. U.S. Highway 41 is located 0.7 mile upstream from the mouth of Bullfrog Creek.

Hillsborough Bay is a subarea of Tampa Bay and is roughly 8 miles long and 4 miles wide ( $\mathrm{fig}$. 2). Its surface area is about $40 \mathrm{mi}^{2}$. At mean low water it has a volume of about 8,300 million $\mathrm{ft}^{3}$. Average depth of the bay at mean tide is 9 feet, and maximum natural depth is 28 feet. For the most part the bay is very shallow. Many large areas along the eastern and western shores have depths of 4 feet or less.

The bottom configuration of Hillsborough Bay has been altered by channel dredging and spoil placement. A ship channel runs north-south through the center of the bay from the mouth of McKay Bay to the mouth of Hillsborough Bay. The channel is 400 feet wide along most of its length and has an average depth of 34 feet. A side channel, 30 feet deep and 200 feet wide, leads to the Alafia River. Spoil areas have been created alongside these channels to dispose of dredged material.

Principal water uses in Hillsborough Bay are commerce (shipping), industrial cooling water, fishing, recreation, and shellfish production. Because of freshwater inflow and tidal exchanges of saline water, Hillsborough Bay and the tidally affected reaches of the Alafia River and Bullfrog Creek are classified as estuarine systems.

\section{PHYSICAL PROCESSES IN ESTUARIES}

An estuary may be defined as an area in which a freshwater inflow meets and interacts with saline tidal water. Estuarine waters have a composition that depends on the quantity and quality of freshwater and saline waters that are mixed and the manner in which they are mixed. Size and shape of estuaries, as well as tidal stage and fluctuations in freshwater inflow control circulation patterns and estuary classifications. Esutaries in this investigation are classified as vertically stratified or vertically homogeneous. 
Vertically Stratified Estuaries

Tidally affected reaches of the Alafla River and Bullfrog Creek are classified as vertically stratified estuaries. Saltwater intrusion occurs in the lower reaches of both streams and is caused by upstream movement of saltwater from Hillsborough Bay. Vertical stratification between the saltwater and freshwater is caused by density differences and results in the formation of a saltwater wedge as shown in figure 3. Because of its greater density, saltwater moves along the stream bottom, whereas the less dense freshwater tends to flow over the saltwater. The interface between freshwater and saltwater may be well defined or may exist as a zone of gradual transition. Even where it is well defined, some mixing between freshwater and saltwater takes place because of turbulence caused by channel obstructions, wind, or other factors.

The extent of saltwater intrusion and the type of interface that exists depend upon two primary factors. The first is the force created by downstream flow of freshwater. This force varies with streamflow and tends to push intruding saltwater downstream. High streamflow will flush saltwater from stream channels, whereas saltwater encroachment is greatest during periods of low flow. The second factor affecting location of the saltwater wedge is tide stage. When tide stage is greater than stream stage, a tidal force is created that drives a saltwater wave upstream. At the peak of the tide cycle, upstream movement of the saltwater wedge slows and eventually ceases. Saltwater movement reverses as the tide begins to fall. This pattern of movement of the saltwater wedge is repeated with each tide cycle. As a result, salinity in the tidally affected reaches of these streams varies both vertically and longitudinally along the stream channels.

Forces created by streamflow and tide stage have a combined effect on saltwater movement. Salinity distributions change with time in response to fluctuations in streamflow and tidal stage. The rate and direction of saltwater movement depends on the relative magnitude of these fluctuations.

Vertically Homogeneous Estuaries

Hillsborough Bay may be classified as a vertically homogeneous estuary as its salinity is constant from top to bottom at any point. Variations in salinity, however, occur longitudinally along the estuary; that is, water near the head of the estuary is fresher than that at the mouth. Basic circulation patterns are in the horizontal direction, but there is complete vertical mixing caused by wind, bottom configuration, and other factors. This circulation and mixing pattern is typical of shallow estuaries with large tidal flows and small freshwater inflows. In Hillsborough Bay, the surface area is very large with respect to its relatively shallow depths. In most cases, tide generated velocities are greater than mean freshwater inflow velocities. As a result, freshwater inflow has little effect on tidal flows and horizontal circulation. 


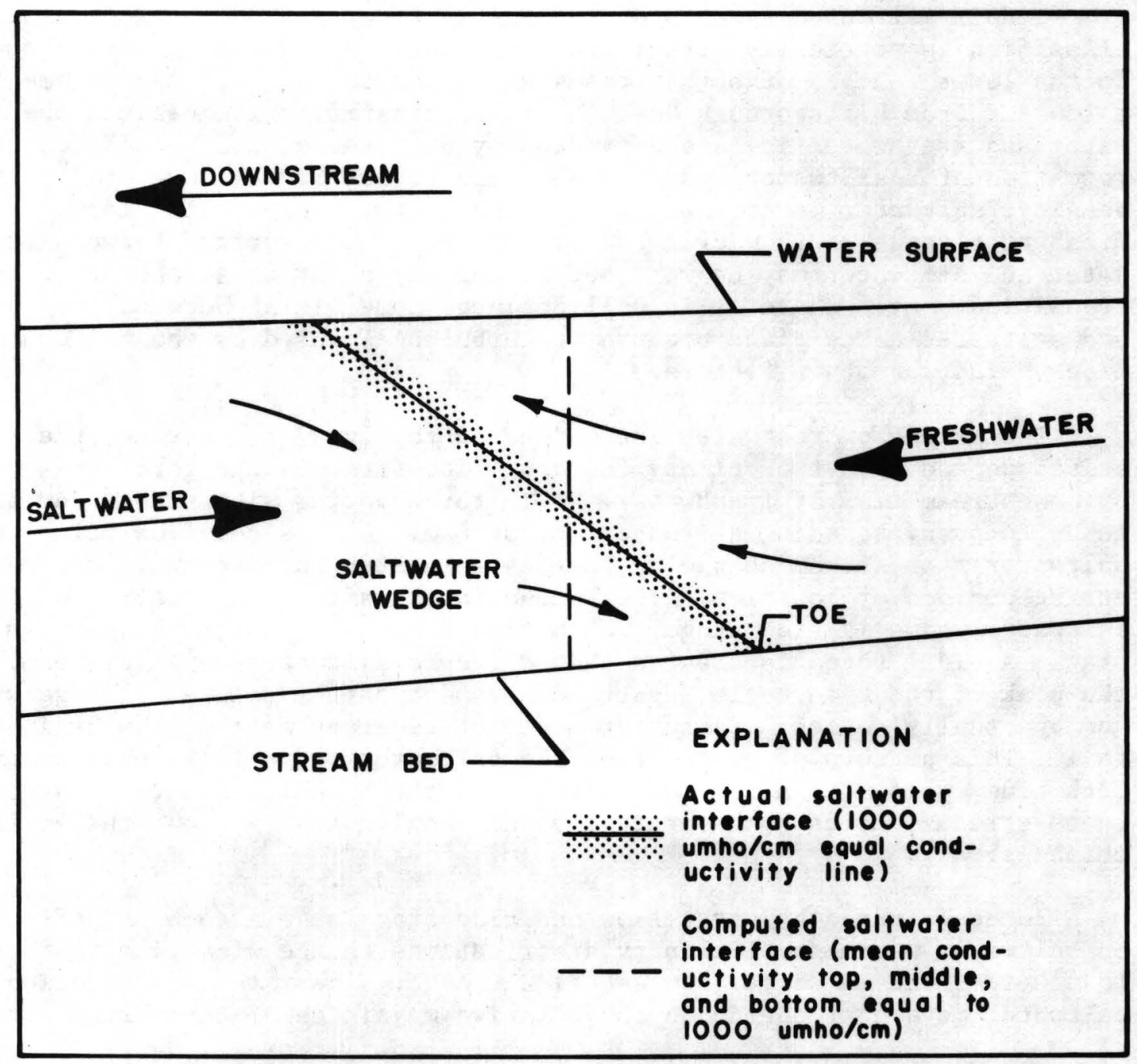

Figure 3.--Diagram of a vertically stratified estuary. 


\section{DATA COLLECTION}

A data-collection program was designed to obtain information for evaluating changes in salinity distributions of the Alafia River and Bullfrog Creek. Data collection began in April 1978 and continued through September 1979. The program involved collection of data that describe the salinity characteristics and movement of the saltwater wedge. Data were also collected to determine the location of the saltwater interface for various streamflow and tide-stage conditions.

\section{Location and Movement of the Saltwater Wedge}

The data network used to define movement of the saltwater wedge consisted of streamflow, tide stage, and conductivity stations (table 1 and fig. 2). Each station was equipped with instruments for recording data at 15-minute intervals.

Streamflow records used to determine freshwater inflow were obtained from existing gaging stations. Alafia River at Lithia (site 5, fig. 2) drains about 335 of the total $410 \mathrm{mi}^{2}$ area of the Alafia basin. Bullfrog Creek near Wimauma (site 8, fig. 2) drains about $29 \mathrm{mi}^{2}$ of the total 40 $\mathrm{mi}^{2}$ area of the Bullfrog Creek basin. These stations are just upstream from tidally affected reaches of each stream.

Tide-stage records were collected at two existing gaging stations in Hillsborough Bay and two stations installed near the mouth of each stream. Stations in Hillsborough Bay (sites 1 and 9, fig. 2) were not affected by streamflow from the Alafia River or Bullfrog Creek. Stations located near the mouths of the streams (sites 2 and 6, fig. 2) were used to determine time lag or change in amplitude of tide waves entering the streams. In addition, two stage recorders were installed at intermediate locations on the Alafia River (sites 3 and 4, fig. 2) and one on Bullfrog Creek (site 7 , fig. 2) to monitor changes in the characteristics of tidal waves in the stream channels.

Conductivity stations were installed on the Alafia River at U.S. Highway 41 at Gibsonton and near U.S. Highway 301 at Riverview (sites 2 and 3 , fig. 2). In addition, a temporary conductivity station was operated for a short period of time during low streamflow on the Alafia River at Bell Shoals Road near Riverview (site 4, fig. 2). This station was used in determining the maximum extent of saltwater encroachment during low streamflow. A conductivity station was also installed on Bullfrog Creek at U.S. Highway 41 at Gibsonton (site 6, fig. 2).

Specific conductance (conductivity), measured in micromhos per centimeter (umho/cm), was temperature compensated to $25^{\circ} \mathrm{C}$. The sensitivity range of the probes located at U.S. Highway 41 (sites 2 and 6, fig. 2) was 1,000 to 50,000 umho/ cm. The sensitivity range for the probe located 


\section{STREAMFLOW}

$\underline{\text { Station number }}$

02301500

02300700
Name

Alafia River at Lithia

Bullfrog Creek near Wimauma $\underline{\text { Site number }}^{1 /}$

5

8

TIDE STAGE

02301761

02300560

02300705

02300703

02301721

02301718

02301638
McKay Bay at Tampa

Tampa Bay near Ruskin (Apo11o Beach)

Bullfrog Creek at Gibsonton (U.S. Highway 41)

Bullfrog Creek near Riverview

Alafia River at Gibsonton (U.S. Highway 41)

Alafia River at Riverview (U.S. Highway 301)

Alafia River at Bell Shoals Road near Riverview
1

9

6

7

2

3

4

CONDUCTIVITY

Alafia River at Gibsonton (U.S. Highway 41) 2

Alafia River at Riverview (U.S. Highway 301) 3

Bullfrog Creek at Gibsonton (U.S. Highway 41) 6

1/ Refers to site shown on figure 2 . 
upstream from U.S. Highway 301 on the Alafia River (site 3, fig. 2) was from 1,000 to 30,000 umho/ cm. The temporary probe located at Bell Shoals Road (site 4, fig. 2) had a sensitivity range from 0 to $1,000 \mathrm{umho} / \mathrm{cm}$.

Supplemental conductivity data were collected in March, April, and May 1979 to determine location and movement of the saltwater interface for variuus tide-stage and streamflow conditions. A conductivity of 1,000 micromhos was selected to be the interface value between the freshwater and saltwater. A vertical line of $1,000 \mathrm{umho} / \mathrm{cm}$ average conductivity was determined by taking the mean of the top, middle, and bottom conductivity readings for a sample point, as shown in figure 3. This vertical line is the approximate location of the transition zone between freshwater and saltwater and is referred to, in this report, as the saltwater interface.

Conductivity was measured along the center of each stream until the saltwater interface was located. Movement of the saltwater interface was monitored. In several instances, upstream movement of the saltwater interface was monitored through a complete incoming tide cycle.

\section{Water-Quality Sampling}

Water-quality profile data were collected to identify the chemical and physical characteristics of the saltwater wedge in the Alafia River and Bullfrog Creek. Conductivity, temperature, $\mathrm{pH}$, and dissolved oxygen were measured monthly for a variety of tide-stage and streamflow conditions at sampling sites 1 through 28 , as shown in figure 4.

Physical parameters were measured using a portable, multiparameter, water-quality monitoring system. Measurements were made along the center line of the streams, 1 foot below the surface, at mid-depth (if the depth was greater than 6 feet), and at the stream bed. In addition, a surface sample for determination of chloride concentration was collected at each sampling site.

Water-quality data for Hillsborough Bay used in this study were taken from Goetz and Goodwin (1980). Available data include chloride concentration, conductivity, $\mathrm{pH}$, temperature, turbidity, and dissolved oxygen collected from June 1972 to June 1976 at sampling sites 29 through 38 , in figure 4.

\section{SALINITY AND PHYSICAL CHARACTERISTICS OF THE SALTWATER WEDGE}

The salinity and physical characteristics of estuarine water is representative of the freshwater and saltwater entering and mixing within its boundaries. Salinity of water is defined as the total concentration of ionic components. In seawater these components are primarily composed of dissolved salts for which chloride is predominant. Salinity is usually expressed in parts per thousand (ppt) or grams of dissolved salts per kilogram of seawater. Salinity of ocean water generally ranges between 33 and 38 ppt with the average being about 35 ppt. The average salinity of freshwater ranges between 0.065 and $0.30 \mathrm{ppt}$. 


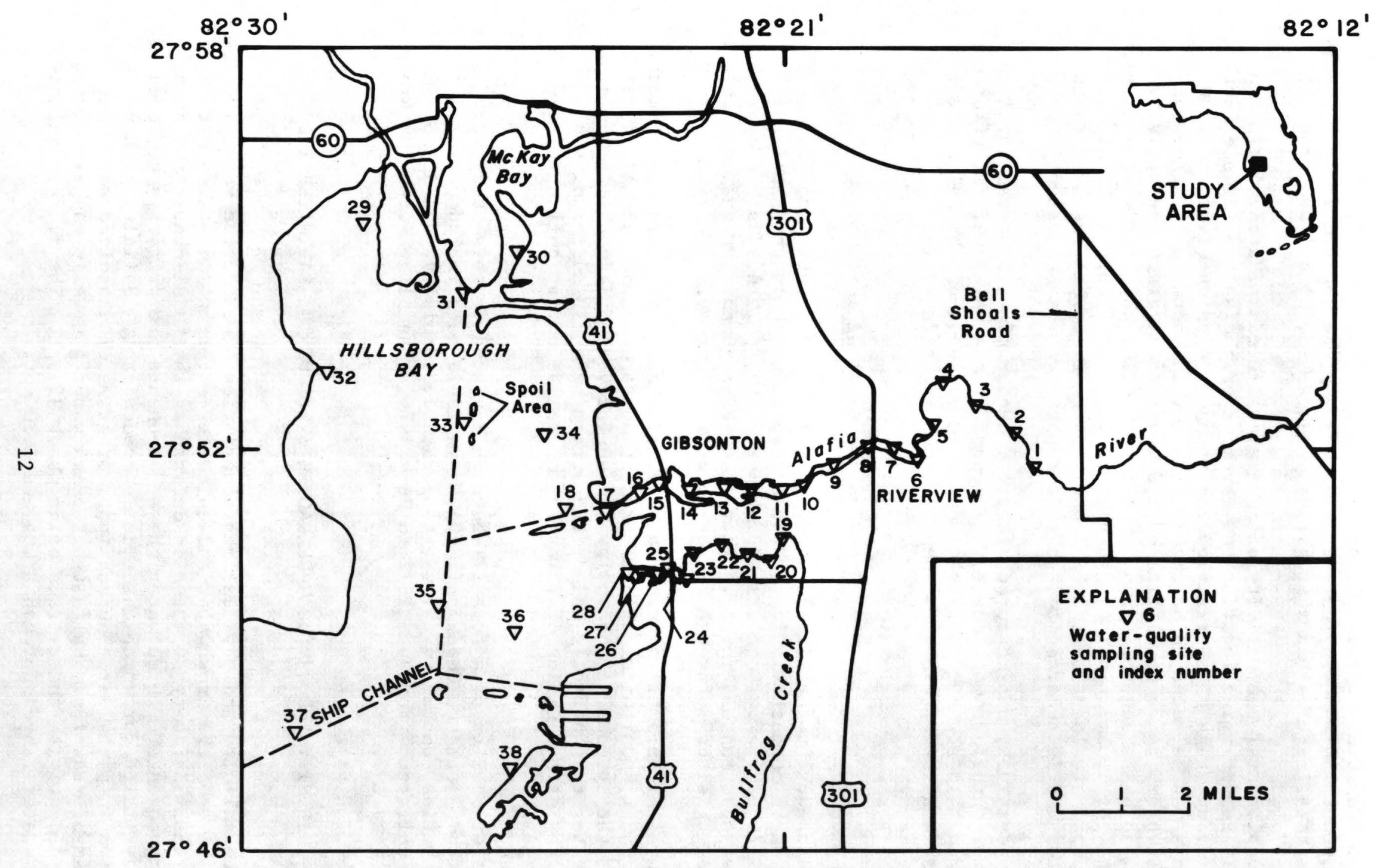

Figure 4.--Locations of water-quality sampling sites. 


\section{Determination of Salinity}

The direct determination of salinity is very difficult, therefore alternate methods of indicating salinity have been developed. Because chloride is the predominant anion in seawater, it is possible to estimate salinity by measuring chloride concentration. The relations between chloride concentration and salinity, as based on determinations from a variety of seawater samples (Riley, 1965, p. 76), is given below;

$$
S=1.805(\mathrm{C} 1)+0.03
$$

where $\quad \mathbf{S}=$ Salinity, in parts per thousand;

Cl $=$ Chloride concentration, in parts per thousand.

Another method used to measure the amount of ionized material in water is by determination of electrical conductance. Specific conductance (conductivity) is defined as the ability of water to transmit an electrical current and is proportional to the amount of dissolved salts (ions) in the water. The greater the salinity or chloride concentration, the greater the conductivity. Graphs showing the relations between conductivity, chloride concentration, and salinity for the Alafia River and Bullfrog Creek are shown in figure 5. At chloride concentrations of 250 milligrams per liter (mg/L) and greater, the scatter in the points is small due to the predominant influence of seawater. The chemical composition of seawater is fairly constant throughout the world. This accounts for the stability of the relation at higher chloride concentrations. At concentrations less than $250 \mathrm{mg} / \mathrm{L}$, there is a slight scatter due to variations in ion components of freshwater.

Graphs, shown in figure 5, and equation 1 illustrate the interrelations between salinity, chloride concentration, and conductivity. For this study, conductivity was used as an indicator of salinity because of the relative ease and precision with which conductivity could be determined. In many other applications the use of salinity would be more suitable, therefore, a table for converting conductivity to salinity based on normal seawater composition is shown in table 2 .

\section{Alafia River}

The variations of conductivity, tide stage, and streamflow for the Alafia River are shown graphically in figure 6. Data plotted are daily mean values for the period from September 1, 1978, through May 31, 1979. Due to the distance of the streamflow gage from the study reach, discharge data are lagged 1 day to allow for traveltime. Although travel time varies with the rate of discharge, for the purpose of this illustration an.average lag of 1 day was determined to be sufficient. Daily mean discharge during the period shown ranged from 76 to $2,180 \mathrm{ft}^{3} / \mathrm{s}$. 


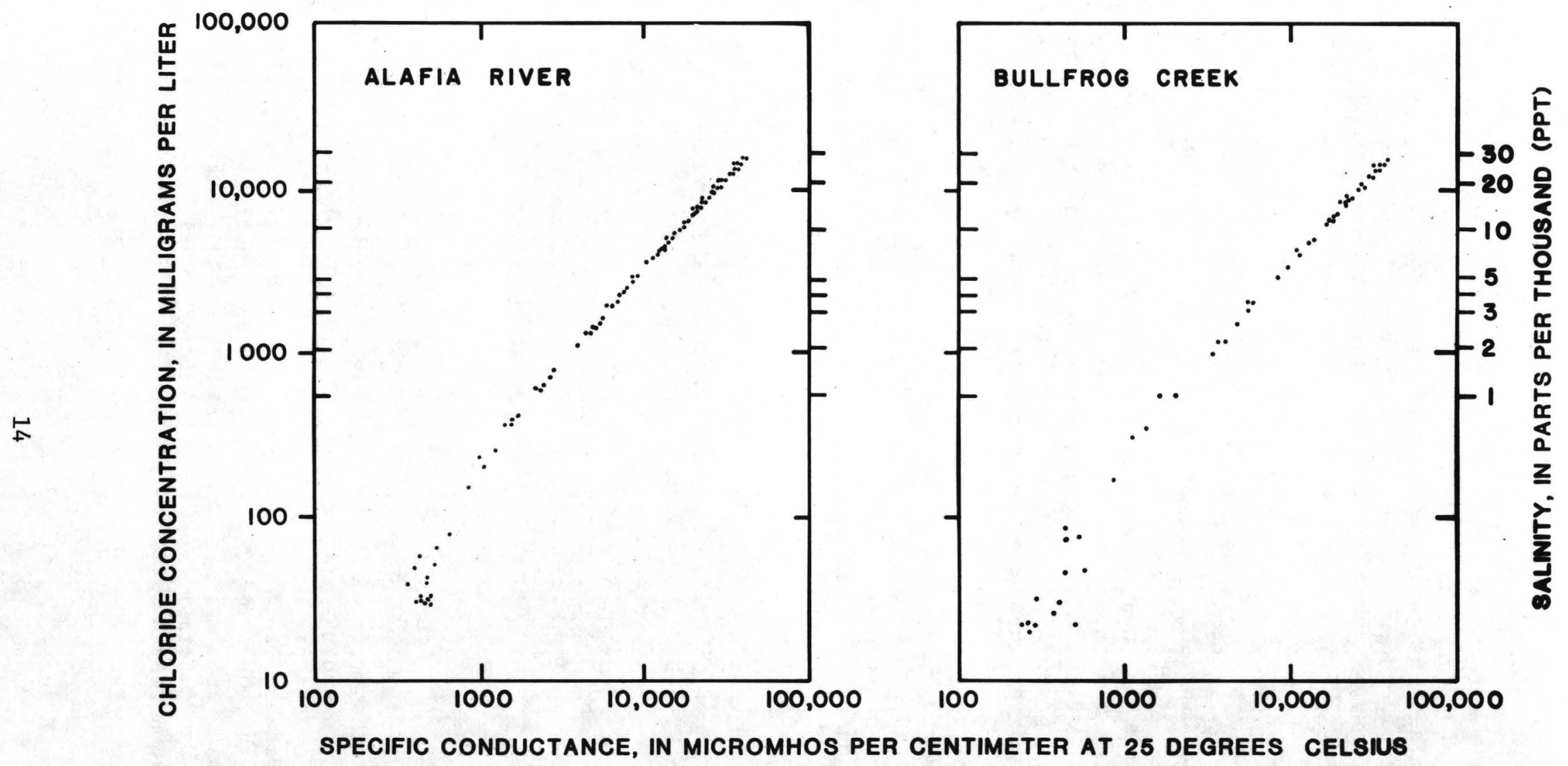

Figure 5.--Relation between specific conductance, chloride concentration, and salinity for the Alafia River and Bullfrog Creek. 
Table 2.--Conversions from conductivity to salinity

(Modified from Tiphane, 1962)

Conductivity, in micromhos per centimeter at $25^{\circ} \mathrm{C}$

\begin{tabular}{|c|c|}
\hline 1,000 & 0.55 \\
\hline 2,000 & 1.10 \\
\hline 3,000 & 1.59 \\
\hline 4,000 & 2.20 \\
\hline 5,000 & 2.70 \\
\hline 6,000 & 3.25 \\
\hline 7,000 & 3.80 \\
\hline 8,000 & 4.45 \\
\hline 9,000 & 5.00 \\
\hline 10,000 & 5.60 \\
\hline 12,000 & 6.90 \\
\hline 14,000 & 8.10 \\
\hline 16,000 & 9.40 \\
\hline 18,000 & 10.60 \\
\hline 20,000 & 11.95 \\
\hline 22,000 & 13.25 \\
\hline 24,000 & 14.50 \\
\hline 26,000 & 15.80 \\
\hline 28,000 & 17.20 \\
\hline 30,000 & 18.60 \\
\hline 35,000 & 22.00 \\
\hline 40,000 & 25.65 \\
\hline 45,000 & 29.15 \\
\hline 50,000 & 32.70 \\
\hline
\end{tabular}

Salinity, in parts per thousand

0.55

.10

1.59

.20

2.70

.25

.80

.45

.00

.60

6.90

.10

9.40

0.60

1.95

3.25

4.50

5.80

17.20

8.60

22.00

5.65

29.15

2.70 


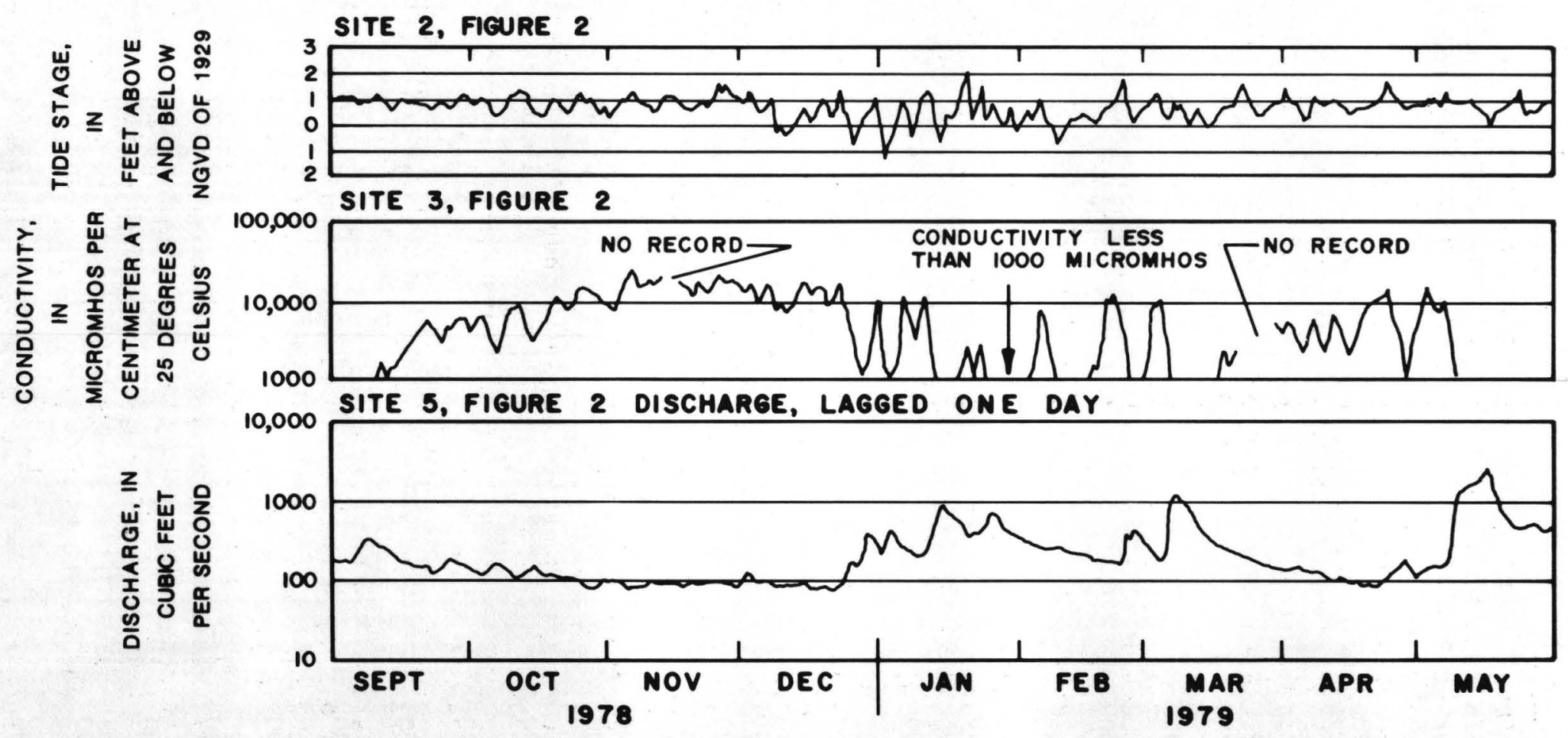

Figure 6.--Variations of daily mean conductivity, discharge, and tide stage in the Alafia River. 
Mean monthly discharge varies in response to rainfall. Normally, highest discharges occur in late summer and early fall and lowest discharges occur in winter and spring. Mean monthly discharges for the Alafia River at Lithia streamflow station (site 5, fig. 2) are shown in figure 7 . Mean daily discharge for the period of record (46 years) is $364 \mathrm{ft} / \mathrm{s}$. As indicated in figure 7, streamflow was below the daily average for most of the period from September 1978 to April 1979. Due to a heavy rainstorm in May 1979 and greater than normal rainfall for the remainder of the 1979 water year, streamflow remained near or above the daily average from May 1979 to September 1979. Because saltwater enchroachment is greatest during periods of below average streamflow, only the record shown in figure 6 was examined.

Tides in Hillsborough Bay are predominantly semidiurnal with some diurnal and mixed tides. A typical semidiurnal tide cycle near the mouth of the Alafia River (site 2, fig. 2) is shown in figure 8. Mean tide level (MTL) for the period September 1978 to May 1979 was 0.64 foot above the National Geodetic Vertical Datum of 1929. The maximum instantaneous high water (HHW) was 3.28 feet above the datum, and the minimum low water (LLW) was 2.67 feet below the datum. Tidal range, or the range from LLW to HHW during one tide cycle, was from 1.45 to 3.71 feet, and the mean tidal range was 2.45 feet.

Tide levels and ranges vary seasonally and monthly with phases of the moon. Tide levels are slightly higher in the summer and fall than in the spring and winter. Wind force and direction also affect tide levels. Southerly winds tend to push water into the bay raising tide levels, whereas northerly winds tend to push water out of the bay lowering tide levels. Tide levels in the bay directly affect the movement of tidal waves up the Alafia River. The time required for a typical tidal peak to travel up the tidally affected reach of the Alafia River is about 1 to 2 hours.

A strong correlation exists between conductivity and streamflow and tide stage. Changes in conductivity in the Alafia River are directly proportional to changes in tide stage and inversely proportional to changes in streamflow. The period and pattern of tides and streamflow are different. The effects of tides result in daily cyclic fluctuations in salinity, whereas the effects of streamflow are not cyclic but reflect a less predictable rainfall pattern. Streamflow has an overiding effect on salinity during periods of high discharge. Variations in conductivity at site 3 (fig. 2) for the Alafia River are shown in figure 6. For the period from early September to late October, streamflow in the Alafia River was generally declining while conductivity was steadily increasing. From early November to late December, streamflow was uniform except for small daily fluctuations, and conductivity remained constant except for fluctuations that were almost entirely tide induced. Beginning in late December and continuing for the remainder of the period, the large fluctuations in conductivity were almost entirely due to changes in streamflow.

Conductivity at the reference site (site 3, fig. 2) ranged from 300 to $30,000 \mathrm{umho} / \mathrm{cm}$. During the period September 1978 to May 1979 , the reach upstream of U.S. Highway 301 was flushed with freshwater (conductivity less than 1,000 umho/cm) for periods of from several hours to 22 days. For normal tide-stage conditions, an above average discharge produces freshwater conditions in this reach of the river. 


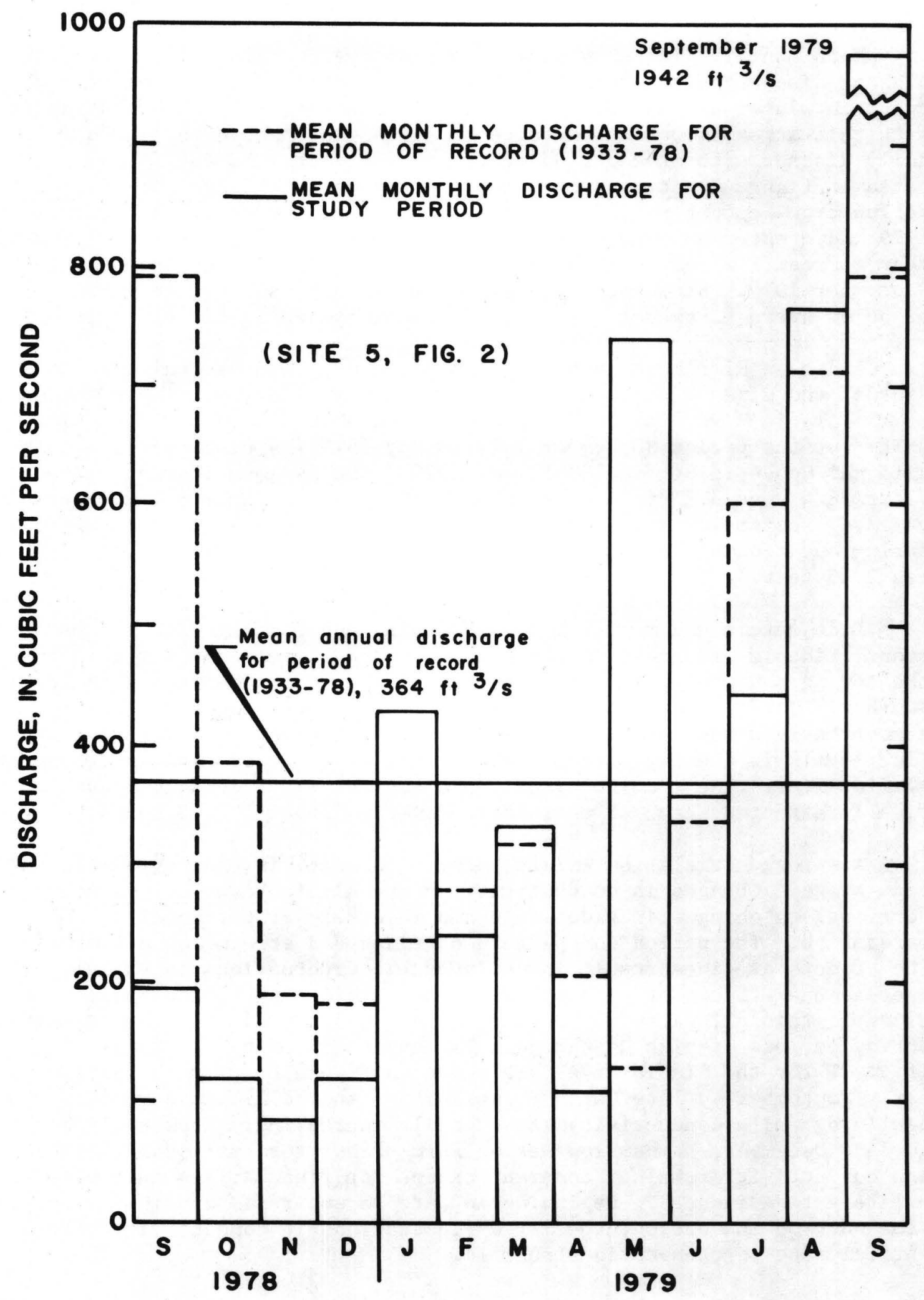

Figure 7.--Mean discharge for the Alafia River at Lithia. 


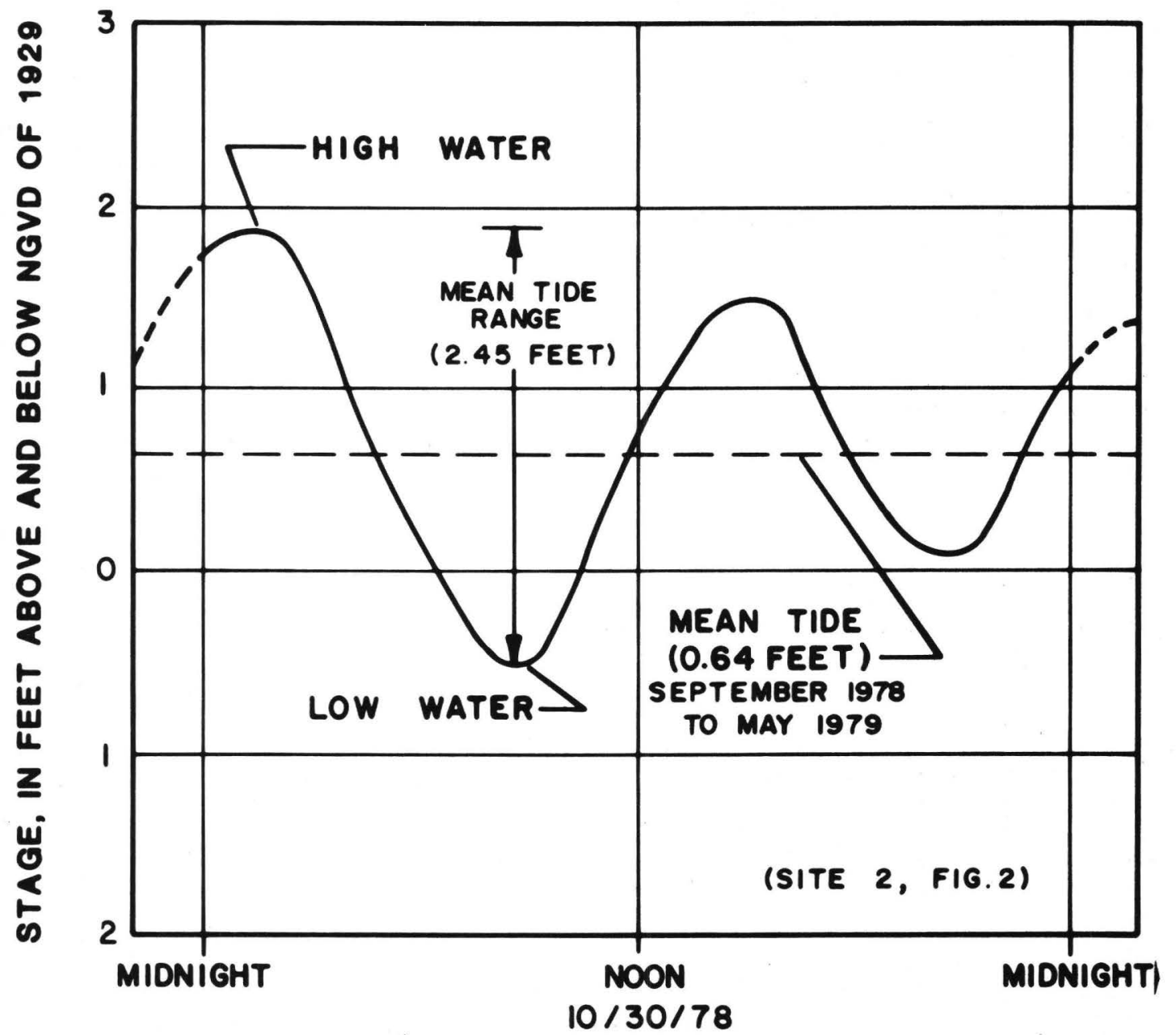

Figure 8.--Typical semidiurnal tide cycle for Hillsborough Bay near the mouth of the Alafia River. 
The section of the Alafia River from U.S. Highway 301 to the mouth experienced less frequent flushing than the upstream section because of its proximity to the bay. Fluctuations in conductivity at U.S. Highway 41 (site 2 , fig. 2) ranged from 3,000 to $42,000 \mathrm{umho} / \mathrm{cm}$. Freshwater conditions in this reach occur only during periods of high streamflow or during periods of above average streamflow when tides are below normal. There were several periods from mid-January to late May 1979 when salinities were reduced to near freshwater conditions by above average streamflow. Complete freshwater flushing of the entire study reach, however, did not occur from September 1978 to May 1979. In late September 1979, following several months of above avȩrage rainfall, mean daily discharge in the Alafia River rose above 3,500 $\mathrm{ft}^{3} / \mathrm{s}$. This produced freshwater conditions at U.S. Highway 41 for several days. A mean daily discharge of $3,500 \mathrm{ft} / \mathrm{s}$ has an approximate 2-year recurrence interval; that is, the average time within which a discharge of this magnitude will be exceeded once. As streamflow began to decline, conductivity rose and salinity returned to normal levels.

Information on the upstream movement of saltwater was obtained from a conductivity recorder located at Bell Shoals Road (site 4, fig. 2) and operated during a period of low streamflow from April 4, 197\%, to May 2, 1979. Daily discharge for this period ranged from 79 to $175 \mathrm{ft}^{3} / \mathrm{s}$, and mean daily tides ranged from 0.03 feet below to 1.50 feet above NGVD of 1929 . The maximum HHW for this period was 2.76 feet above the datum. At no time during this period was conductivity as high as $1,000 \mathrm{umho} / \mathrm{cm}$.

Conductivity profiles of the Alafia River are shown in figure 9 for various streamflow and tide conditions. These profiles show vertical salinity distributions and the general location of equal-conductivity lines. Daily discharges shown are for the day prior to the sampling date to allow for a lag of 1 day. The tide stage shown is the mean stage at the mouth of the Alafia River during the time of sampling. Streambed elevations were determined using water-surface elevations and depths at each sampling point. Approximate locations of the $1,000,5,000,10,000$, 20,000 , and 30,000 umho/ cm lines were determined by linear interpolation between sampling points.

Conductivity profiles are shown for various combinations of streamflow and tide stage. Maximum saltwater encroachment occurs for low streamflow and high-tide conditions (fig. 9A). The intersection of the $1,000 \mathrm{umho} / \mathrm{cm}$ conductivity line with the streambed is approximately 9 miles upstream from U.S. Highway 41. For low tide and high streamflow conditions (fig. 9D) most of the Alafia River has been flushed by freshwater, and the 1,000 umho/ cm line is approximately 1.6 miles upstream of U.S. Highway 41 . As shown in figure 9C, vertical salinity differences increase as streamflow and tide stage increase. This increased stratification is caused by a decrease in vertical mixing with freshwater overriding the saltwater. 
November 13, 1978

Mean tide teog for sompling poriod $=1.10$ foet obove NGVD meen daily discherge $=85$ cubic feet per second

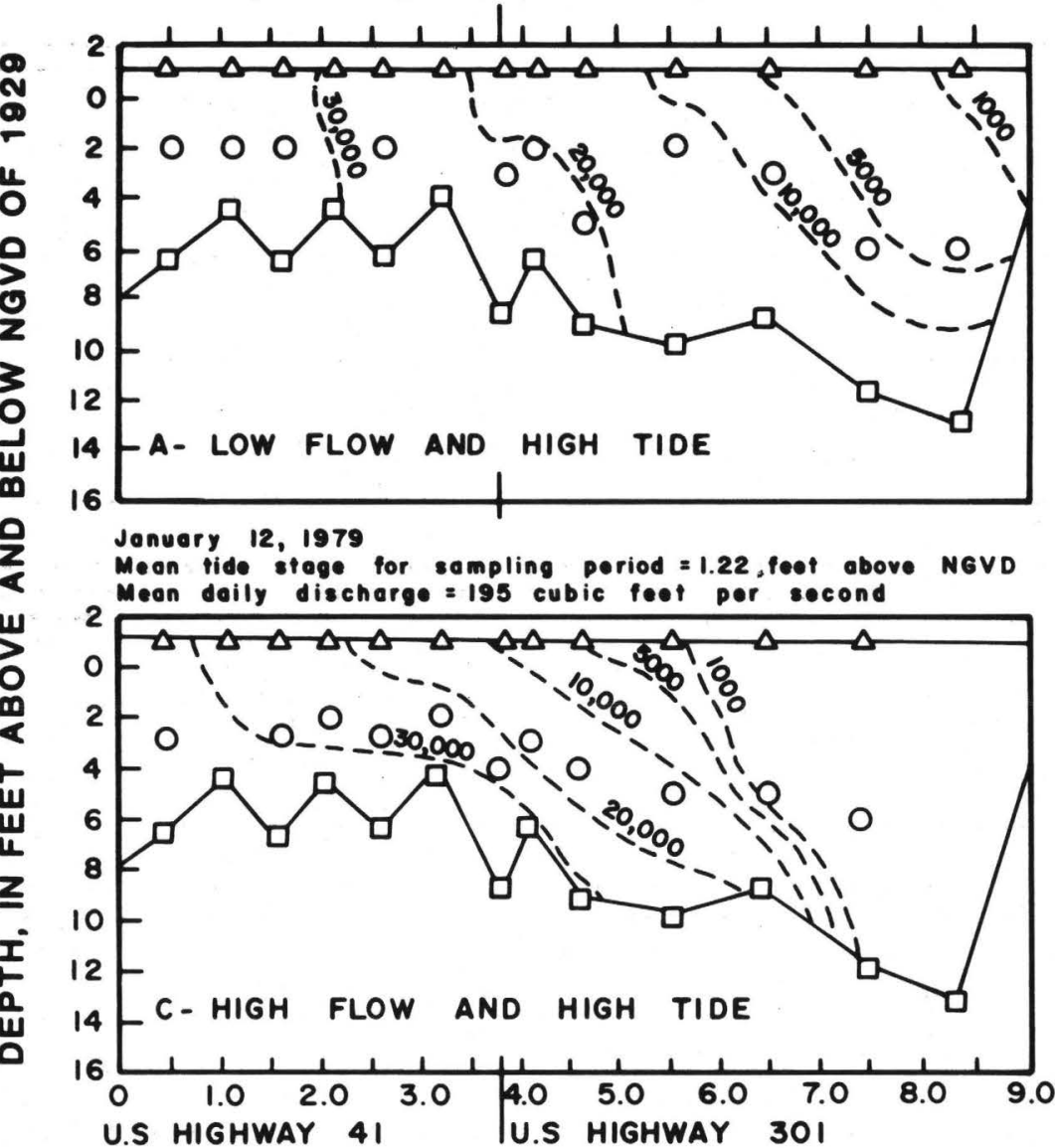

Oetober 24, 1978

for selow $=0.23$ feet below NGV Meen daily discherge $=99$ cubic foet per second

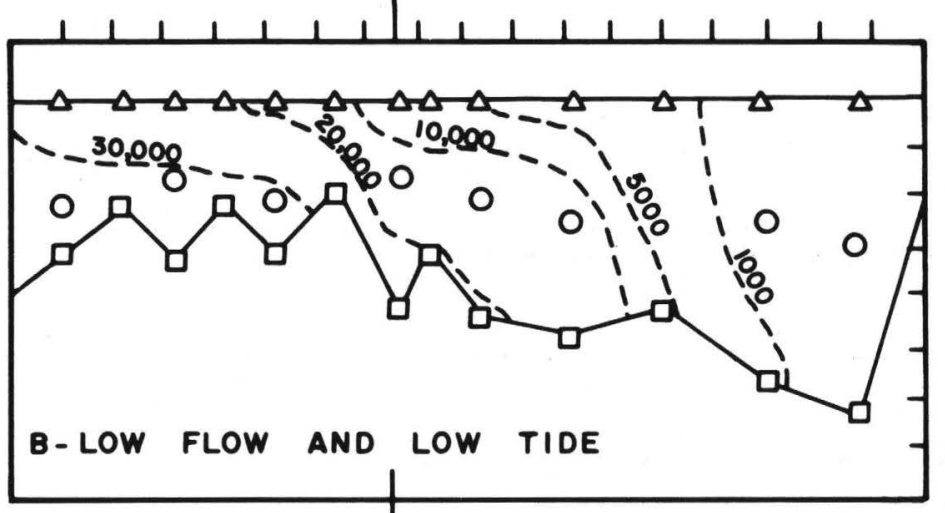

Januery 26, 1979

Mean tide sage for sompling period $=1.16$ feet below NGVD Mean daily discharge $=667$ cubic feet per second

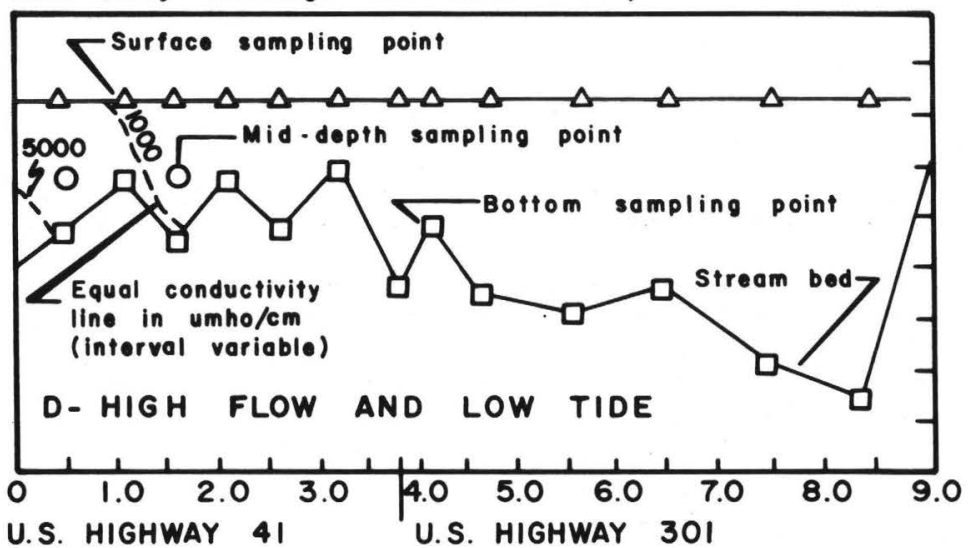

DISTANCE ABOVE U.S. HIGHWAY 41, IN MILES

Figure 9.--Conductivity profiles in the Alafia River for various streamflow and tide-stage conditions. 


\section{Bu11frog Creek}

Relations between streamflow, tide stage, and conductivity for Bullfrog Creek for the period from September 1978 to May 1979 are shown in figure 10. Shown are daily mean values of conductivity and tide stage at U.S. Highway 41 (site 6, fig. 2) and discharge near Wimauma (site 8, fig. 2).

Discharge during the period ranged from 3.7 to $644 \mathrm{ft}^{3} / \mathrm{s}$. Mean daily discharge for the periods of reçrd, October 1956 to October 1958 and May 1977 to September 1979, is $37 \mathrm{ft} / \mathrm{s}$. Discharge during most of the study period was well below this average. Bullfrog Creek reacts differently to rainfall than does the Alafia River. Hydrograph peaks (fig. 10) are sharper, and the stream quickly returns to base flow conditions. Tidal conditions in Bullfrog Creek are very similar to those for the Alafia River.

As shown in figure 10, fluctuations in conductivity exhibit a strong correlation with fluctuations in streamflow and tide stage. For the period, September 1978 to May 1979, conductivity at U.S. Highway 41 ranged from 300 to 42,000 umho/ cm. This wide range in conductivity is due to proximity to the bay and the variability of streamflow.

Salinity in Bullfrog Creek is very sensitive to changes in tide stage and streamflow. During periods of low tide, a relatively small discharge tends to flush saltwater from the study reach. During periods of high tide, however, flushing occurs only when streamflow is high. The entire Bullfrog Creek study reach was flushed several times during the period from September 1978 to May 1979. These periods of freshwater conditions lasted only a few days due to the rapid decrease in streamflow, For normal tide conditions, a sustained discharge of approximately $70 \mathrm{ft}^{3} / \mathrm{s}$ would completely flush saltwater from the study reach.

Conductivity profiles of Bullfrog Creek are shown in figure 11 for a variety of tide and streamflow conditions. These profiles show vertical salinity distributions and the location of the $1,000,5,000,10,000,20,000$, and 30,000 umho/cm equal-conductivity lines. Daily mean discharges listed in figure 11 are for the date of sampling. The tide stage shown is the mean stage at the mouth of Bullfrog Creek during the time of sampling.

The maximum saltwater encroachment occurred during low flow and high tide conditions ( $\mathrm{fig} .11 \mathrm{~A}$ ) and the $1,000 \mathrm{umho} / \mathrm{cm}$ conductivity line is about 3 miles upstream from U.S. Highway 41. For high flow and low tide conditions (fig. 11D), freshwater prevails and the 1,000 umho/ cm conductivity line is about 0.7 mile upstream from U.S. Highway 41. Generally, Bullfrog Creek had little vertical stratification (fig. 11). This resulted from the small volume of freshwater inflow and the shallow depths that allow for vertical mixing. Differences in discharges for the examples shown in figure 11 are small, yet the range in movement of the saltwater wedge is large. This indicates that movement of the saltwater wedge in Bullfrog Creek is relatively sensitive to fluctuations in streamflow. 
SITE 6, FIGURE 2
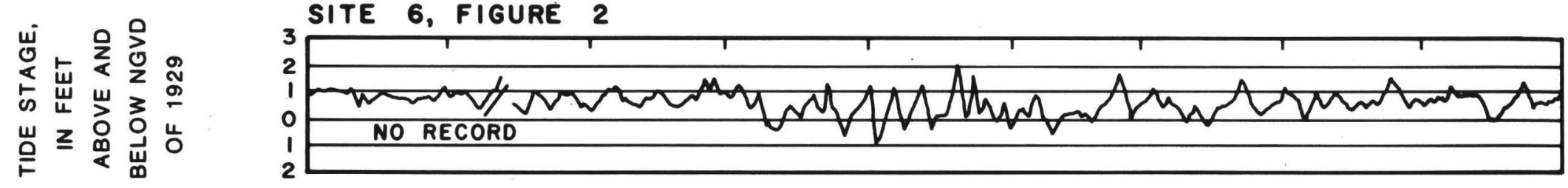

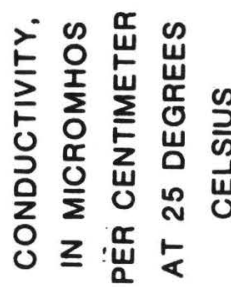

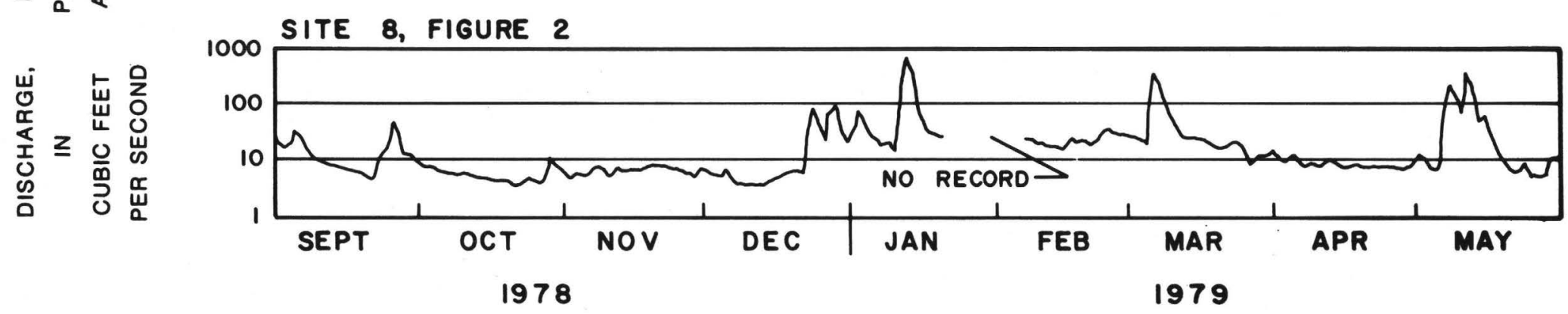

Figure 10.--Variations in daily mean conductivity, discharge, and tide stage in Bullfrog Creek. 
October 25, 1978

Mean tide stoge for sampling period $=1.04$ feet above NGVD

Meon daily discharge $=4.9$ cubic feet per second

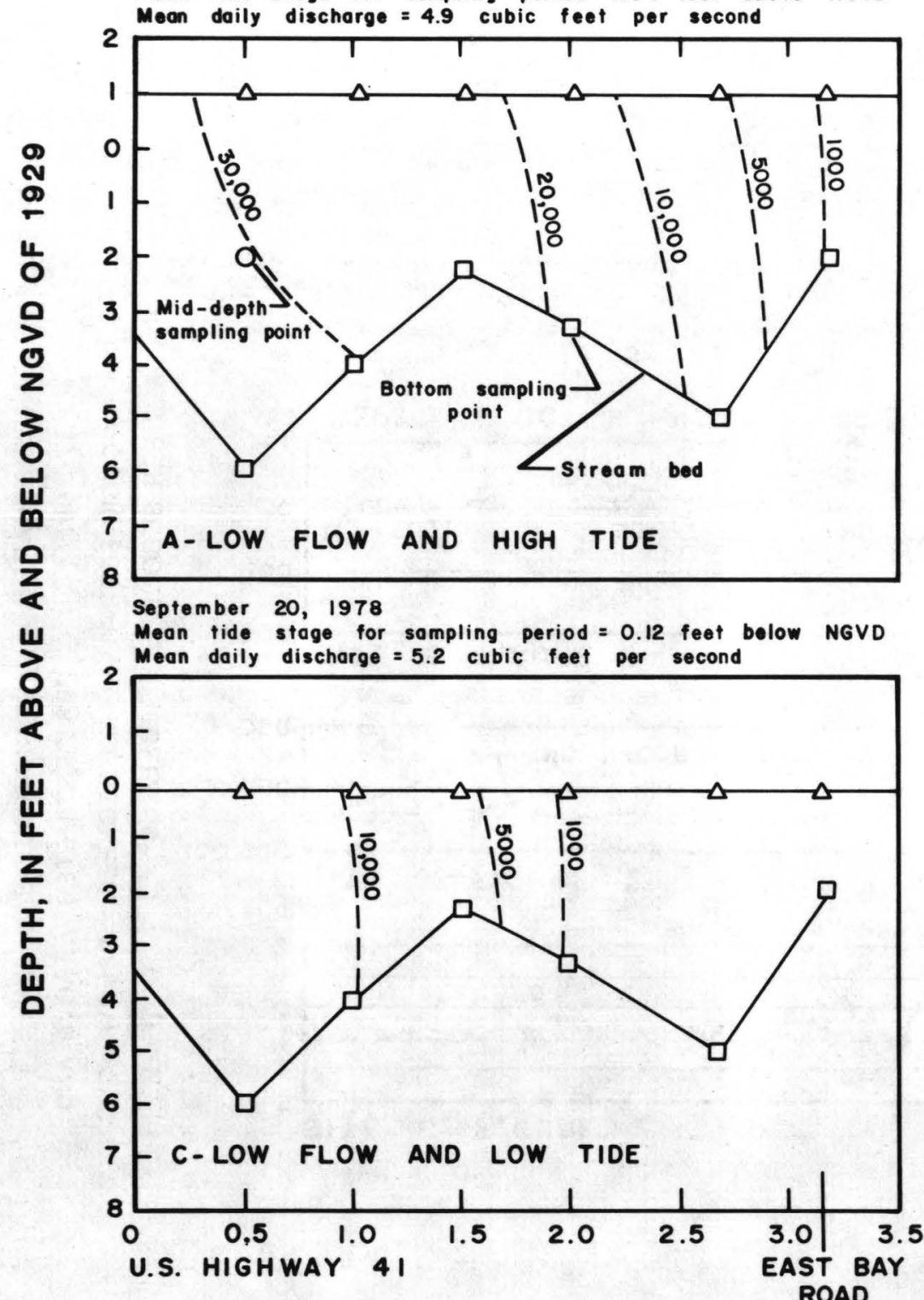

November 14, 1978

feet above NGVD Mean daily discharge $=6.4$ cubic feet per second

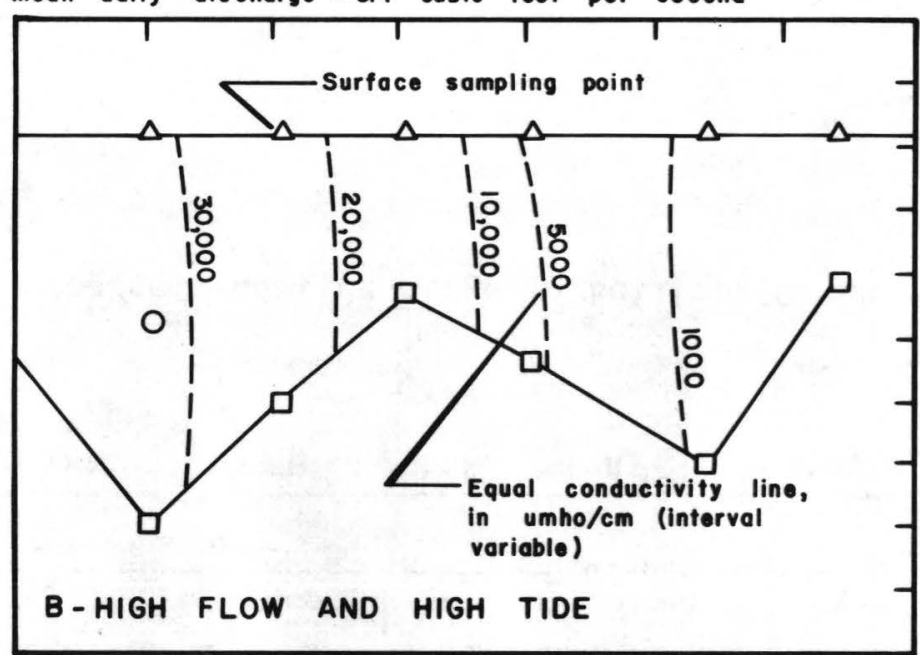

December 27,1978

Mean tide stage for sampling period $=1.22$ feet below NGVD Mean daily discharge $=24$ cubic feet per second

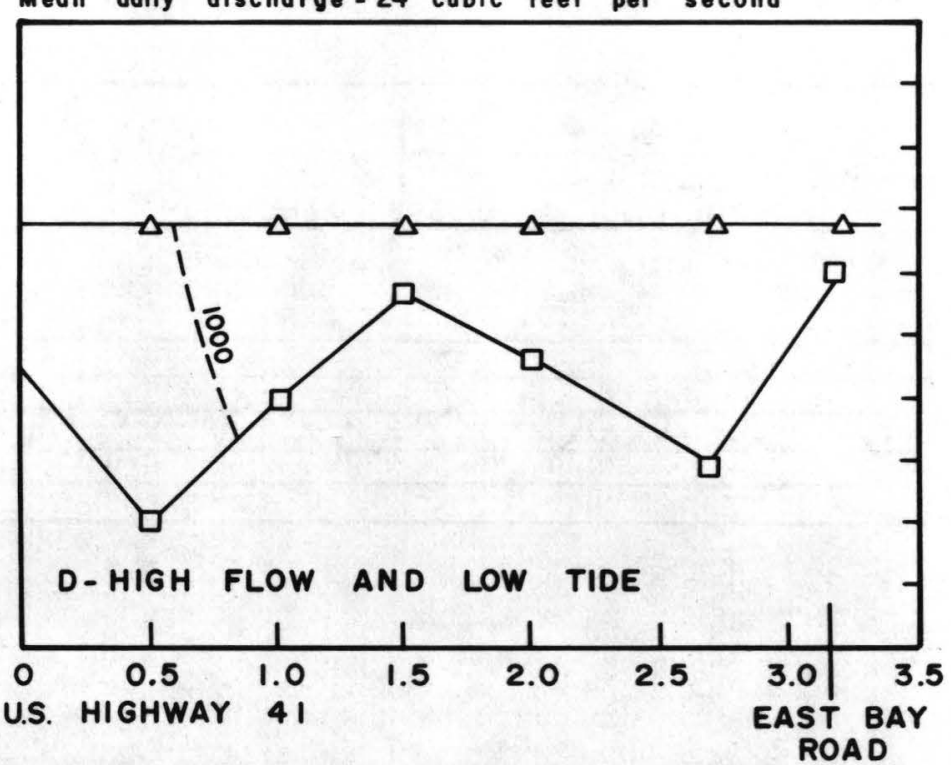

DISTANCE ABOVE U.S. HIGHWAY 41, IN MILES

Figure 11.--Conductivity profiles in Bullfrog Creek for various streamflow and tide-stage conditions. 
Relations were developed to predict the location of the saltwater interface as a function of streamflow and tide stage for the Alafia River and Bullfrog Creek. Physical characteristics and movement of the saltwater wedge are different for both streams because of differences in basin size, streamflow volume, and channel characteristics. Separate but similar analyses were used in development of equations for predicting the location of the saltwater interface in the streams.

\section{Alafia River - Predictive Equation}

The Alafia River study reach is about 11 miles in length. Tide data were collected near the lower end of the reach, and streamflow data were collected about 5 miles upstream of the reach. Because of the distance between the gages in the study reach, there is a lag between times of recorded tide and discharge; the lag being more prevalent at more distant points from the respective gages. Time lag varies, depending on the magnitude of discharge or tidal peak. Because of this, streamflow and tidestage data could not be used directly as an index for determining the location of the saltwater interface. However, conductivity, a parameter that integrates the relative effects of tide stage and streamflow, could be used as the index. The relation between location of the saltwater interface and conductivity of the Alafia River at Riverview (site 3, fig. 2 ) is shown in figure 12. As conductivity increases at the reference point, the location of the saltwater interface moves upstream. The location of the saltwater interface is a function of the conductivity at the reference point which is a function of tide stage and streamflow. The relation between conductivity at the reference point and location of the saltwater interface (vertical line with 1,000 umho/cm mean conductivity) was developed by regression analysis and is described in the following equation:

$$
\mathrm{IL}=0.021(\mathrm{CR})^{0.543}
$$

where IL $=$ Location of the 1,000 micromhos per centimeter conductivity line upstream from U.S. Highway 301, in miles;

$\mathrm{CR}=$ Conductivity at the Alafia River at Riverview (site 3, fig. 2), in micromhos per centimeter at $25^{\circ} \mathrm{C}$.

The correlation coefficient of the relation is 0.98 , and the standard error of estimate is 11.5 percent. The range of conductivity used to develop the equation was from 700 to $20,000 \mathrm{umho} / \mathrm{cm}$ at $25^{\circ} \mathrm{C}$. Applicaion of the equation for predicting the location of the saltwater interface is limited to the study reach upstream from U.S. Highway 301. Salinity along this reach was more sensitive to changes in streamflow than in other reaches. The reach above U.S. Highway 301 becomes salty when streamflow is below average and fresh when streamflow is above average and normal tide-stage conditions prevail. 


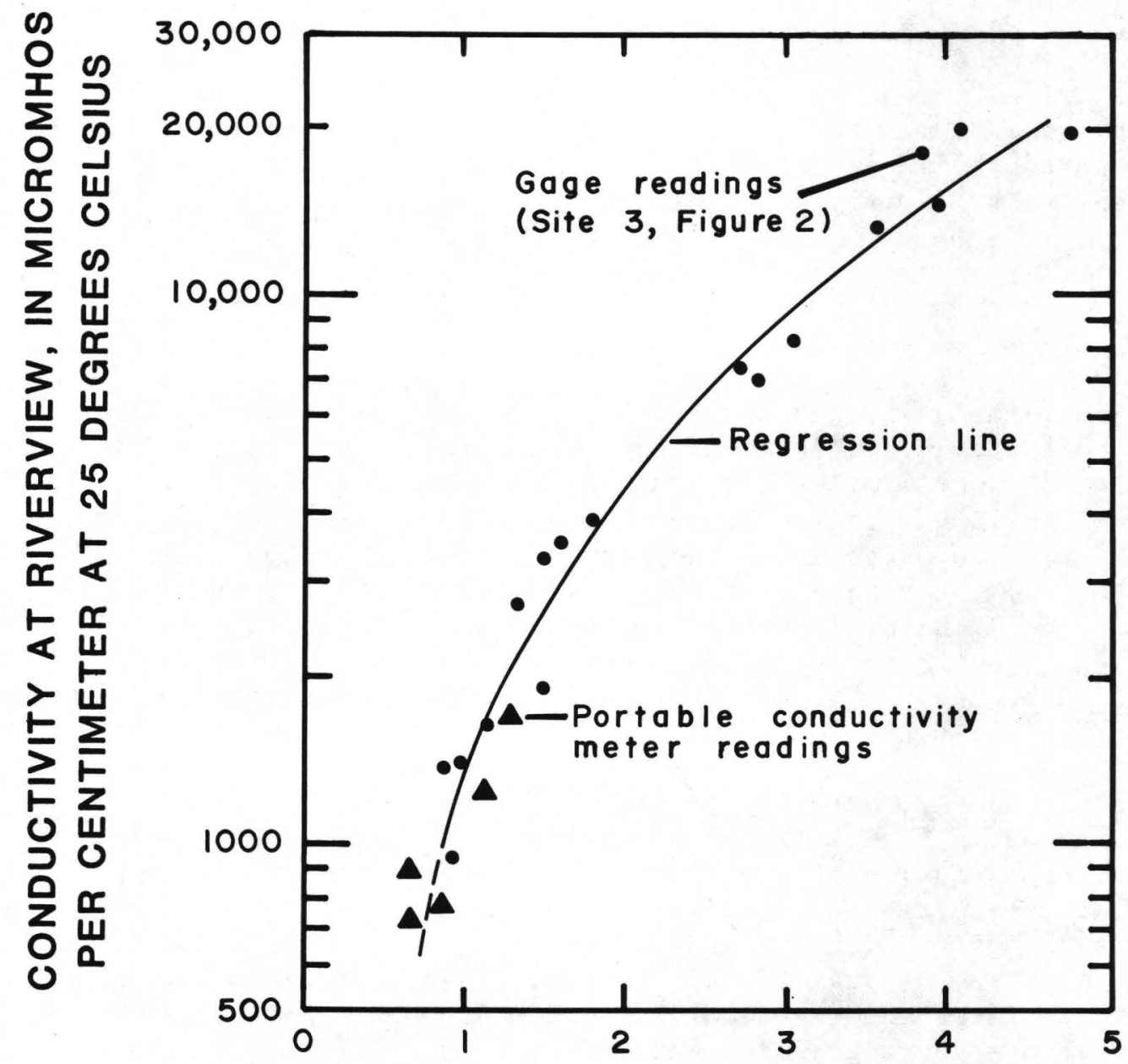

LOCATION OF SALTWATER INTERFACE ABOVE U.S. HIGHWAY 301 , IN MILES

Figure 12.--Relation between conductivity at the Alafia River at Riverview and distance of the saltwater interface upstream from U.S. Highway 301. 
Although conductivity is well suited as a reference indicator for determining the interface location, a relation was needed to relate streamflow and tide stage to the position of the interface. This relation was developed by regression analysis using daily mean conductivity, streamflow, and tide-stage data (fig. 6) and estimated locations of the saltwater interface calculated using equation 2. Because the saltwater interface moves with changes in tide and streamflow, daily mean values were used to define the mean location of the interface.

The period September 1978 to May 1979 was examined for regression analysis. During the period from January 1979 to May 1979, there were large fluctuations in streamflow that resulted in large variations in lag time and frequent flushing of the river upstream from U.S. Highway 301. The period from September 1978 to December 1978, therefore, was chosen for use in the regression. Discharge during this period ranged from 76 to 250 $\mathrm{ft}^{3} / \mathrm{s}$ and resulted in the interface remaining upstream of U.S. Highway 301 . Various lag times were tested in the regression analysis and an optimum lag time for this period of 1.5 days was selected. Daily mean tide-stages were used directly, however, a 10-foot datum adjustment was applied to tide stage to avoid negative values in the regression analysis.

The equation for estimating the daily mean location of the saltwater interface is as follows:

$$
\text { ARSIL }=\frac{1.64(\text { ARTS })^{1.46}}{(\text { ARQ })^{0.44}}
$$

where

$$
\begin{aligned}
& \text { ARSIL }= \text { Daily mean location of the saltwater Interface } \\
& \text { upstream from U.S. Highway 41, in miles; } \\
& \text { ARTS = Daily mean tide stage plus } 10 \text { feet at U.S. Highway } \\
& \quad 41 \text { (site 2, fig. 2), in feet above NGVD of 1929; } \\
& \text { ARQ = Daily mean discharge of the Alafia River at Lithia } \\
& \quad \text { (site 5, fig. 2) lagged } 1.5 \text { days, in cubic feet } \\
& \text { per second. }
\end{aligned}
$$

The multiple correlation coefficient for this equation is 0.95 , and the standard error of the estimate is 4.8 percent. This indicates that about two-thirds of the interface locations used in this regression lie within 4.8 percent of the predicted value. Predicted locations calculated using equation 3, and locations determined using daily mean conductivities for site 3, figure 2, and equation 2 are shown in figure 13 . The range of input data and limitations of equation 3 are as follows:

\begin{tabular}{l|c|c}
\hline \multicolumn{1}{c|}{ Parameter } & Mimimum value & Maximum value \\
\hline $\begin{array}{c}\text { Discharge (site 5, fig. 2), in cubic feet } \\
\text { per second }\end{array}$ & 76 & 250 \\
$\begin{array}{l}\text { Tide stage (site 3, fig. 2), in feet above } \\
\text { NGVD of 1929 }\end{array}$ & -0.40 & 1.50 \\
$\begin{array}{l}\text { Location of saltwater interface upstream } \\
\text { from U.S. Highway 41, in miles }\end{array}$ & 4.6 & 8.7 \\
\hline
\end{tabular}




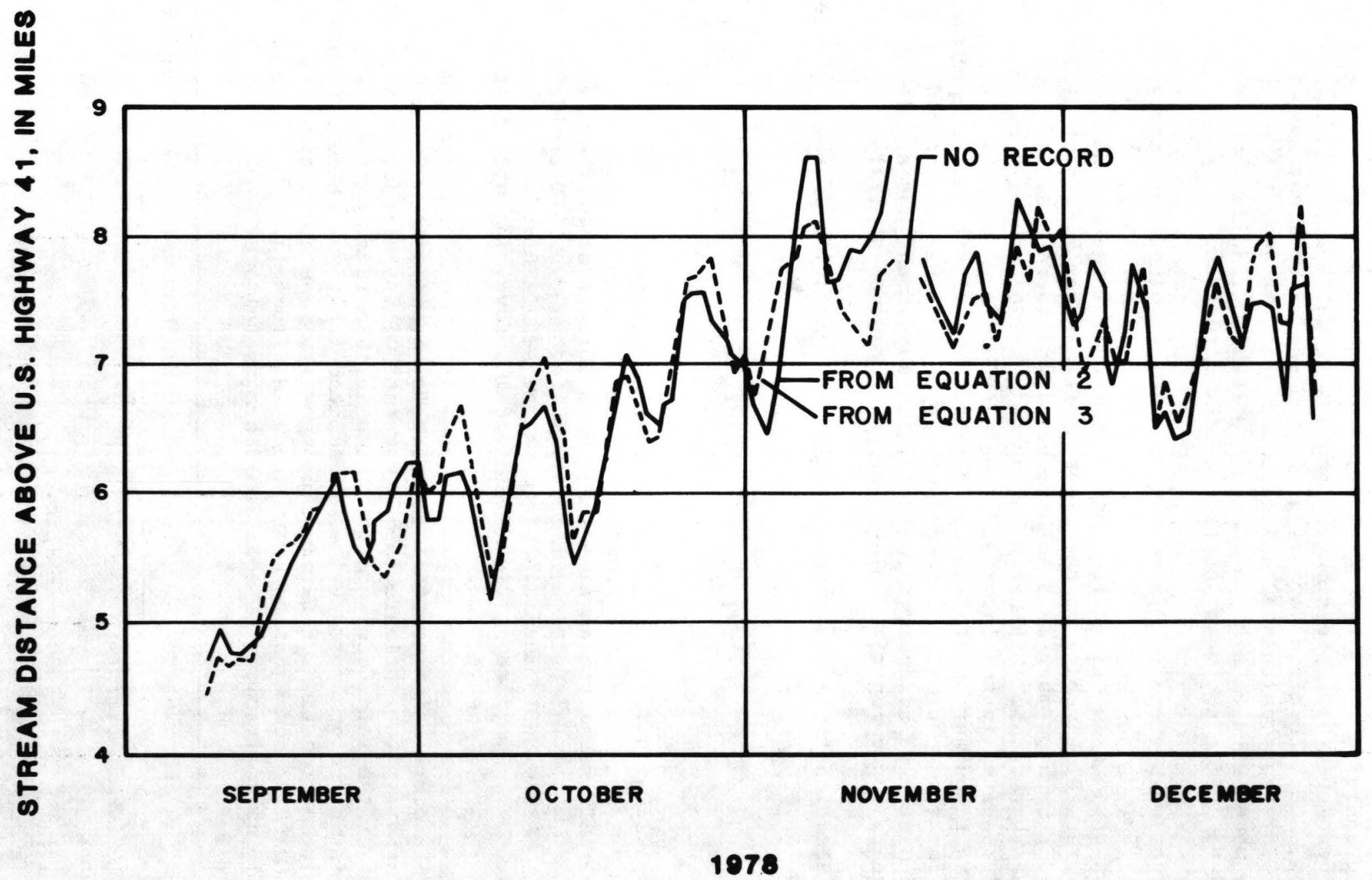

Figure 13.--Comparison of daily mean locations of the saltwater interface in the Alafia River. 
Results of the regression analysis indicate that discharge is more significant than tide stage in predicting the interface location. A 10 percent increase in discharge resulted in a 4 percent reduction in the distance of the interface upstream from U.S. Highway 41, whereas a 10 percent increase in tide stage resulted in an upstream movement of the saltwater interface of 1.3 percent.

Maximum upstream movement of saltwater will occur when there is high tide and no streamflow. For zero discharge and negligible amplification of a tidal wave, the saltwater interface will be located at a point where tide-stage elevation is equal to streambed elevation. The estimated location of the saltwater interface for minimum, average, and maximum daily mean tide-stage elevations and zero streamflow is shown in figure 14.

Locations of the saltwater interface ${ }_{3}$ cannot be determined using equation 3 for discharges less than $76 \mathrm{ft}^{3} / \mathrm{s}$. Estimates of the location of the saltwater interface when discharge is less than $76 \mathrm{ft} / \mathrm{s}$ may be made by linear extrapolation between interface locations shown in figure 14 for zero discharge and the lower limits of equation 3 . Figure 15 shows the estimated location of the saltwater interface using equation 3

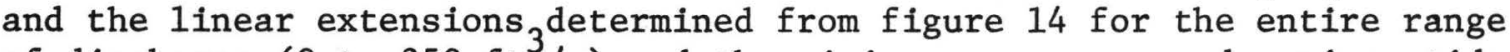
of discharge ( 0 to $250 \mathrm{ft} / \mathrm{s}$ ) and the minimum, average, and maximum tidetage values.

\section{Application of Equation}

Low-flow characteristics of streams often determine their suitability as a source of water. Reduction of discharge during a low-flow period is of critical importance in this study. The magnitude and frequency of annual low flows for selected periods for the Alafia River at Lithia (site 5, fig. 2) are in figure 16. To illustrate the effects of withdrawals on the location of the saltwater interface during low-flow periods, low-flow frequency data for the 2-year recurrence interval and mean tide-stage conditions $(0.64$ feet above NGVD of 1929) were used with equation 3 to estimate mean daily locations of the saltwater interface (fig. 17) for the selected periods. Mean daily locations of the saltwater interface shown in figure 17 for percentage reductions in 2-year low flows from 0 to 100 percent illustrate the effect of withdrawals from the Alafia River without storage. Storage may be defined as any type of impoundment that will retain streamflow for future use. The estimated mean daily location of the saltwater interface for the 120- to 7-day, 2-year low flow without withdrawals ranged from 5.9 to 9.0 miles upstream from U.S. Highway 41. However, if 50 percent of the 120-day, 2-year low flow was diverted for water supply (withdrawal of $70 \mathrm{ft}^{3} / \mathrm{s}$ ), an upstream movement of the mean daily location of the saltwater interface of approximately 2.0 miles would be induced. If 50 percent of the 7-day, 2year low flow was diverted (withdrawal of $20 \mathrm{ft} / \mathrm{s}$ ), an upstream movement of approximately 0.8 mile would result. This information is useful in determining portions of the study reach that will be affected by saltwater for natural and reduced streamflow conditions without storage. 


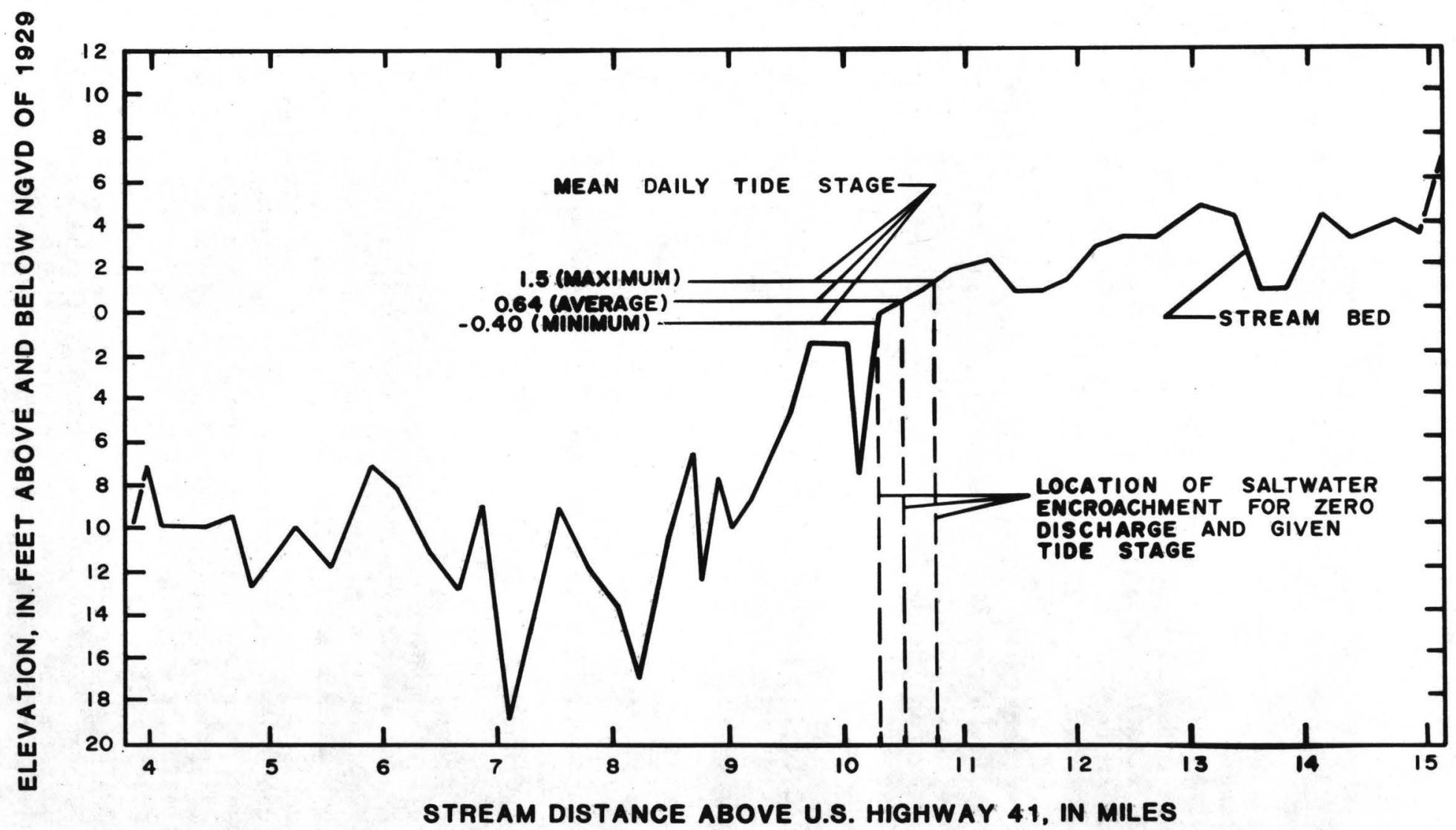

Figure 14.--Streambed elevations and location of the saltwater interface for zero discharge and selected tide-stage conditions in the Alafia River. 


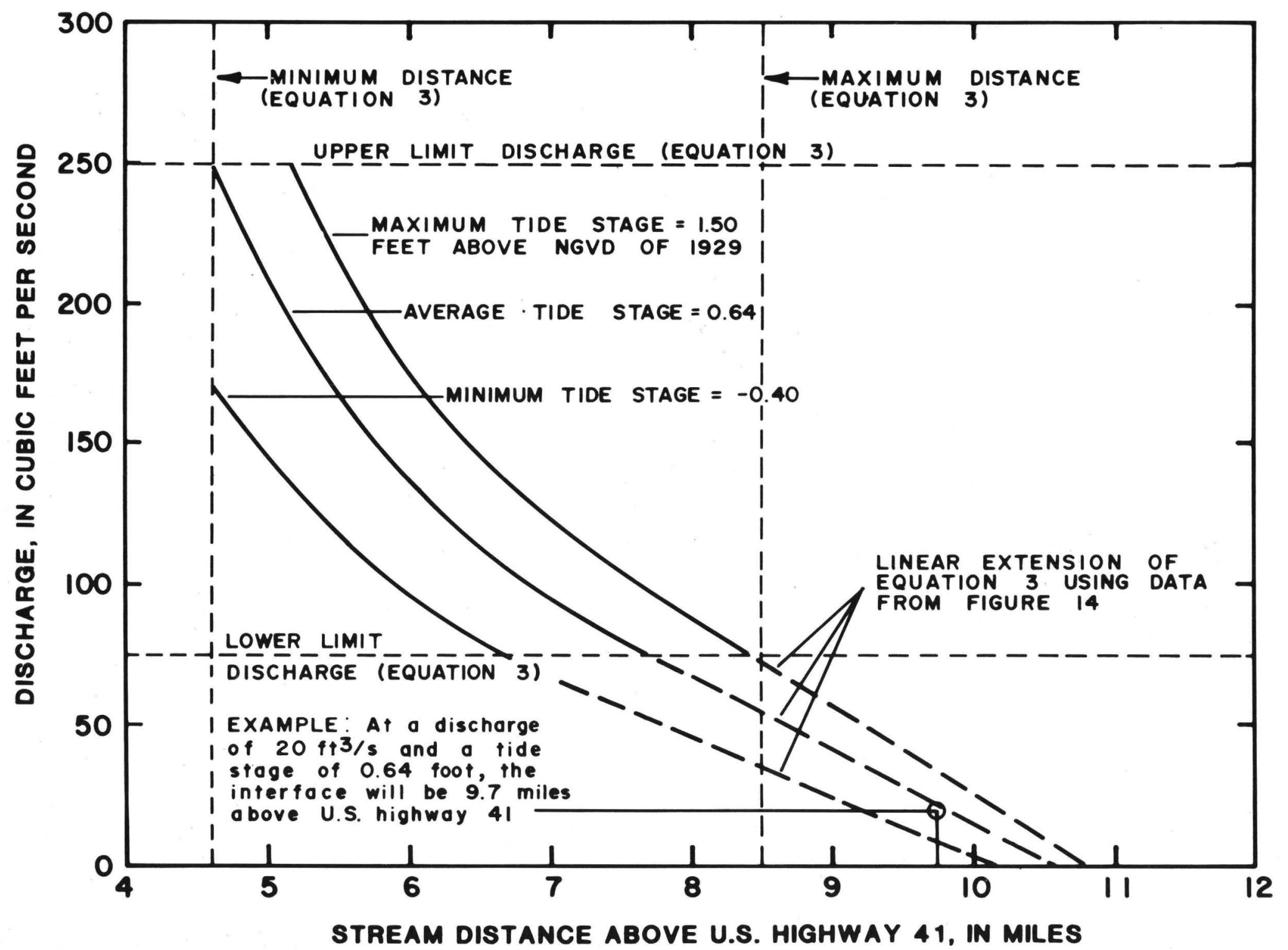

Figure 15.--Location of the saltwater interface in the Alafia River as a function of discharge for selected tide-stage conditions. 


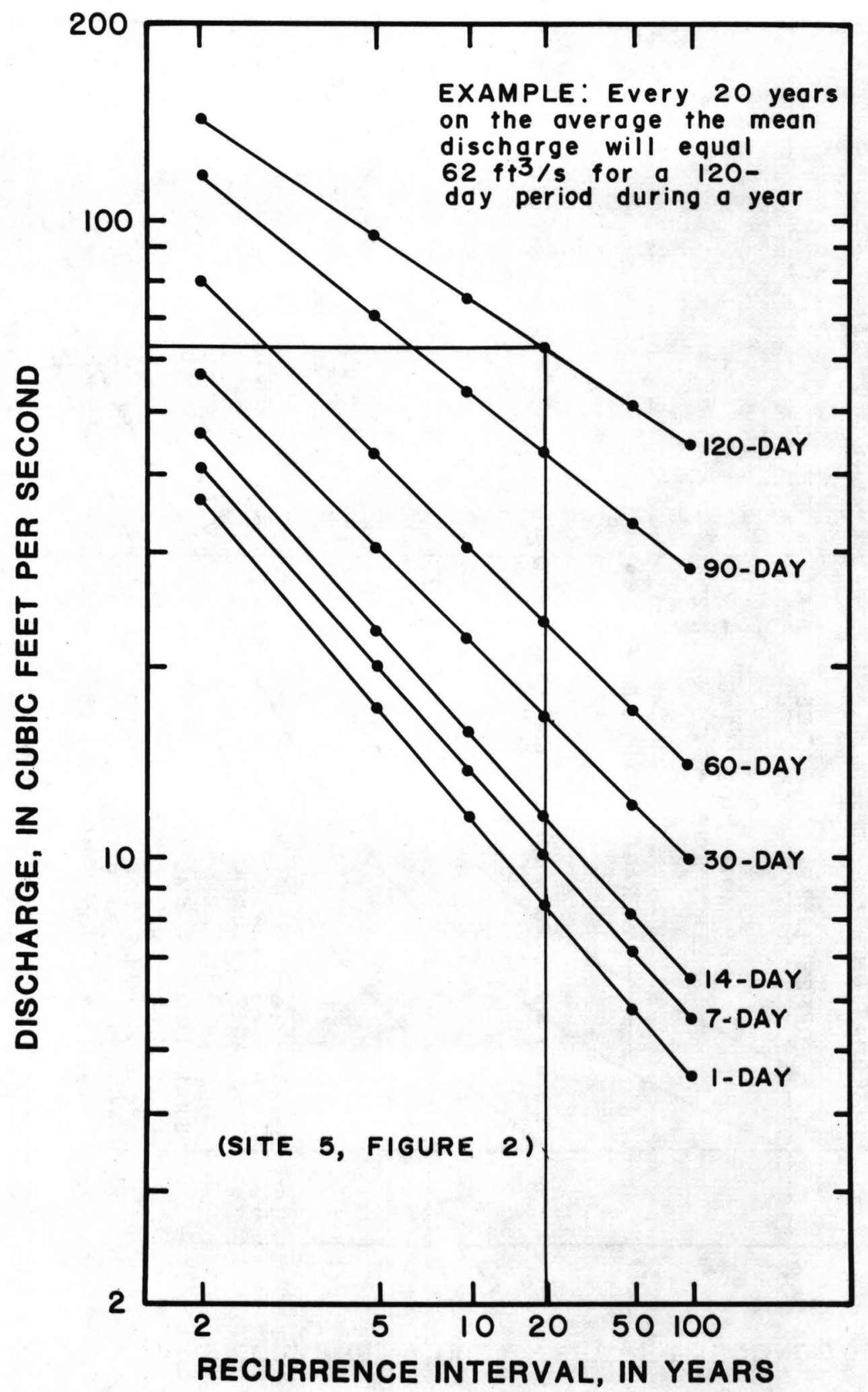

Figure 16.--Magnitude and frequency of annual low flow of the Alafia River at Lithia. 


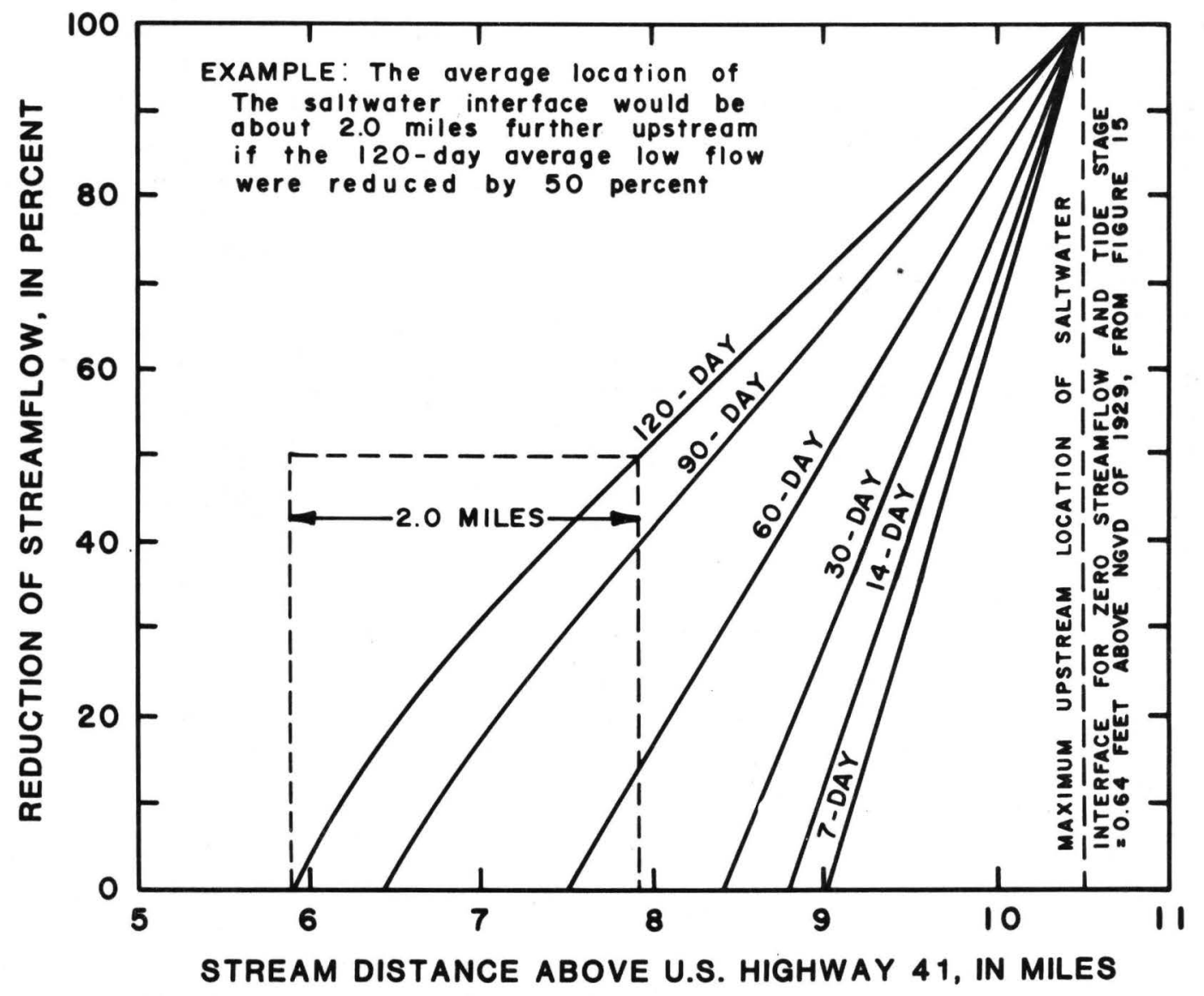

Figure 17.--Effect of withdrawals from the 2-year low flows on the location of the saltwater interface in the Alafia River. 
Due to the low-flow characteristics of the Alafia River and minimum streamflow requirements imposed by the Southwest Florida Water Management District, continuous withdrawals of large amounts of water from the river would be difficult without storage. To examine the effects of withdrawals on the mean daily location of the saltwater interface, a storage analysis was done for the Alafia River. Low-flow discharges having 20-year recurrence intervals (fig. 16) were used to determine the storage required to sustain various rates of water-supply withdrawal or draft rates (fig. 18). Figure 18 shows that about 2,0030 Mgal of storage would be required to support a draft of about $66 \mathrm{ft}^{3} / \mathrm{s}$ or $43 \mathrm{Mgal} / \mathrm{d}$. The draft of $43 \mathrm{Mgal} / \mathrm{d}$ would not include reservoir losses such as evaporation, seepage, and loss of storage due to siltation or releases to meet minimum flow requirements. Because of regulatory requirements of the Southwest Florida Water Management District regarding minimum streamflow rates, withdrawals of $43 \mathrm{Mgal} / \mathrm{d}$ could not be supported during a 20-year drought with a storage of 2,000 Mgal. When inflow is less than the regulatory minimum flow, outflow cannot be reduced to less than the natural flow (equal to the inflow), and withdrawals must be taken from storage. An example of flow deficiency for a hypothetical drought period is given below.

Assume a reservoir with a capacity of 2,000 Mgal of storage is deve1oped for the Alafia River and that the reservoir is full at the beginning of April. Avȩrage inflow to the reservoir using the 20-year, 90-day drought flow is $43 \mathrm{ft}^{3} / \mathrm{s}$ (from fig. 16) or $27.8 \mathrm{Mgal} / \mathrm{d}$. This average inflow may be prorated to obtain monthly average inflows of $13.7,27.8$, and $41.9 \mathrm{Mgal} / \mathrm{d}$ for April, May, and June, respectively. Reservoir releases were determined to be minimum rates of flow as established using criteria of the Southwest Florida Water Management District (SWFWMD, 1974). Rates of flow are determined for each month using the average of the five lowest monthly mean discharges for the preceding 20 years. Minimum rates of flow are defined as 70 percent of these values for the 4 wettest months and 90 percent of these values for the remaining 8 months. Minimum flow rates for the Alafia River at Lithia (site 5, fig. 2) are 44, 47.5, and $62.2 \mathrm{Mgal} / \mathrm{d}$ for April, May, and June, respectively. Evaluating present uses of the Alafia River and possible future development of the river, a withdrawal of $24 \mathrm{Mgal} / \mathrm{d}$ was considered for this example. The following table illustrates the deficiency in storage.

\begin{tabular}{|c|c|c|c|c|c|c|c|}
\hline \multirow{2}{*}{ Month } & \multirow{2}{*}{$\begin{array}{l}\text { Beginning } \\
\text { storage } \\
\text { (Mga1) }\end{array}$} & \multicolumn{3}{|c|}{$\begin{array}{c}\text { Average monthly } \\
\text { inflow and outflow } \\
(\mathrm{Mgal} / \mathrm{d})\end{array}$} & \multicolumn{2}{|c|}{$\begin{array}{c}\text { Allowable } \\
\text { monthly } \\
\text { withdrawal } \\
\text { (Mgal) }\end{array}$} & \multirow{2}{*}{$\begin{array}{l}\text { Average } \\
\text { draft } \\
\text { (Mgal/d) }\end{array}$} \\
\hline & & Inflow & $\begin{array}{l}\text { Minimum } \\
\text { flow } \\
\text { requirement }\end{array}$ & $\begin{array}{l}\text { Required } \\
\text { outflow }\end{array}$ & $\begin{array}{l}\text { From } \\
\text { inflow }\end{array}$ & $\begin{array}{l}\text { From } \\
\text { storage }\end{array}$ & \\
\hline April & 2,000 & 13.7 & 44.0 & 13.7 & 0 & 720 & 24 \\
\hline May & 1,280 & 27.8 & 47.5 & 27.8 & 0 & 744 & 24 \\
\hline June & 536 & 41.9 & 62.2 & 41.9 & 0 & 536 & 17.9 \\
\hline July & 0 & & & & & & \\
\hline
\end{tabular}




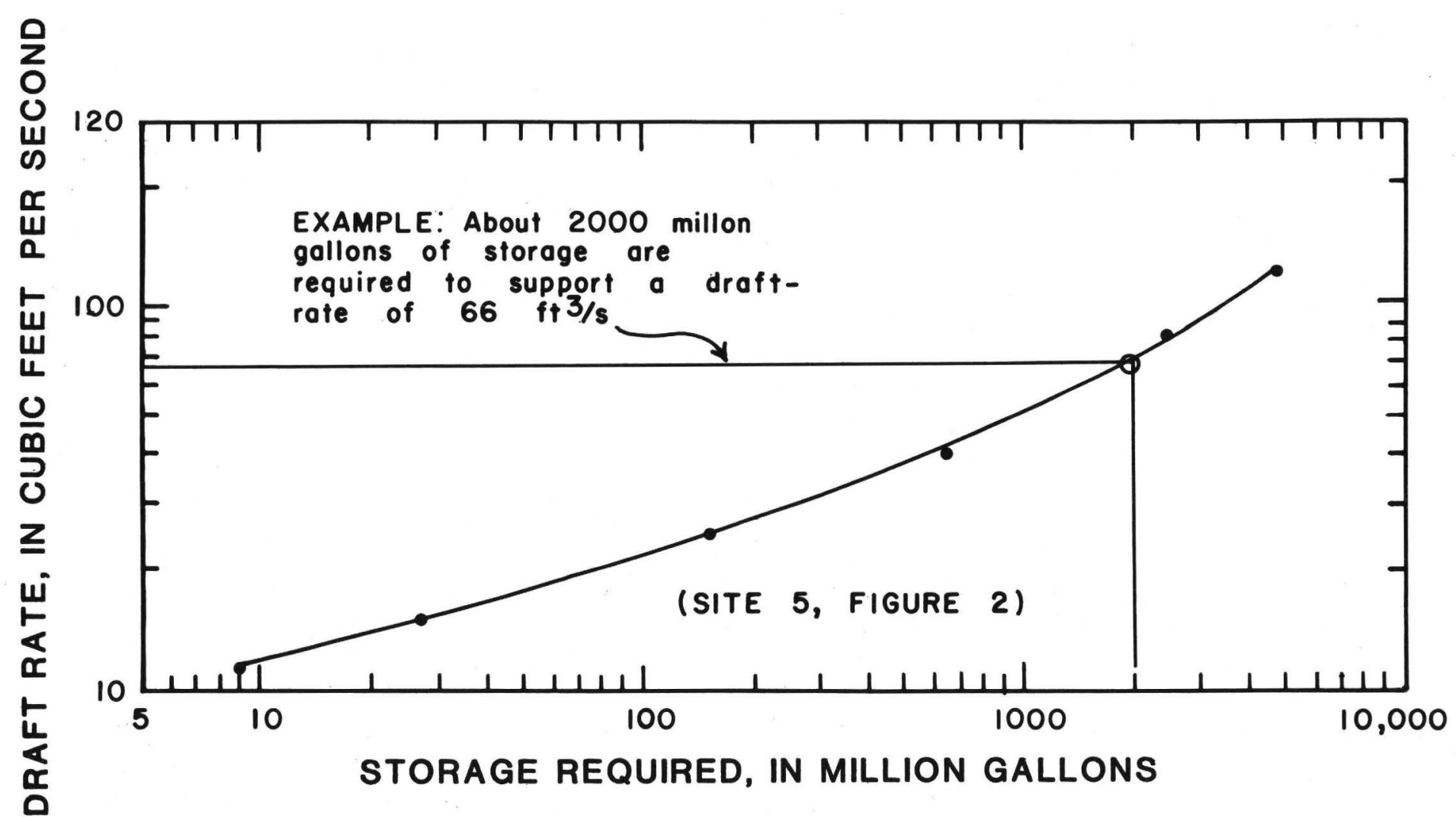

Figure 18.--Draft-storage relation for 20-year low flows at the Alafia River at Lithia. 
The April draft of $24.0 \mathrm{Mgal} / \mathrm{d}$ is from storage because the minimum flow requirement of $44 \mathrm{Mgal} / \mathrm{d}$ exceeds inflow. Beginning storage for May, adjusted for the April withdrawa1, is 1,280 Mgal. Because inflow for May is less than the required minimum rate of $47.5 \mathrm{Mgal} / \mathrm{d}$, withdrawals must again be taken from storage, resulting in available storage of $536 \mathrm{Mgal}$ for June. Because inflow for June is less than the minimum flow requirement of 62.2 , withdrawals again must be supported by storage. The remaining storage of $536 \mathrm{Mgal}$ for June will only support a draft of $17.9 \mathrm{Mgal} / \mathrm{d}$ for the month. For these release regulations, a withdrawal rate of $24 \mathrm{Mgal} / \mathrm{d}$ could not be maintained. However, if only 50 percent of the minimum flow rates were required, the draft of about $24 \mathrm{Mgal} / \mathrm{d}$ would be possible, as outlined in the following table.

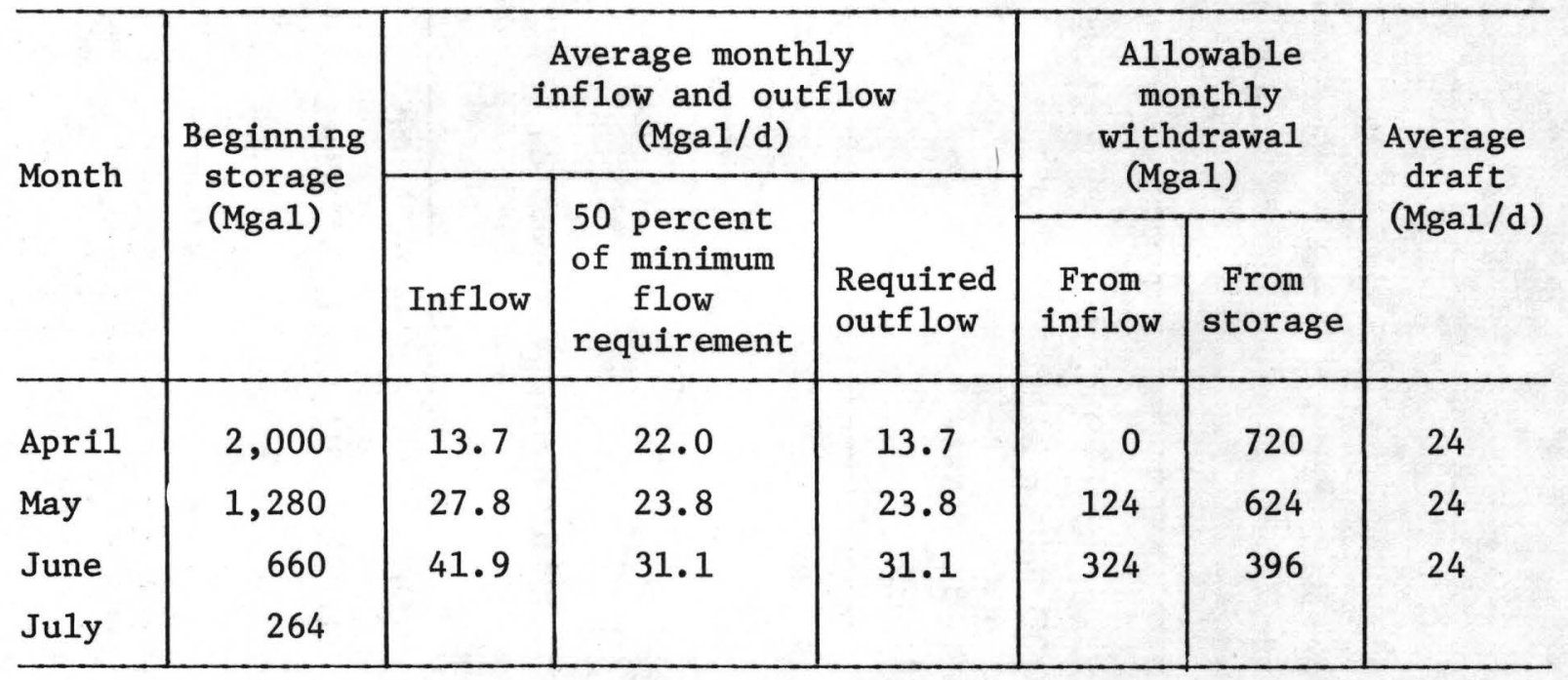

On April 1, a storage of $2,000 \mathrm{Mgal}$ is available. Inflow of 13.7 $\mathrm{Mgal} / \mathrm{d}$ during April is less than the minimum flow rate of $22 \mathrm{Mgal} / \mathrm{d}$; therefore, the $24 \mathrm{Mgal} / \mathrm{d}$ withdrawal must come from storage. Beginning in May when available storage is $1,280 \mathrm{Mgal}$, a draft of $24 \mathrm{Mgal} / \mathrm{d}$ would be possible with $4.0 \mathrm{Mgal} / \mathrm{d}$ from excess inflow and $20.0 \mathrm{Mgal} / \mathrm{d}$ from storage. By June, storage is depleted to $660 \mathrm{Mgal}$; however, the draft of $24 \mathrm{Mgal} / \mathrm{d}$ is possible, $10.8 \mathrm{Mgal} / \mathrm{d}$ from excess inflow and $13.2 \mathrm{Mgal} / \mathrm{d}$ from storage.

As illustrated by this example, a reduction in minimum flow rates by about 50 percent would allow a sustained withdrawal of about $24 \mathrm{Mgal} / \mathrm{d}$ for April, May, and June. A comparison of reservoir outflows with full compliance and a 50 percent reduction in minimum flow rates illustrates the extent of saltwater encroachment caused by the reduction in minimum streamflow requirements. 


\begin{tabular}{|c|c|c|c|c|c|c|c|}
\hline \multicolumn{4}{|c|}{ FULL COMPLIANCE } & \multicolumn{4}{|c|}{50 PERCENT COMPLIANCE } \\
\hline Month & $\begin{array}{l}100 \text { percent } \\
\text { minimum } \\
\text { flow } \\
\text { require- } \\
\text { ment } \\
(\mathrm{Mgal} / \mathrm{d})\end{array}$ & $\begin{array}{l}\text { Outflow } \\
\text { rate } \\
(\mathrm{Mgal} / \mathrm{d})\end{array}$ & $\begin{array}{c}\text { Distance } \\
\text { of } \\
\text { saltfront } \\
\text { upstream } \\
\text { from } \\
\text { U.S. } \\
\text { Highway } \\
41 \\
\text { (mi) }\end{array}$ & $\begin{array}{l}50 \\
\text { percent } \\
\text { of } \\
\text { minimum } \\
\text { flow } \\
\text { require- } \\
\text { ment } \\
\text { (Mgal/d) }\end{array}$ & $\begin{array}{l}\text { Outflow } \\
\text { rate } \\
\text { (Mgal/d) }\end{array}$ & $\begin{array}{c}\text { Distance } \\
\text { of } \\
\text { saltfront } \\
\text { upstream } \\
\text { from } \\
\text { U.S. } \\
\text { Highway } \\
41 \\
\text { (mi) }\end{array}$ & $\begin{array}{l}\text { Extent of } \\
\text { induced } \\
\text { saltwater } \\
\text { intrusion } \\
\text { (mi) }\end{array}$ \\
\hline April & 44.0 & 13.7 & 10.0 & 22.0 & 13.7 & 10.0 & 0.0 \\
\hline May & 47.5 & 27.8 & 9.5 & 23.8 & 23.8 & 9.8 & 0.3 \\
\hline June & 62.2 & 41.9 & 8.9 & 31.1 & 31.1 & 9.3 & 0.4 \\
\hline
\end{tabular}

To meet draft requirements of $24 \mathrm{Mgal} / \mathrm{d}$ through a 20-year drought would require relaxation of minimum flow requirements by approximately 50 percent. This relaxing of minimum flow rates by 50 percent to accommodate water supply demands would induce upstream movement of the mean daily 1ocation of the saltwater interface by about 0.3 mile in May and 0.4 mile in June.

To determine the percentage of time various portions of the Alafia River would be affected by saltwater conditions, tide and flow duration curves were developed and used to estimate interface locations. The flow duration curve shown in figure 19 for the Alafia River at Lithia (site 5, fig. 2) indicates the percentage of time that daily discharges were equaled or exceeded during the period of record from 1933 to 1978. Duration curves were also developed for daily mean tide stage and instantaneous tide stage (15-minute intervals) based on Hillsborough Bay (site 2, fig. 2) records for the period from September 1, 1978, to May 31, 1979 (fig. 20).

Daily mean locations of the saltwater interface, computed using streamflows of known duration and a constant tide stage of 0.64 feet above NGVD of 1929 are listed below and shown on a map of the study reach in figure 21. 


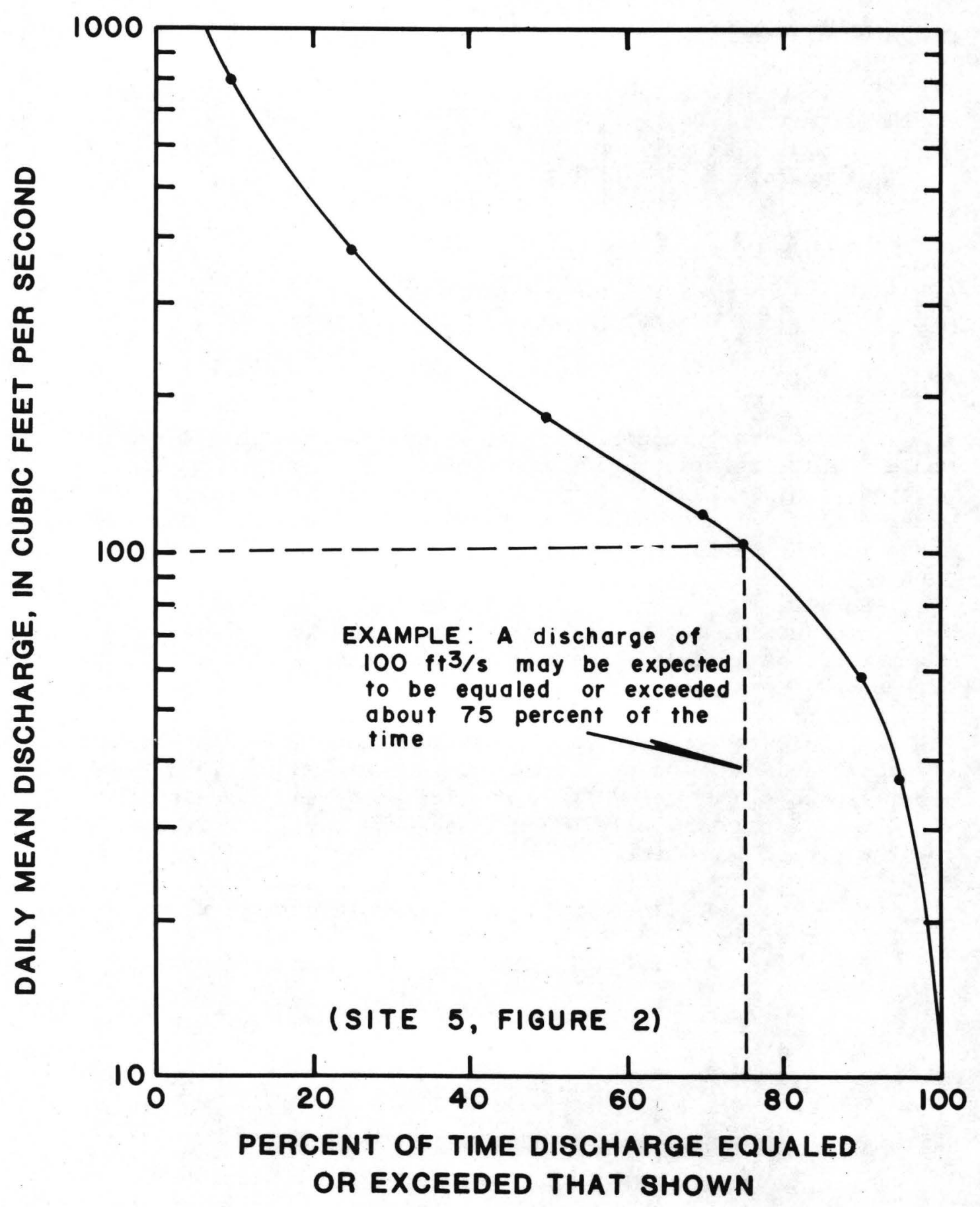

Figure 19.--Flow-duration curve for the Alafia River at Lithia for 1933-78. 


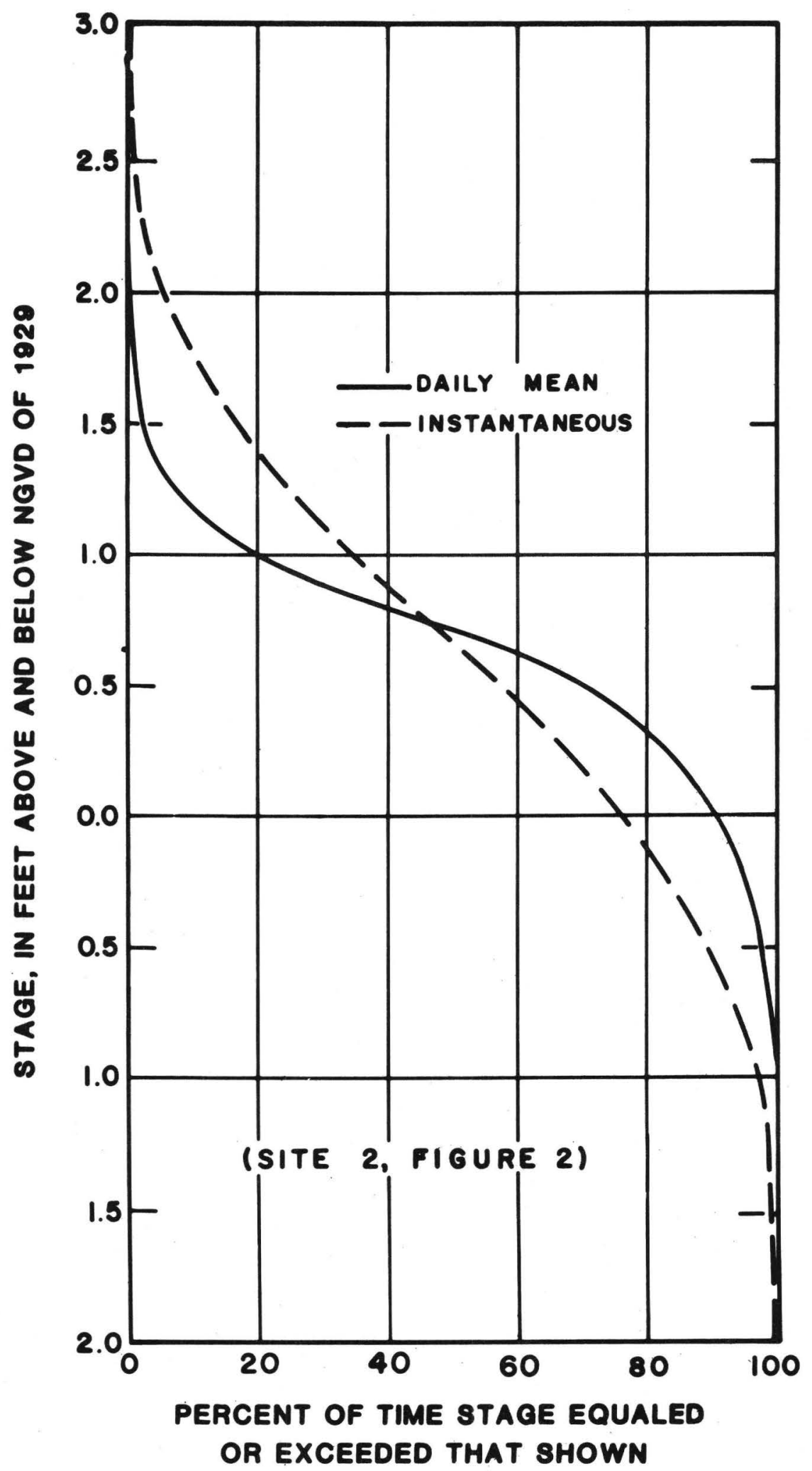

Figure 20.--Tide-stage duration curves for Hillsborough Bay at the mouth of the Alafia River for September 1, 1978, to May 31, 1979. 


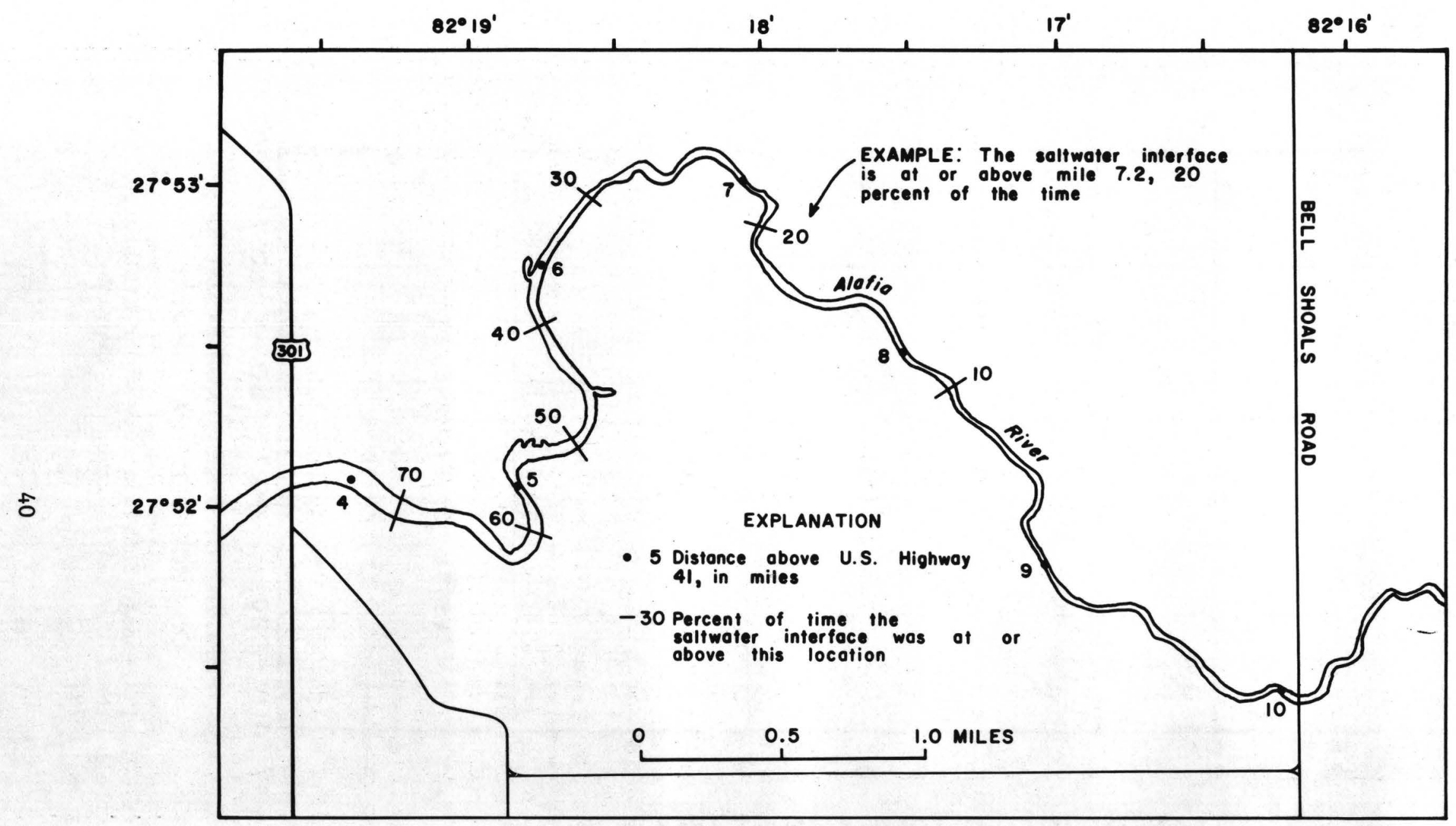

Figure 21.--Location and duration of the saltwater interface in the Alafia River for constant tide stage and variable streamflow. 


\begin{tabular}{c|c}
\hline Percent of time & $\begin{array}{c}\text { Distance saltwater interface is } \\
\text { upstream from U.S. Highway 41, } \\
\text { in miles }\end{array}$ \\
\hline 10 & 8.2 \\
30 & 7.2 \\
40 & 6.3 \\
50 & 5.8 \\
60 & 5.3 \\
70 & 4.8 \\
\hline
\end{tabular}

This type of information may be used in a biological evaluation to determine areas of the stream that will be affected by saltwater for different periods of time.

\section{Bullfrog Creek - Predictive Equation}

There are several areas in Bullfrog Creek where movement of the saltwater wedge reacts differently to fluctuations in streamflow and tide stage; therefore, study of this stream required different analysis than that used for the Alafia River. As shown in figure 11, a deep channel occurs just upstream from U.S. Highway 41. Subsequent1y, the depth decreases and is relatively shallow near the center of the study reach, after which the depth again increases to a point approximately 2.7 miles upstream from U.S. Highway 41. A bottom configuration of this type produces nonuniform cross-sectional areas, and variations in streamflow and tide stage result in nonuniform movement of the saltwater interface. Movement of the saltwater interface from the mouth to approximately 1.0 mile upstream from U.S. Highway 41 is small for relatively large fluctuations in streamflow. As streamflow and tide conditions change and the interface moves from 1.0 to 2.5 miles upstream from U.S. Highway 41, small changes in streamflow cause relatively large changes in interface location. Sufficient data are not available to evaluate movement of the interface in reaches greater than 2.5 miles upstream from U.S. Highway 41.

Predictive equations describing the location of the saltwater interface were developed in a regression analysis using instantaneous interface locations and tide-stage and daily mean discharge data. Analyses were made for streamflow conditions as follows:

for Discharge between 12.3 and $14.9 \mathrm{ft}^{3} / \mathrm{s}$

$$
\text { BCIL }=0.57(\mathrm{TS})-0.29(\mathrm{Q})-0.04
$$


for Discharge between 15 and $71 \mathrm{ft}^{3} / \mathrm{s}$

$$
\mathrm{BCIL}=0.53(\mathrm{TS})-0.03(\mathrm{Q})-3.69
$$

where $\quad$ BCIL $=$ Distance of the saltwater interface upstream from U.S. Highway 41, in miles;

TS = Tide stage at U.S. Highway 41 (site 6, fig. 2),

in feet above NGVD of 1929 plus 10 feet;

$Q=$ Daily mean discharge for Bullfrog Creek near Wimauma (site 8, fig. 2), in cubic feet per second.

The multiple correlation coefficient for equation 4 is 0.98 and the standard error at the mean is 5.7 percent. Equation 5 has a multiple correlation coefficient of 0.99 and a standard error at the mean of 5.3 percent. The range of input values and limitations of the equations are as follows:

\begin{tabular}{l|r|r}
\hline \multicolumn{1}{c|}{ Parameter } & \multicolumn{2}{c}{ Range of input data } \\
\cline { 2 - 3 } & Equation 4 & Equation 5 \\
\hline Streamflow, in cubic feet per second & 12.3 to 14.9 & 15 to 71 \\
$\begin{array}{l}\text { Tide stage, in feet above NGVD of } 1929 \\
\begin{array}{l}\text { Saltwater interface location upstream from } \\
\text { U.S. Highway 41, in miles }\end{array}\end{array}$ & $\begin{array}{l}0.0 \text { to } 1.8 \\
-1.1 \text { to } 1.8\end{array}$ \\
\hline
\end{tabular}

Regression lines of tide stage versus location of the saltwater interface for various streamflows were determined using equations 4 and 5 and are shown in figure 22.

For equation 4 , a 10 percent increase in streamflow results in a 13.5 percent reduction in the distance of the saltwater interface located upstream from U.S. Highway 41. A 10 percent increase in tide stage produced an upstream movement of the interface of 1.9 percent. For equation 5, a 10 percent increase in streamflow causes a 3.7 percent reduction in the distance of the saltwater interface location, whereas a 10 percent increase in tide stage resulted in a 0.7 percent increase in the distance of the interface location. In both equations, streamflow was determined to be more significant than tide. In addition, equation 4 is more sensitive to fluctuations in streamflow than equation 5 .

\section{Application of Equation}

Sufficient channel geometry data were not available for Bullfrog Creek to estimate the extent of saltwater encroachment for zero discharge. Without this information, the range of predictive equations could not be extended as had been done for the Alafia River. 


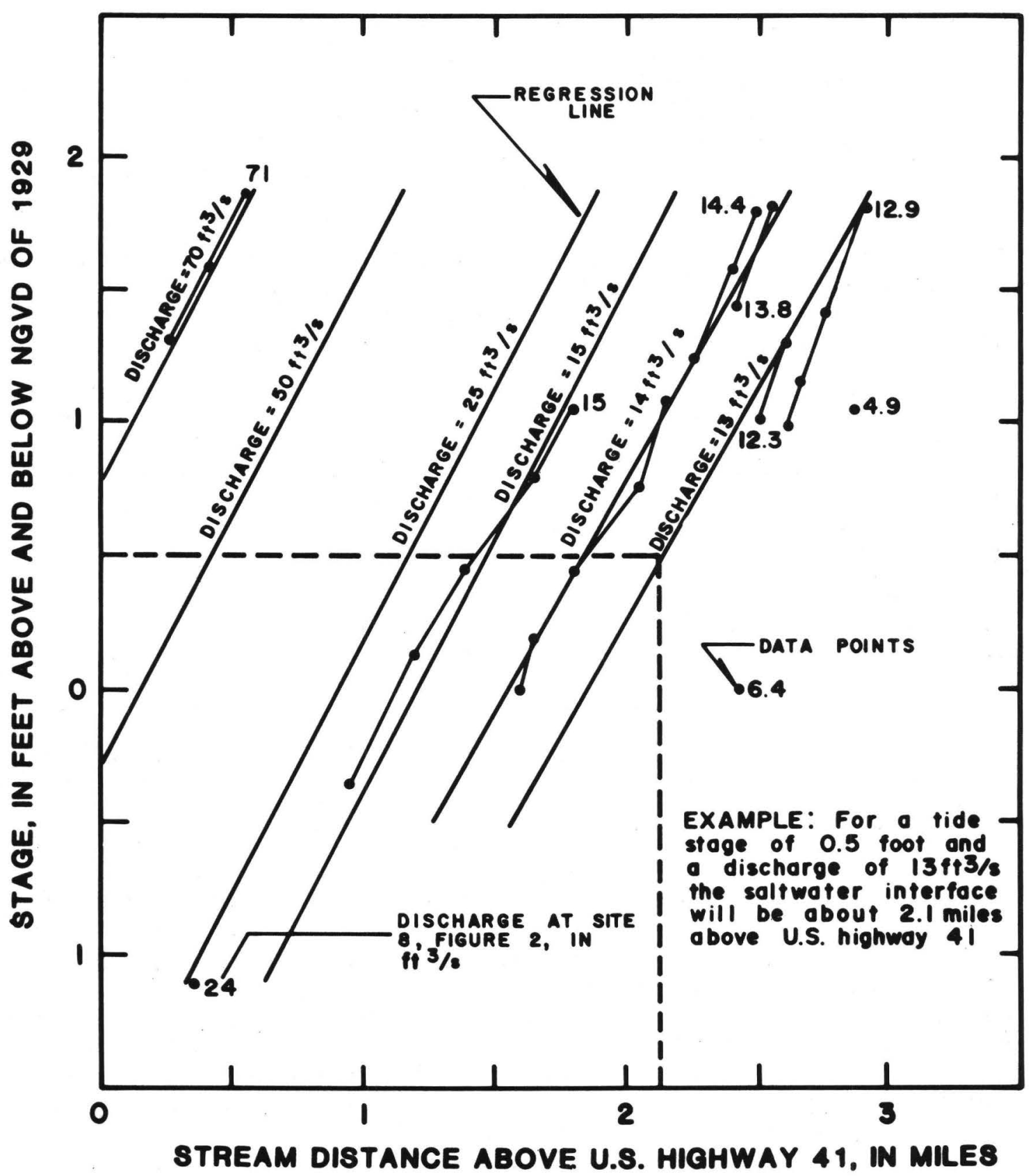

Figure 22.--Relation between location of the saltwater interface, discharge, and tide stage in Bullfrog Creek. 
Application of the predictive equations to Bullfrog Creek consists of a duration analysis to determine the percent of time the mean daily location of the saltwater interface would be at various points in the creek. Although not used in this application, a flow duration curve for Bullfrog Creek for the period from October 1956 to October 1958 and May 1977 to September 1979

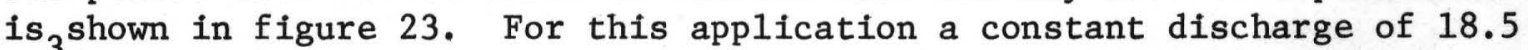
$\mathrm{ft}^{3} / \mathrm{s}$, (50 percent of the average daily flow) was used with mean daily tide stage duration data from figure 20. Computed mean daily locations of the saltwater interface and duration percentages are listed below and shown in figure 24 .

\begin{tabular}{c|c}
\hline Percent of time & $\begin{array}{c}\text { Distance of saltwater interface } \\
\text { upstream from U.S. Highway 41, } \\
\text { in miles }\end{array}$ \\
\hline 10 & 1.9 \\
50 & 1.6 \\
70 & 1.4 \\
90 & 1.2 \\
\hline
\end{tabular}

In this case, tide-stage duration data may be applied directly to estimate the saltwater interface location. This type of analysis simulates a regulated streamflow condition and is useful in examining portions of the study reach that experience saline conditions for varied time periods. To examine possible changes in salinity distributions caused by withdrawals, streamflow may be reduced and interface locations calculated using the same tide-stage conditions.

\section{SALINITY DISTRIBUTIONS IN HILLSBOROUGH BAY}

To evaluate the effects of freshwater inflow on salinity distributions of Hillsborough Bay, fluctuations in freshwater inflow and salinity of the bay were analyzed. The effects of fluctuations in freshwater inflow from the Alafia River and Bullfrog Creek on salinity distributions of an area adjacent to these streams were also evaluated.

\section{Overall Salinity}

The primary source of saline water in Hillsborough Bay is the Gulf of Mexico. Water from the Gulf enters Tampa Bay and moves northward into Hillsborough Bay. The exchange of saltwater at the mouth of Hillsborough Bay is related to the rise and fall of tides in Tampa Bay. During high 


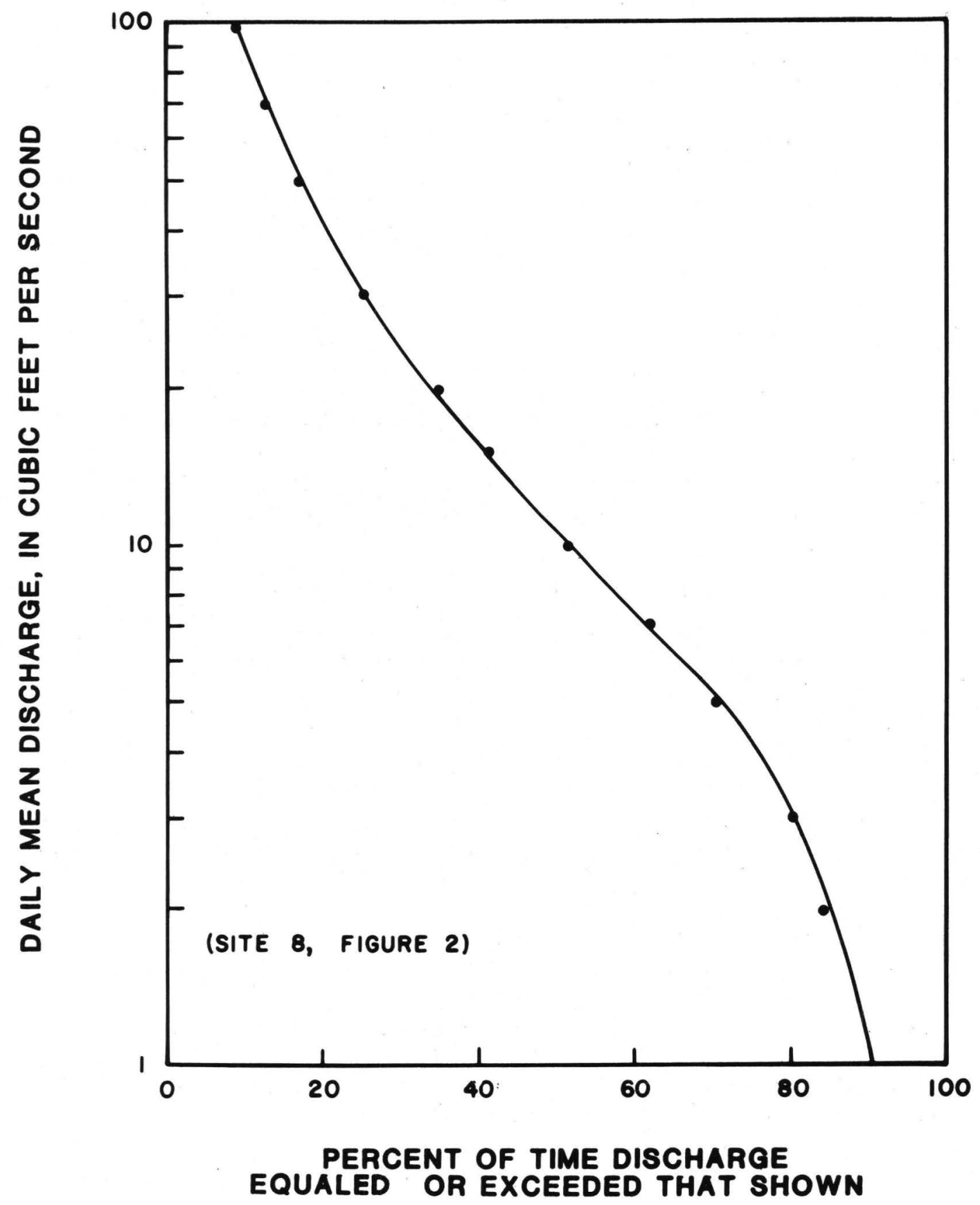

Figure 23.--Flow-duration curve for Bullfrog Creek near Wimauma for October 1956 to October 1958 and May 1977 to September 1979. 


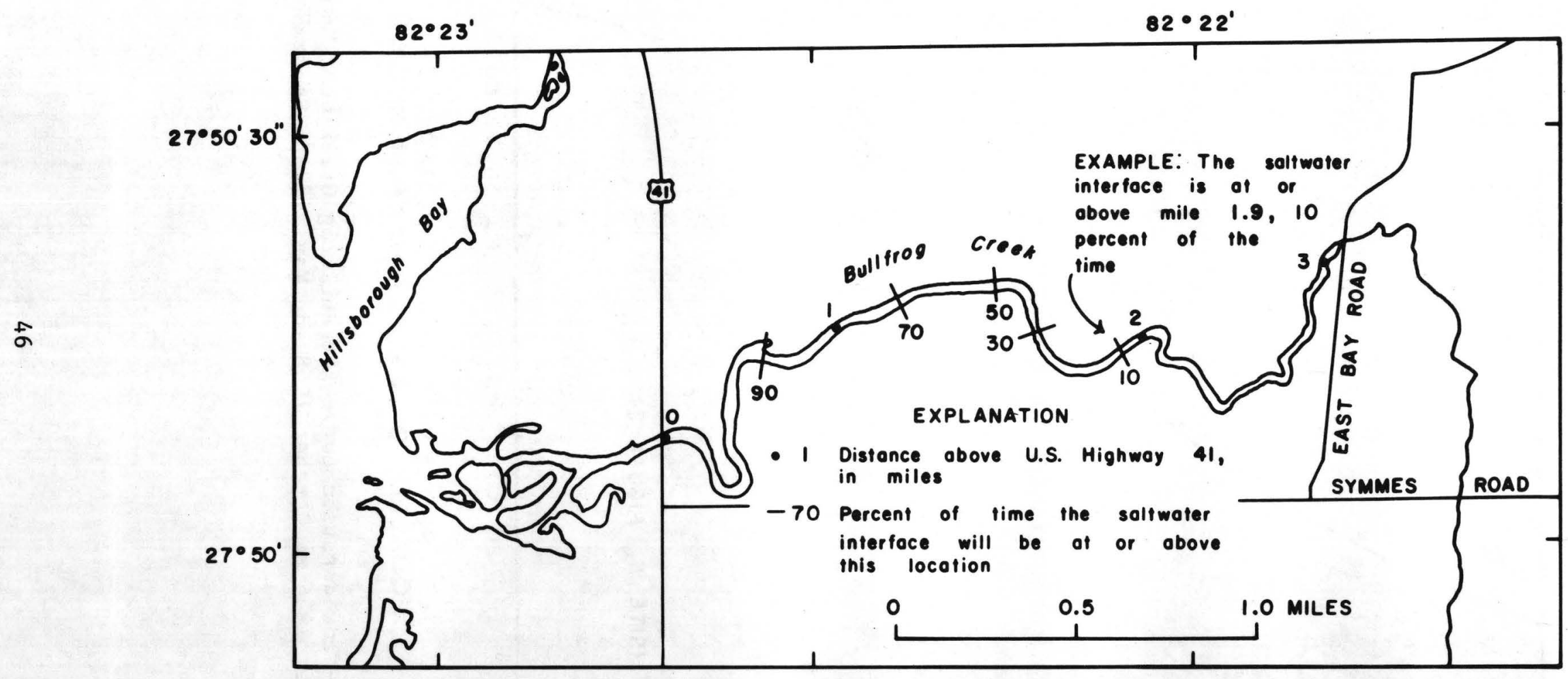

Figure 24.--Location and duration of the saltwater interface in Bullfrog Creek for constant streamflow and variable tide stage. 
tide, saltwater enters the bay; as the tide drops, a mixture of saltwater and freshwater drains to Tampa Bay. The total volume of water exchanged is called the tidal prism and is the difference between the volume of water in the bay at high and low tide. Salinity at the mouth of Tampa Bay is seldom less than 33 or 34 ppt (parts per thousand) because of its proximity to the Gulf. The salinity of Tampa Bay decreases shoreward due to freshwater inflow. The least saline water occurs in north Hillsborough Bay.

Overall salinity distributions in Tampa Bay and Hillsborough Bay vary with fluctuations in freshwater inflow. Monthly average conductivity (an indicator of salinity) in Hillsborough Bay and freshwater inflow for the period from June 1972 through June 1976 are shown in figure 25. A large freshwater inflow during July 1974 resulted in an average conductivity for the month of about 25,000 umho/cm. This wet period was followed by an extended dry period that resulted in an average conductivity in May 1975 of 47,000 umho/cm. As shown in figure 25, average conductivity decreases rapidly with increases in freshwater inflow, whereas salinity build up is a gradual process, working with tidal exchanges of saltwater during lowinflow periods. Flushing takes place rapidly due to large freshwater inflows and low storage capacity in the bay.

Freshwater inflow to the bay is derived primarily from the Hillsborough and Alafia Rivers. Two minor streams, Bullfrog Creek and Palm River, and Sulphur Springs, which discharges to the Hillsborough River, also contribute freshwater to the bay. The total freshwater inflow shown in figure 25 is the monthly mean discharge for the Hillsborough River (including Sulphur Springs), Alafia River, and Palm River. Other sources of freshwater, not included, are the city of Tampa wastewater treatment plant and ground-water inflow. A hydrograph of monthly mean discharge for the Alafia River is also shown in figure 25.

The Hillsborough River is normally the largest single source of freshwater inflow to Hillsborough Bay. The river is used for water supply by the city of Tampa and during low-flow periods may be totally diverted for municipal supply. In addition, water from Sulphur Springs is diverted for public supply during periods of low streamflow. Therefore, during dry periods, freshwater inflow to Hillsborough Bay is predominantly from the Alafia River, Bullfrog Creek, and Palm River. During these periods, flow from the Alafia River may represent greater than 60 percent of the freshwater inflow to Hillsborough Bay.

Salinity distributions in Hillsborough Bay during various inflow conditions are shown in figure 26. As indicated in figure 26A, when inflow is high, the least saline water occurs in the vicinity of the Hillsborough River. The large area between the 28,000 and 30,000 umho/cm conductivity lines may be caused by freshwater inflow from the Alafia River. During a period of average inflow (fig. 26B), the influence of the Hillsborough River decreases and salinity increases throughout the bay. For periods of low inflow (fig. 26C), the Alafia River is the major natural freshwater source in Hıllsborough Bay. Although conductivity levels in the bay are 


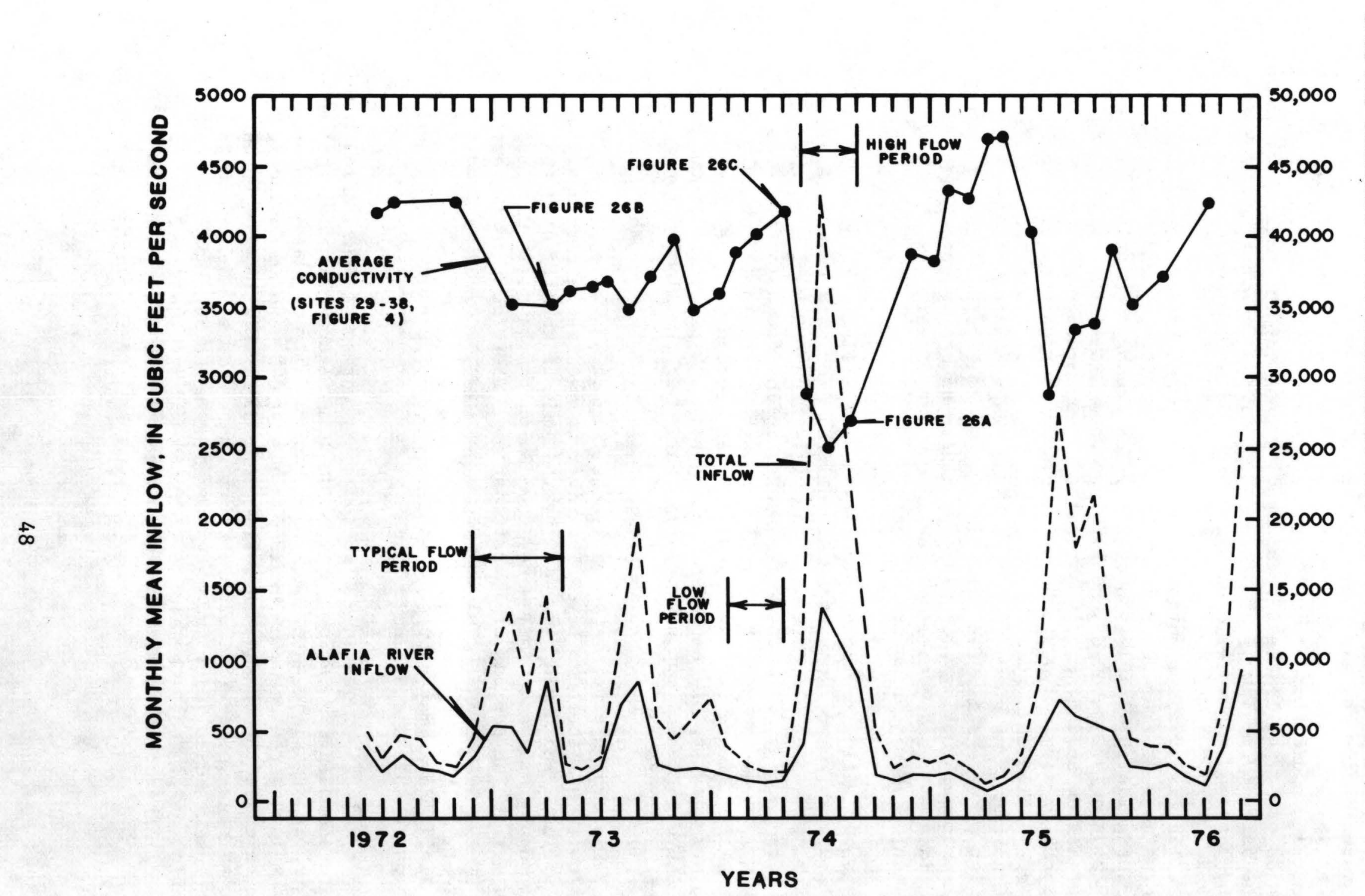

Figure 25.--Variation in the average conductivity of Hillsborough Bay, total monthly mean freshwater inflow to Hillsborough Bay, and the monthly mean inflow from the Alafia River, June 1972 through June 1976. 


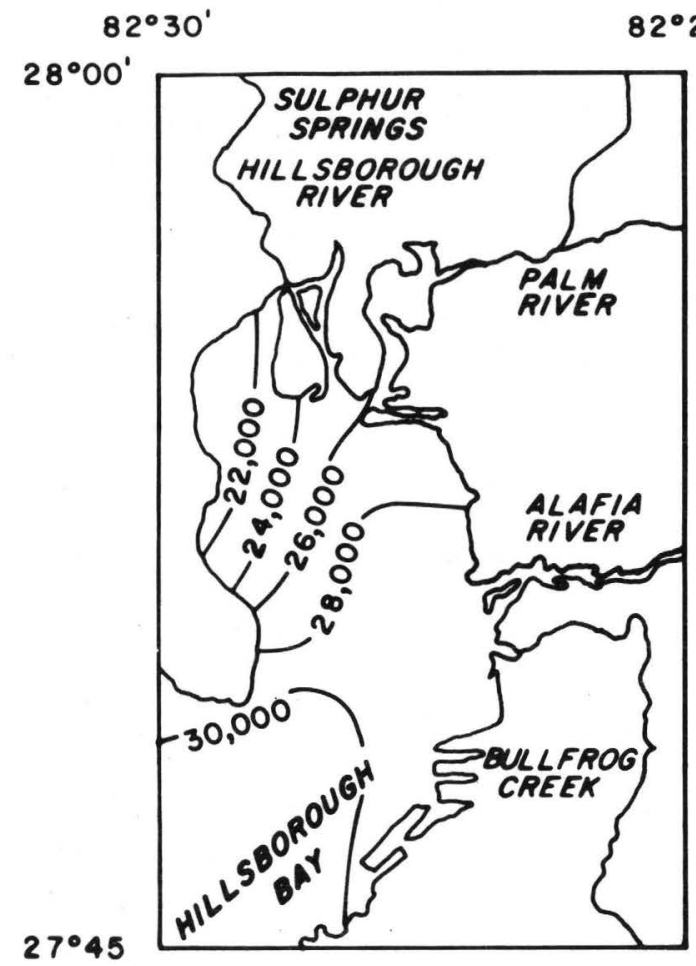

A. HIGH FLOW SEPTEMBER $\quad 16,1974$

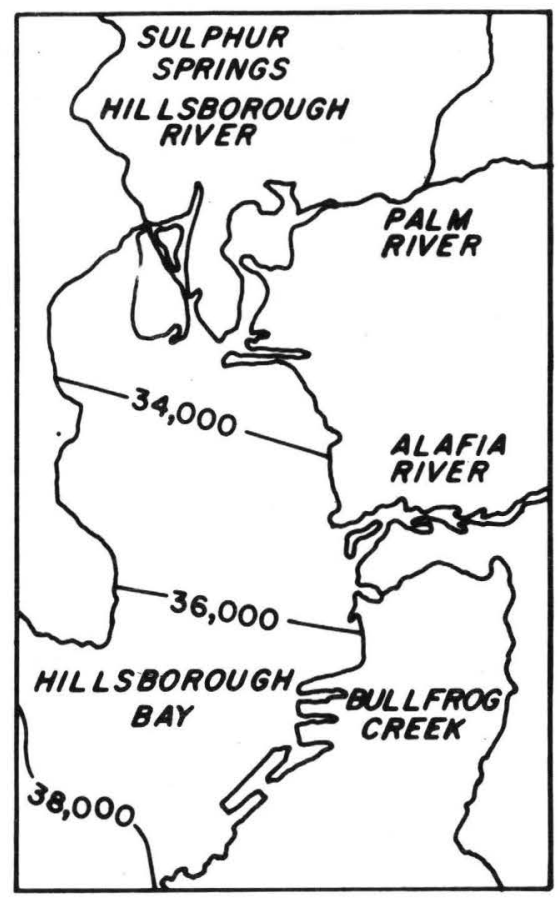

B. TYPICAL FLOW MAY 14,1973

EXPLANATION 44,000-

CONDUCTIVITY CONTOUR

In micromhos per centimever of

25 degrees celcius. (Interval is

2000 micromhos.)

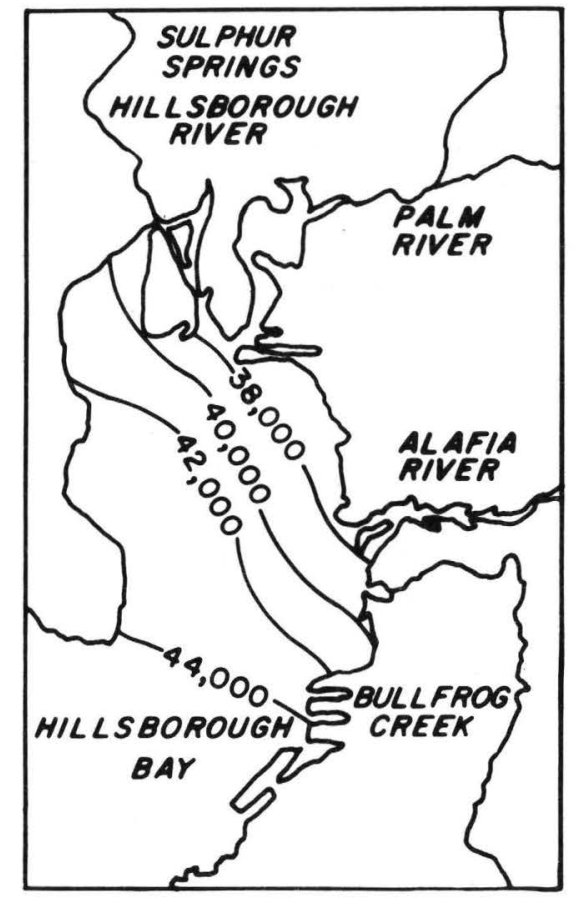

C. LOW FLOW JUNE 18,1974

Figure 26.--Variation in conductivity distributions in Hillsborough Bay for periods of high, typical, and low freshwater inflow. 
high, the influence of the Alafia River on salinity distributions can be seen. To determine the effect of fluctuations in freshwater inflow from the Alafia River and Bullfrog Creek on salinity distributions in the bay, a detailed analysis was made.

\section{Salt-Transport Mode1}

A numerical salt-transport model was applied to Hillsborough Bay in the vicinity of the Alafia River and Bullfrog Creek to examine the relationship between freshwater inflow and salinity distributions. This model enables long-term simulations that approximate stable conditions in the bay. By using a long-term simulation period and allowing salinity distributions in the bay to stablize for a given freshwater inflow condition, long-term effects of stream-flow regulation may be examined.

\section{Model Description}

The salt-transport model uses information on tidal circulation, background conductivity conditions, and freshwater inflow to determine salinity distributions. One principal assumption of the model is that complete vertical mixing exists throughout the estuary system, as is the case in Hillsborough Bay. The horizontal component of tidal circulation is the primary factor in the transport of saltwater from the Gulf to Hillsborough Bay and in dispersing the water within the bay.

The salt transport used in the model is based on residual flow, as determined from a tidal circulation model of Hillsborough Bay. Residual flow is the difference between the sums of discrete positive and negative tidal flows for a complete tide cycle. Use of daily residual flow rather than discrete flow within the tide cycle enables longer and more stable simulations to be made. In addition, use of residual flows reduces Hillsborough Bay to a steady-state system with a 1-day time step. The model cannot simulate dispersion of salt within the tide cycle, however, these effects are diminished by assuming complete horizontal as well as vertical mixing in each model cell.

The basic concept from which the model was developed is continuity or mass balance (Federal Water Pollution Control Administration, 1969). Two types of mass balance are included in the model. The first is a balance of residual tidal flow volumes and freshwater inflow volumes that are constant throughout the entire model simulation period. The second is balance of chemical constituents in the salinity portion of the model that change with each time step until stable levels in the model cells are reached.

Concentration of the input constituent for a single cell is computed by the mass balance equation as follows:

MASS IN CELL + MASS IN - MASS OUT = MASS REMAINING 
which can be expressed as:

$$
V_{C} K_{C}+\left(Q_{I} K_{I} d t+Q_{B} K_{B} d t\right)-Q_{C} K_{C} d t=V_{C} K_{C}{ }^{1}
$$

where $V_{C}=$ volume of the cell, in cubic feet,

$\mathrm{K}_{\mathrm{C}}=$ initial constituent concentration in the cell,

$\mathrm{Q}_{\mathrm{I}}=$ freshwater inflow to the cell, in cubic feet per day,

$\mathrm{K}_{\mathrm{I}}=$ constituent concentration of the freshwater inflow,

$\mathrm{dt}=\mathrm{time}$ interval used for determination of flow volume, in days,

$\mathrm{Q}_{\mathrm{B}}=$ saline boundary inflow to the cell, in cubic feet per day,

$\mathrm{K}_{\mathrm{B}}=$ constituent concentration of the saline boundary inflow,

$Q_{C}=$ outflow from the cell equal to $Q_{I}+Q_{B}$, in cubic feet per day,

and $\quad \mathrm{K}_{\mathrm{C}}{ }^{1}=$ constituent concentration in the cell after one time step, $\mathrm{dt}$.

By rearranging equation 6 in terms of dt and integrating both sides, the following solution equation is obtained:

$$
\frac{Q_{I} K_{I}+Q_{B} K_{B}}{Q_{C}}-\left(\frac{Q_{I} K_{I}+Q_{B} K_{B}}{Q_{C}}-K_{C}\right) e^{\left[(-t) \frac{\left(Q_{C}\right)}{V_{C}}\right]}=K_{C}{ }^{1}
$$

This equation determines the constituent concentration for each time step. Flow volumes and inflow concentrations remain constant for every time step. Constituent concentration within the cell, $\mathrm{K}_{\mathrm{C}}$, changes with every time step. The exponential term represents the amount of flow entering and leaving the cell $\left(Q_{C}\right)$ and the volume of the cell $\left(V_{C}\right)$. These terms determine how quickly the cell will reach stable concentration. A cell with a large volume $\left(V_{C}\right)$ will slow the mixing process and delay the time necessary to stablize. Increasing flow through the cell $\left(Q_{C}\right)$ will increase mixing and decrease the time required to stablize. By assuming time, $t$, equal to infinity, the exponential term becomes zero, thus, the final concentration in the cell for a given inflow and concentration condition is;

$$
\mathrm{K}_{\mathrm{C}}^{1}=\frac{\mathrm{Q}_{\mathrm{I}} \mathrm{K}_{\mathrm{I}}+\mathrm{Q}_{\mathrm{B}} \mathrm{K}_{\mathrm{B}}}{\mathrm{Q}_{\mathrm{C}}}
$$

The solution curve for equation 7 is a decaying exponential, beginning at the initial concentration $\left(\mathrm{K}_{\mathrm{C}}\right)$ and approaching the final concentration $\left(\mathrm{K}_{\mathrm{C}}{ }^{1}\right)$

This single cell approach was incorporated into a multicell model of Hillsborough Bay. This salt-transport model consisted of applying equation 7 to each model cell using a 1-day time step. This resulted in a number of equations and unknowns equal to the number of model cells that are solved using the Gauss-Seidel method of solving simultaneous equations. Using this model, intermediate time steps can be examined to determine the progression of changes in salinity distributions, as well as the final salinity distribution and the time necessary to reach stable conditions. 
The eight-cell salt-transport model was applied to Hillsborough Bay to determine changes in salinity distributions that may result from alteration of freshwater inflow. The area modeled and cell placement are shown in figure 27. Cell configuration was designed to fit physical features of the area. Freshwater inflow from the Alafia River is discharged into cell 1, with Bullfrog Creek discharging into cell 2. The principal criteria in boundary location was to maximize tidal flow across cell boundaries and keep circulation patterns in the bay well defined.

Salinity data for Hillsborough Bay were not available; therefore, conductivity was used in the model analysis as an indicator of salinity. Conductivity data were available from previous studies (Geotz and Goodwin, 1980), (Goodwin, 1974 and 1975). Other data required as input to the model were: volume of each cell, freshwater flow across the outer cell boundaries, tidal flow across inner and outer cell boundaries, conductivity of the freshwater inflow, tidal flow, and initial conductivity conditions.

Freshwater inflow from the Alafia River and Bullfrog Creek were adjusted using data from gaging stations (sites 5 and 8 , fig. 2), and a drainage area ratio to reflect flow from the entire basin (drainage area ratios used were 1.25 for the Alafia River and 1.40 for Bullfrog Creek). Freshwater inflows used for the simulations ranged from above average to extreme low flows, as summarized below.

\begin{tabular}{l|c|c}
\hline \multirow{2}{*}{ Streamflow condition } & \multicolumn{2}{c}{$\begin{array}{c}\text { Discharge at the mouth, } \\
\text { in cubic feet per second }\end{array}$} \\
\cline { 2 - 3 } & Alafia River & Bullfrog Creek \\
\hline 50 percent more than average daily & 682 & 78 \\
Average daily & 455 & 52 \\
50 percent of average daily & 228 & 26 \\
Average 30-day low flow & 81 & 9.2 \\
50 percent of average 30-day low flow & 40 & 4.6 \\
\hline
\end{tabular}

These discharges were converted to daily volumes for input to the model. As can be seen, emphasis was placed on below average streamflow conditions. Tidal-flow data were obtained from a tidal circulation model with a 500foot grid spacing of Hillsborough Bay (Goodwin, 1980). These tidal flows and average daily freshwater inflows from the Alafia River and Bullfrog Creek are summarized in figure 27. Tidal and inner cell flows shown in figure 27 are for average freshwater inflow conditions. Adjustment to flows for the Alafia River were made along the ship channel because of its influence on the flow direction. Fluctuations in the freshwater flow from Bullfrog Creek were made by adjusting outflow in cell 2. Tidal and freshwater flows into each cell must equal flows leaving the cell so that continuity is satisfied. This flow data is the mechanism by which constituent concentrations in each cell are distributed. 


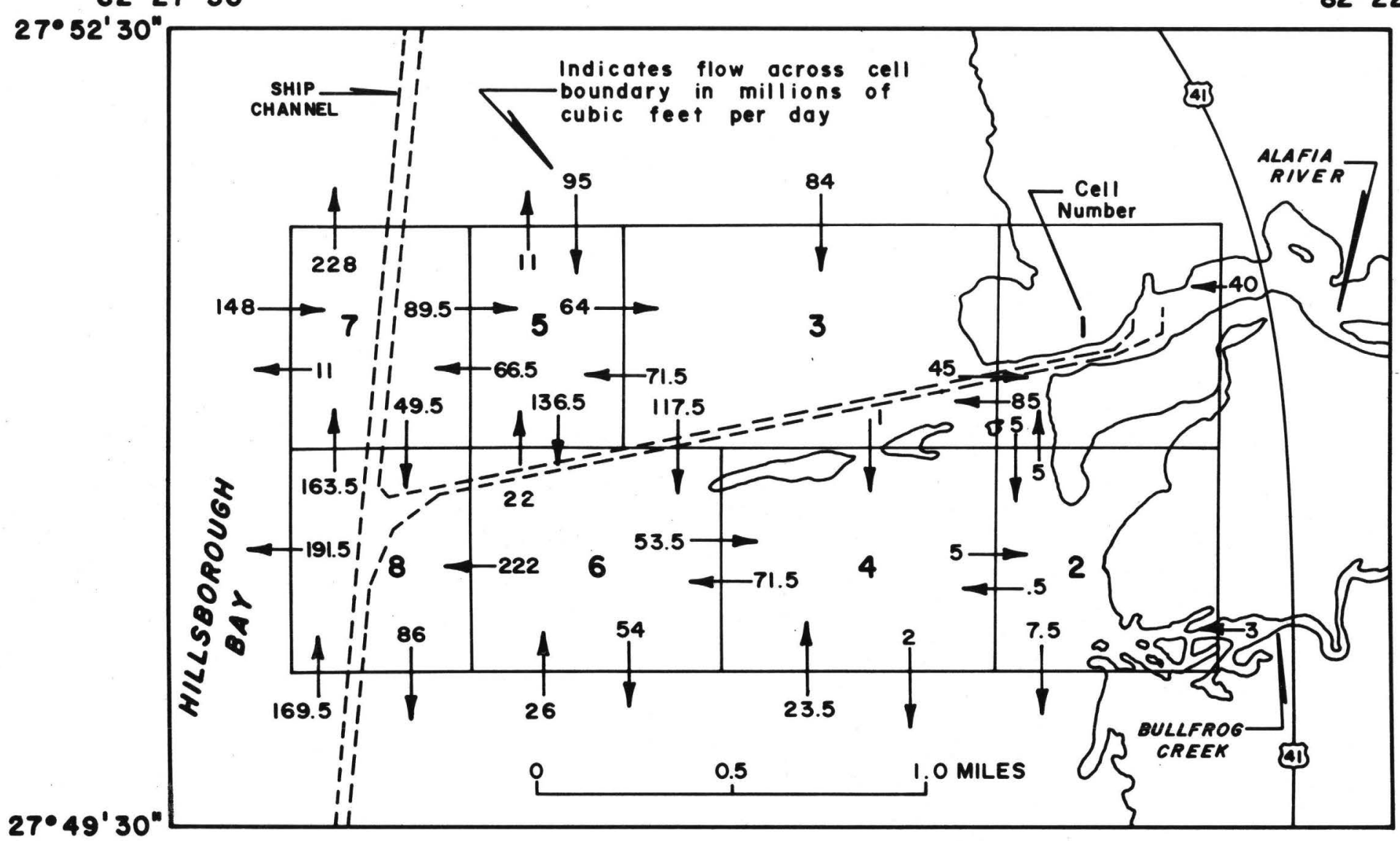
freshwater inflow conditions used in the salt-transport model. 
Conductivity input to the model for freshwater inflow was assigned a constant value of 1,000 umho/cm. Conductivity for tidal flows were assumed to be equal to the average conductivity of Hillsborough Bay for each freshwater inflow condition and are listed below. These conductivity values were estimated from a relation based on average conductivity and total freshwater inflow data for Hillsborough Bay shown in figure 25. A relation was also developed to estimate the total freshwater inflow to the bay, given streamflow in the Alafia River.

\begin{tabular}{l|c}
\hline \multicolumn{1}{c|}{ Streamflow condition } & $\begin{array}{c}\text { Input conductivity value } \\
\text { for tidal flows, } \\
\text { in micromhos per centimeter } \\
\text { at } 25^{\circ} \mathrm{C}\end{array}$ \\
\hline 50 percent more than average daily & 33,700 \\
Average daily & 36,400 \\
50 percent of average daily & 38,800 \\
Average 30-day low flow & 40,000 \\
50 percent of average 30-day low flow & 40,200 \\
\hline
\end{tabular}

Varying conductivity with respect to total freshwater inflow and inflow from the Alafia River approximates actual salinity conditions in the bay. Initial conductivity of each cell was assumed to be equal to final conductivity of the previous simulation. This assumption closely duplicates actual conditions with declining streamflow.

Model Results

Model simulations were made for each of the five freshwater inflow conditions, as summarized in table 3. Model runs were for a 30-day simulation period at which time each cell had reached a stable conductivity.

The relation between conductivity and freshwater inflow is shown in figure 28. This figure illustrates relative sensitivity of salinity to fluctuations in freshwater inflow. The largest fluctuation in conductivity occurs in cells 1 and 2, adjacent to the mouth of each stream. A reduction in freshwater inflow from the Alafia River from about 700 to $40 \mathrm{ft} / \mathrm{s}$ causes an increase in conductivity in cell 1 from 10,700 to 36,500 umho/ $\mathrm{cm}$. A similar change in conductivity occurs in cel1 2 for fluctuaions in streamflow from Bullfrog Creek. The least sensitive area modeled is cell 7, which exhibits a fluctuation in conductivity of only 8,500 umho/cm $(31,500$ to 40,000 umho/cm) for the five freshwater inflow conditions simulated. The effect of the ship channel on salinity distributions is also indicated in figure 28 and table 3 . Conductivity in cells 6 and 8 that are intersected by the ship channel is consistently lower than that in adjacent cells. 
Table 3.--Summary of simulated conductivities in each model cell for selected freshwater inflow conditions

\begin{tabular}{|c|c|c|c|c|c|}
\hline \multirow[b]{2}{*}{ Cell number } & \multicolumn{5}{|c|}{$\begin{array}{l}\text { Conductivity for indicated freshwater inflow } \\
\text { condition, in umho/ cm }\end{array}$} \\
\hline & $\begin{array}{l}\text { 50. percent } \\
\text { more than } \\
\text { average } \\
\text { flow }\end{array}$ & $\begin{array}{l}\text { Average } \\
\text { flow }\end{array}$ & $\begin{array}{l}50 \text { percent } \\
\text { less than } \\
\text { average } \\
\text { flow }\end{array}$ & $\begin{array}{l}\text { Average } \\
\text { 30-day } \\
\text { low flow }\end{array}$ & $\begin{array}{l}50 \text { percent } \\
\text { less than } \\
\text { average } 30- \\
\text { day low flow }\end{array}$ \\
\hline 1 & 10,700 & 15,400 & 23,500 & 33,100 & 36,500 \\
\hline 2 & 13,900 & 18,800 & 24,100 & 35,100 & 38,100 \\
\hline 3 & 23,200 & 27,800 & 33,400 & 38,000 & 39,200 \\
\hline 4 & 29,300 & 32,900 & 36,200 & 39,300 & 39,800 \\
\hline 5 & 29,600 & 33,300 & 36,900 & 39,400 & 39,900 \\
\hline 6 & 27,600 & 31,600 & 35,300 & 39,000 & 39,700 \\
\hline 7 & 31,500 & 34,700 & 37,700 & 39,700 & 40,000 \\
\hline 8 & 30,300 & 33,800 & 36,900 & 39,500 & 39,900 \\
\hline Boundary & 33,700 & 36,400 & 38,800 & 40,000 & 40,200 \\
\hline
\end{tabular}




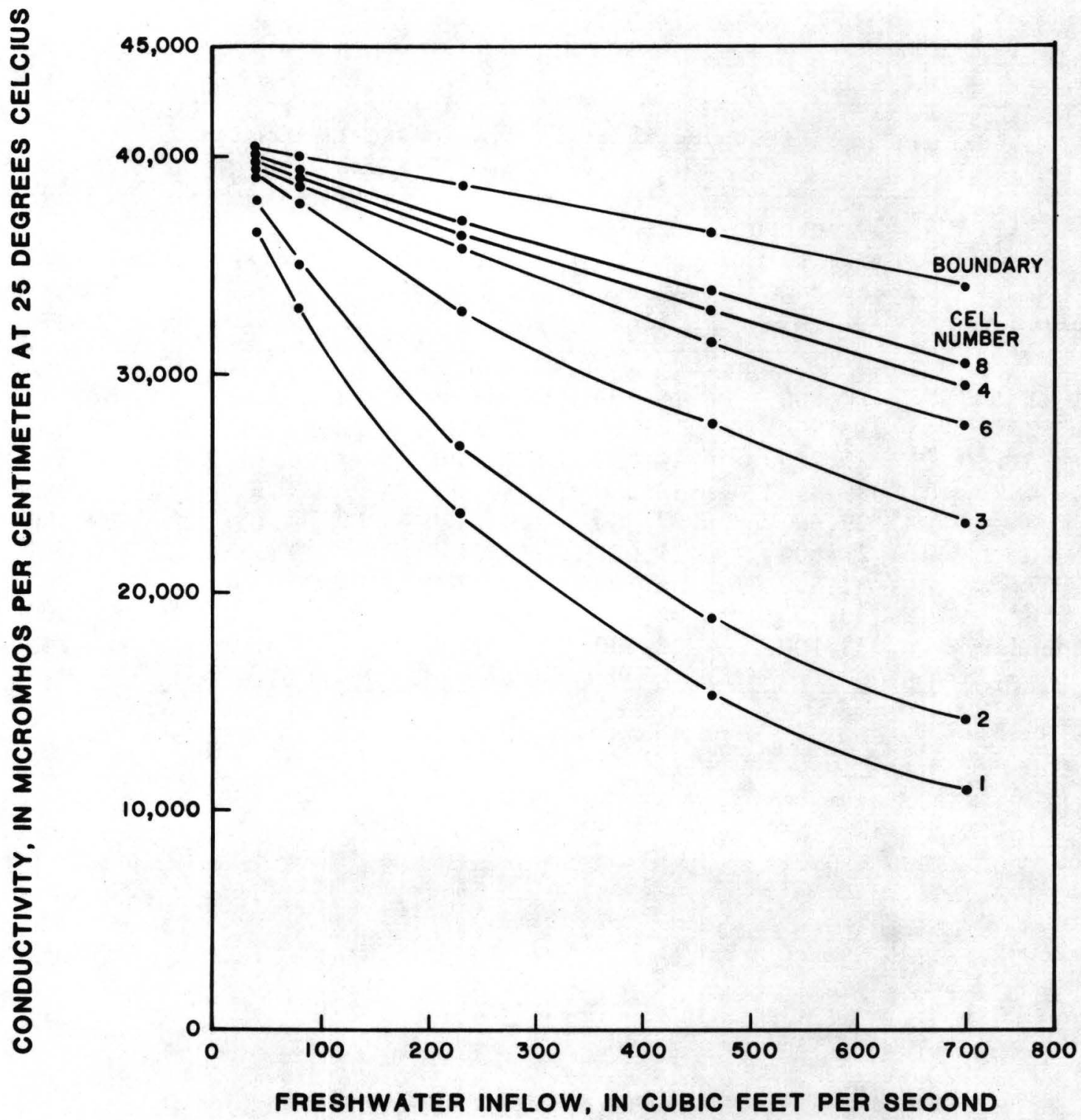

Figure 28.--Relation between conductivity in selected model cells and freshwater inflow. 
Results of the five simulations indicate that the closer the cell is to the mouth of the streams, the greater the effect freshwater inflow has on salinity of the cell. Large volumes of freshwater inflow reduces the conductivity of cells adjacent to the stream, whereas cells located towards the center of the bay experience little change. For below average streamflow conditions, the effect of variations in freshwater inflow on salinity is sma11.

\section{SUMMARY AND CONCLUSIONS}

This report examines changes in salinity distributions of the Alafia River, Bullfrog Creek, and Hillsborough Bay that may result from fluctuations in freshwater inflow. Changes in salinity which result from reductions in streamflow in the Alafia River and Bullfrog Creek are upstream encroachment of saltwater. In Hillsborough Bay, salinity concentrations in the vicinity of these streams are increased.

Data collection began in April 1978 and continued through September 1979. Data were collected on conductivity, streamflow, tide stage, waterquality, location of the saltwater interface for various streamflow, and tide-stage conditions. Conductivity, streamflow, tide stage, and chloride concentration data describe the chemical and physical characteristics of the saltwater wedge in the Alafia River and Bullfrog Creek. Conductivity is directly proportional to chloride concentration and was used as an indicator of salinity in this study. Movement of saltwater and flushing characteristics of both streams are described with respect to fluctuations in streamflow and tide stage. Flushing and large movements of saltwater are controlled by large fluctuations in streamflow, whereas small, frequent movements of saltwater are a function of daily fluctuations in tide stage. A discharge of about $3,500 \mathrm{ft}^{3} / \mathrm{s}$ will flush saltwater from the Alafia River, whereas a sustained streamflow of about $70 \mathrm{ft} / \mathrm{s}$ will flush Bullfrog Creek at mean tide stage. Vertical conductivity profiles indicate that an increase in freshwater inflow produces increased vertical stratification in both streams.

Relations were developed for determining the location and movement of the saltwater interface in the Alafia River and Bullfrog Creek using regression techniques. The equations define the location of the saltwater interface as a function of streamflow and tide stage. Due to differences in the physical characteristics of the streams, separate but similar methods were used to develop predictive equations. A geometric equation was produced for the Alafia River and two linear equations were developed for Bullfrog Creek. Streamflow proved to be the most significant parameter in each equation. The average standard error of estimate for the predictive equations ranged from 4.8 to 5.7 percent, and the average multiple correlation coefficient is 0.97 . The range of data for streamflow and tide stage in the Alafia River equation is from 76 to $250 \mathrm{ft} / \mathrm{s}$ and from -0.40 to 1.50 feet above ${ }^{\text {NGVD }}$ of 1929. For Bullfrog Creek, streamflow ranged from 12.3 to $71 \mathrm{ft}^{3} / \mathrm{s}$ and instantaneous tide stage ranged from -1.10 to 1.80 feet above the datum. 
Maximum inland movement of saltwater in the Alafia River for zero streamflow and for a mean daily tide stage of 0.64 feet above NGVD of 1929 was estimated to be approximately 10.5 miles upstream from U.S. Highway 41. The range of the Alafia River predictive equation extended from 4.6 miles upstream of U.S. Highway 41 to the point of maximum saltwater encroachment at zero streamflow. The portion of stream reach for which the Bullfrog Creek equations apply is from 0.25 to 2.9 miles upstream from U.S. Highway 41.

Mean location of the saltwater interface in the Alafia River for the 7-, 14-, 30-, 60-, 90-, and 120-day, 2-year low flows at mean tide stage ranged from 9.0 to 5.9 miles above U.S. Highway 41 . A 25 percent reduction in the 120-day, 2-year discharge would result in an upstream movement of the saltwater interface of about $0.8 \mathrm{mile}$, whereas a 75 percent reduction would cause an upstream movement of about 3.2 miles. This would be for instream withdrawals with no storage available and not considering minimum streamflow requirements. To meet Southwest Florida Water Management District minimum in streamflow requirements and still withdraw from the Alafia River on a regular basis during drought periods, storage is needed. For a 20-year, 90-day drought, a withdrawal of $24 \mathrm{Mgal} / \mathrm{d}$ could not be sustained with a storage of $2,000 \mathrm{Mgal}$ if the existing minimum streamflow requirements are to be met. By reducing minimum flow requirements by 50 percent, a $24 \mathrm{Mgal} / \mathrm{d}$ withdrawal could be met for a 20-year, 90-day drought assuming 2,000 Mgal of storage at the beginning of the drought period. This reduction in minimum flow requirements would cause saltwater to be located 0.4 mile further upstream than the full compliance condition.

A duration analysis of the Alafia River and Bullfrog Creek indicates the percent of time the saltwater interface will be located at points in the streams for given discharge and tide-stage conditions. In the Alafia River for a constant tide stage of 0.64 foot above NGVD of 1929, the saltwater interface is estimated to be located 4.2 miles above U.S. Highway 41 seventy percent of the time and 8.2 miles above U.S. Highway 41 only 10 percent of the time. In Bullfrog Creek for a constant discharge of 18.5 $\mathrm{ft}^{3} / \mathrm{s}$, the saltwater interface was estimated to be located 0.8 mile above U.S. Highway 41 ninety percent of the time and 1.9 miles above U.S. Highway 41 only 10 percent of the time.

Salinity distributions in Hillsborough Bay vary with fluctuations in freshwater inflow. Average conductivity in the bay ranged from 25,000 to 47,000 umho/cm for wet and dry periods. Flushing of the bay is rapid due to large freshwater inflows and low storage capacity, whereas salinity buildup is a gradual process working with tidal exchanges during low-flow periods. The Hillsborough River is the largest source of freshwater during wet periods, and the Alafia River contributes a large percentage of freshwater inflow during low-flow periods. Salinity distributions in the bay shift depending on the source and volume of freshwater inflow.

Salinity distributions of Hillsborough Bay in the vicinity of the Alafia River and Bullfrog Creek were evaluated using a salt-transport model for freshwater inflow conditions ranging from 50 percent more than average daily to 50 percent below the 30-day low flow. The maximum range 
in conductivity was for an area adjacent to the mouth of the Alafia River, 10,700 to 36,000 umho/ cm, whereas the conductivity of an area near the center of the bay ranged from 31,500 to $40,000 \mathrm{umho} / \mathrm{cm}$. Model results indicate that freshwater inflow from the Alafia River and Bullfrog Creek has the greatest effect on areas closest to the mouth of these streams during periods of above average inflow.

\section{SELECTED REFERENCES}

Barr, A. J., Goodnight, J. H., Sal1, J. P., and Helwig, J. T., 1976, A user's guide to SAS 76: SAS Institute, Inc., Raleigh, North Carolina, $329 \mathrm{p}$.

Bunce, R. E., and Hetling, L. J., 1969, A steady segmented estuary model: Federal Water Pollution Control Administration, Middle Atlantic Region, Technical Paper No. 11, Charlottesville, Virginia, 201 p.

Bush, P. W., 1973, Salt-water movement in the Lower Withlacoochee RiverCross-F1orida Barge-Canal Complex: U.S. Geologica1 Survey WaterResources Investigations 5-72, 32 p.

Coble, R. W., 1973, The Anclote and Pithlachascotee Rivers as water-supply sources: Florida Bureau of Geology Map Series No. 61.

Cohen, Bernard, and McCarthy, L. T., Jr., 1962, Salinity of the Delaware Estuary: U.S. Geological Survey Water-Supply Paper 1586-B, p. 47.

Cronin, E. L., 1975, Circulation and salinity distribution in the Rio Guayas Estuary, Ecuador, in Estuarine Research Volume II, Geology and Engineering: New York, Academic Press, Inc., p. 345-363.

Cummings, T. R., 1968, Salt-water encroachment in the South Edisto River Estuary, South Carolina: U.S. Geological Survey Water-Supply Paper 1586-I, 19 p.

Dames \& Moore, 1974, Hydrologic assessment of the Alafia and Little Manatee Rivers, Southwest Florida Water Management District: Consultants report in files of the Southwest Florida Water Management District.

Environmental Quality Laboratory, Inc., 1979, Hydrobiological monitoring, January 1976 through October 1978, lower Peace River and Charlotte Harbor: Consultants report in files of Southwest Florida Water Management District, $124 \mathrm{p}$.

Federal Water Pollution Control Administration, 1969, Problems and management of water quality in Hillsborough Bay, Florida: U.S. Department of the Interior, $88 \mathrm{p}$.

Giese, G. L., Wilder, H. B., and Parker, G. G., Jr., 1979, Hydrology of major estuaries and sounds of North Carolina: U.S. Geological Survey Water-Resources Investigations 79-46, $175 \mathrm{p}$.

Glover, K. C., 1978, A computer program for simulating loads in streams: U.S. Geological Survey Open-File Report 78-884, 31 p. 
Goetz, C. L., and Goodwin, C. R., 1980, Water quality of Tampa Bay, Florida: June 1972 - May 1976: U.S. Geological Survey Water-Resources Investigations $80-12,58 \mathrm{p}$.

Goodwin, C. R., 1977, Circulation patterns for historical, existing, and proposed channel configurations in Hillsborough Bay, Florida: 24th International Navigation Congress, Leningrad, $13 \mathrm{p}$.

1980, Preliminary simulated tidal flow and circulation patterns in Hillsborough Bay, Florida: U.S. Geological Survey Open-File Report 80-1021, 7 p.

Goodwin, C. R., Rosenshein, J. S., and Michae1is, D. M., 1974, Water Quality of Tampa Bay, Florida, dry-weather conditions, June 1971:

U.S. Geological Survey Open-File Report FL-74026, 85 p.

1975, Water quality of Tampa Bay, Florida, wet-weather conditions, October 1971: U.S. Geological Survey open-file report FL-75005, 88 p.

Grantham, R. G., and Sherwood, C. B., 1968, Chemical quality of waters of Broward County, Florida: Florida Geological Survey Report of Investigation $51,52 \mathrm{p}$.

Gross, G. M., 1967, Oceanography: Charles E. Merrill Books, Inc., Columbus, Ohio, $135 \mathrm{p}$.

Harder, J. A., 1977, Predicting estuarine salinity from river inflows: American Society of Civil Engineers, Journal of the Hydraulics Division v. 103, no. HY8, p. 877-888.

Hem, J. D., 1970, Study and interpretation of the chemical charcteristics of natural water: U.S. Geological Survey Water-Supply Paper 1473, $363 \mathrm{p}$.

Hughes, J. L., 1979, Salt-water-barrier line in Florida, concepts, considerations, and site examples: U.S. Geological Survey Water-Resources Investigations $79-75,29$ p.

Ippen, A. T., 1966, Estuary and coastline hydrodynamics, engineering societies monographs: New York, McGraw-Hill, 744 p.

James, M. L., Smith, G. M., and Wolford, J. C., 1968, Applied numerical methods for digital computation with Fortran: International Textbook Company, Scranton, Pennsylvania, 514 p.

Johnson, Lamar, 1963, A basic plan of Alafia River: Lamar Johnson, Consulting Engineer, Lake Wales, Florida.

Keighton, W. B., 1966, Fresh-water discharge salinity relations in the tidal Delaware River: U.S. Geological Survey Water-Supply Paper 1586-G, 16 p.

Ketchum, B. H., 1951, The exchanges of fresh and salt waters in tidal estuaries: Journal of Marine Research, v. 10, p. 18-37.

Leach, S. D., 1978, Source, use, and disposition of water in Florida, 1975: U.S. Geological Survey Water-Resources Investigations 78-17, 90 p.

Leach, S. D., and Grantham, R. G., 1966, Salt-water of the Miami River and its tributaries, Dade County, Florida: Florida Geological Survey Report of Investigation 45, $36 \mathrm{p}$. 
Menke, C. G., Meredith, E. W., and Wetterha11, W. S., 1961, Water resources of Hillsborough County, Florida: Florida Geological Survey Report of Investigation $25,101 \mathrm{p}$.

McDowe11, D. M., and O'Connor, B. A., 1977, Hydraulic behavior of estuaries: New York, John Wiley, 292 p.

Miche1, J. F., Work, R. C., Rose, F. W., and Rehrer, R. G., 1975, A study of the effect of fresh water withdrawal on the lower Peace River, DeSoto County, Florida: University of Miami, Rosenstiel School of Marine and Atmospheric Science, Miami, Florida, 99 p.

Morris, A. W., Mantoura, R. F. C.. Bale, A. J., and Howlend, R. I. M., 1978, Very low salinity regions of estuaries: important sites for chemical and biological reactions: Nature, v. 274, no. 5672, p. 678-680.

National Oceanic and Atmospheric Administration, 1979, Tide tables, 1979 high and low water predictions, east coast of North and South America including Greenland: U.S. Department of Commerce, 293 p.

National Ocean Survey, U.S. Coast and Geodetic Survey, 1957, Map of west coast southern part of Hillsborough Bay, Florida: U.S. Department of Commerce map, scale 1:10,000.

Parker, G. G., 1976, Feasibility of a dam and reservoir for water-supply purposes and potential aquifer recharge, Bullfrog Creek, southeast Hillsborough County, Florida: Southwest Florida Water Management District, $10 \mathrm{p}$.

Parker, G. G., Ferguson, G. E., Love, S. K., and others, 1955, Water resources of southeastern Florida: U.S. Geological Survey Water-Supply Paper 1255, 965 p.

Partheniades, Emmanue1, Dermisis, Vassilios, and Metta, A. J., 1980, Graphs for saline wedges in estuaries: American Society of Civil Engineers, Civil Engineering Magazine, p. 90-92.

Prych, E. A., Haushild, W. L., and Stoner, J. D., 1976, Numerical model of the salt-wedge reach of the Duwamish River estuary, King County, Washington: U.S. Geological Survey Professional Paper 990, 34 p.

Reid, G. E., 1961, Ecology of inland waters and estuaries: New York, D. Van Nostrand Company, 375 p.

Rigter, B. P., 1973, Minimum length of salt intrusion in estuaries: Journal of the Hydraulics Division, Proceedings of the American Society of Civil Engineers, v. 99, no. HY9, p. 1475-1496.

Riley, J. P., and Skirrow, G., 1965, Chemical oceanography: New York, Academic Press, 712 p.

Robertson, A. F., 1978, Flood profiles of the Alafia River, west-central Florida, computed by step-backwater method: U.S. Geological Survey Water-Resources Investigations 77-74, $21 \mathrm{p}$.

Santos, J. F., and Stoner, J. D., 1972, Physical, chemical, and biological aspects of the Duwamish River estuary, King County, Washington, 1963-67: U.S. Geological Survey Water-Supply Paper 1873-C, 74 p. 
Schroeder, W. W., 1978, Riverine influence on estuaries, a case study, in Estuarine Interactions 1978: New York, Academic Press, Inc., p. 347-364.

Southwest Florida Water Management District, 1974, The Laws, Rules, and Regulations of the Southwest Florida Water Management District, Chapter 373.042 and Supplement No. 73, Chapter 16J-0.15 $(1+2)$.

Thomann, R. V., 1963, Mathematical model for dissolved oxygen: American Society of Civil Engineers, Journal of the Sanitary Engineering Division, v. 89, SA5, p. 1.

Tiphane, Marcel, 1962, Tables de Determination de la Salinite De L'Ean De Mer par conductivite Electrique, Jacques St. Pierre Centre de Statistique et de Calcul, Universite de Montreal, Montreal, Quebec, Canada.

U.S. Army Corps of Engineers, 1974, Draft environmental impact statement, Tampa Harbor project: U.S. Army District Engineer, Jacksonville, Florida, 220 p.

1972, Special studies on Tampa Harbor, Florida: U.S. Army District Engineer, Jacksonville, Florida.

U.S. Geological Survey, 1972-1976, 1978, 1979, Water resources data for Florida.

Weige1, R. L., 1964, Oceanographical engineering: Prentice Hall, Inc., Englewood Cliffs, New Jersey, p. 299-330.

Williams, Jerome, Higginson, J. J., and Rohrabough, J. D., 1968, Sea and air, the naval environment: U.S. Naval Institute, Annapolis, Maryland, p. 309-322. 